\title{
MADE/MAID IN THE MEDIA: NARRATIVE DISCOURSES SURROUNDING FILIPINA NANNIES IN THE LIVE-IN CAREGIVER PROGRAM
}

\author{
by \\ Holly Dae Edejer, BA, University of Toronto, 2010 \\ A Major Research Paper \\ presented to Ryerson University \\ in partial fulfillment of the requirements for the degree of \\ Master of Arts \\ in the Program of \\ Immigration and Settlement Studies
}

Toronto, Ontario, Canada, 2014

(C) Holly Dae Edejer 2014 
I hereby declare that I am the sole author of this Major Research Paper. This is a true copy of the MRP, including any required final revisions, as accepted by my examiners.

I authorize Ryerson University to lend this MRP to other institutions or individuals for the purpose of scholarly research.

I further authorize Ryerson University to reproduce this MRP by photocopying or by other means, in total or in part, at the request of other institutions or individuals for the purpose of scholarly research.

I understand that my MRP may be made electronically available to the public.

Holly Edejer 


\title{
MADE/MAID IN THE MEDIA: \\ Narrative Discourses Surrounding Filipina Nannies in the \\ Live-In Caregiver Program
}

(C) Holly Dae Edejer

Master of Arts 2014

Immigration and Settlement Studies

Ryerson University

\begin{abstract}
This paper explores the various narratives and media representations surrounding Filipinas in Canada's Live-In Caregiver Program. This study draws upon existing scholarship in global migration of (gendered, racialized, and class-based) domestic labour, as well as theories of postcolonialism and media studies. Using critical discourse analysis, the content of 132 news articles from 1988 to 2014 in the Toronto Star are coded and discussed. The five main categories in which these Filipina live-in caregivers - 'or Filipina nannies' - are constructed are identified as foreigners, mothers, workers, victims, and activists. The research findings suggest that representations of Filipina live-in caregivers are framed by notions of difference and social hierarchy in Canada's most widely disseminated newspaper. Thus this newsprint media discourse reproduces the subaltern status and dual in/visibility of this minority group in Canadian society.
\end{abstract}

Key Words:

Canadian Immigration; Critical Discourse Analysis; Filipina Nanny; Live-In Caregiver Program; Newsprint Media 


\section{Acknowledgements}

I would like to thank Dr. Hyacinth Simpson, my ISS faculty advisor and MRP supervisor, for her incredible support and guidance throughout the entire MRP process. Her insight and feedback on my work have challenged me to become a more creative and critical academic thinker. I am extremely grateful for what I have gained from the experience, and am proud of the quality of the finished MRP thanks to her supervision.

I would also like to thank my second reader for this paper, Dr. Harald Bauder, for his thoughtful comments and recommendations that helped shape this paper to its completed form.

Last but not least, thank you to the rest of the faculty and my fellow students involved with the Ryerson University Immigration and Settlement Studies Program. It has been an intense and challenging year, but always an absolute pleasure to be surrounded by such supportive and talented people. 


\section{CONTENTS}

\section{INTRODUCTION}

1.1 Research Question and Justification $\quad 1$

1.2 Research Scope $\quad 5$

1.3 Filipino Immigration to the GTA in Canada 6

1.4 The Live-In Caregiver Program (LCP) 7

1.5 Conceptual Framework 9

\section{LITERATURE REVIEW}

2.1 The Globalization of Domestic Labour 11

2.2 Blurring Private and Public Spheres of Work and Home 15

2.3 Transitioning from Temporary Foreign Worker to Permanent Resident 18

2.4 Family Separation and Reunification 19

2.5 Narrative Discourses (Personal and Public) 21

\section{RESEARCH METHOD}

3.1 Data Source: The Toronto Star 25

3.2 Data Collection Process 26

3.3 Thematic/Categorical Coding 27

3.4 Data Analysis: Critical Discourse Analysis (CDA) 28

3.5 Study Limitations $\quad 30$

4. RESEARCH ANALYSIS

4.1 Findings: Major Narrative Themes and Categories 32

4.2 Filipina Nannies in the LCP as Foreigners $\quad 34$

4.3 Filipina Nannies in the LCP as Mothers 36

4.4 Filipina Nannies in the LCP as Workers $\quad 42$

4.5 Filipina Nannies in the LCP as Victims $\quad 45$

4.6 Filipina Nannies in the LCP as Activists $\quad 50$

5. CONCLUSION

5.1 Discussion and Implications $\quad 55$

5.2 Recommendations $\quad 56$

5.3 Future Research 58

6. APPENDIX

6.1 News Articles in the Toronto Star Coding Sheet 62

\section{REFERENCES}

7.1 List of Toronto Star Articles Cited 94

7.2 Academic References 99 


\section{List of Appendices}

Appendix 1. News Articles in the Toronto Star Coding Sheet 


\section{INTRODUCTION}

\subsection{Research Question and Justification}

The focus of this research is an investigation of the narrative discourses generated in the Toronto Star between 1992 and the present about Filipina migrant workers in the Live-in Caregiver Program (LCP) in Toronto. The goal is to determine the extent to which this popular newspaper participates in perpetuating, challenging, and or problematizing representations of Filipina caregivers for Canadian readers, and how such representations may reproduce structures of inequality. To achieve this goal, all relevant news content within this period is examined using a critical discourse analysis (CDA) approach; and the findings derived from applying a CDA framework are further illuminated by existing scholarship in the areas of international (gendered) migrant labour, postcolonial studies, and media studies - especially where these critical frameworks provide insight into the social and political ramifications of the caregivers' race, gender, nationality/cultural identity, and migrant status for their experience in Canada.

The LCP is an immigrant-class stream comprised predominantly of Filipinas, women of colour recruited by the Canadian government for Canadian employers in home-based jobs to care for children and the elderly. Such jobs have not only been traditionally spurned by Canadians, but are also largely unregulated and undervalued. Although labour market trends and the ongoing demand for live-in caregivers indicate that many Canadians view the work of live-in caregivers as contributing to the efficiency of family units and thus the improved productivity of the caregivers' employers in the workforce (and also, as a consequence, to a more vibrant economy), the social perception and treatment of the caregivers and their work in the home do not always accord with this reality. Arguably, this 
gap between social perception, treatment, and reality occurs in part because such jobs are filled by non-citizen, migrant labourers who remain marginal within the nation's sociopolitical and economic spheres. That marginality is not only a function of the workers' status but also of the low wages they earn and the often precarious conditions in which they work.

These subaltern workers' marginality is further exacerbated by the fact that they are women of colour from a poor country that is of lesser status in relation to Canada in the global north-south divide. It is not too far-fetched to suggest that the LCP - from how and where labour for the program is sourced, to the conditions of recruitment, to how the program currently operates - replicates "long-lasting patterns of inequality in power, wealth and cultural influence that grew historically out of European and North American imperialism" (Connell, 2007, p. 212). In other words, the LCP displays some of the same problems of cross-cultural, cross-ethnic labour relations that both postcolonial scholars and critics of contemporary global migrant labour have identified as relevant in their fields. For example, as Baldoz (2011) has pointed out, the recruitment of migrant labour from nations in the global south enlarges the territorial borders of the receiving nation as the latter is able to benefit from the migrants' labour while restricting their access to full citizenship rights. For instance, domestic female workers of colour from sending nations (such as the Philippines) perform caregiving work for wealthier, often white, women in receiving nations (Nakano Glenn, 1992). Thus it would seem that the LCP functions as a political legacy of race and colonialism in its rendering of its subjects invisible and unable to participate fully in Canadian society. 
Additionally, while their political and social marginality as migrant workers render Filipinas in the LCP invisible, their racial/ethnic and cultural "difference" from nonracialized Canadians can often make them visible, but in ways that underscore their marginality. It is this simultaneous and paradoxical in/visibility at the heart of the experience of Filipinas in the LCP that informs certain dominant representations and "common sense" knowledge about them (and migrant workers in general), and which can reinforce these women's lack of power within Canadian society.

As an ideological state apparatus (Althusser, 1970), mainstream print (and digitized) media such as the Toronto Star are often invested in reproducing and reinforcing the ideologies of the ruling class, thereby maintaining structures of power and production that benefit those in positions of power. As Althusser further argued, ideological state apparatuses exert their influence not through direct force and control (as is the case with repressive state apparatuses) but through coercion and via symbols and codes that serve to naturalize discourses that maintain the status quo.

Hall (2007) defines discourse as "a group of statements which provide a language for talking about [...] a particular kind of knowledge about a topic" (p. 57). The media is one of the main channels through which discourses are created and disseminated to the public. The particular language and imagery used in the media in any given instance will convey particular meanings that in turn support certain ideologies (Hall, 1997). These underlying ideologies become so deeply ingrained that they often escape popular critical scrutiny. Conducting a content analysis of a newspaper like the Toronto Star enables explicit awareness of the real power of media discourse, identifies the language and images used in relation to Filipina caregivers, and decodes the ideologies underpinning LCP discourse. 
The purpose of this study, therefore, is to determine what kinds of discourses and narratives about Filipina live-in caregivers are naturalized in the news items about Filipina caregivers that have appeared on a regular basis in The Toronto Star over a period of twenty-two years. For example, what kinds of identity constructions predominate in the newspaper vis-à-vis the Filipina caregiver presence? How are those constructions codified? And what purposes do they serve? These questions are important as media discourses help shape people's belief systems, and the naturalization of certain discourses may thus impact the real lives of live-in caregivers.

In uncovering and understanding the processes through which certain ideas about 'the Filipina nanny' (this term is often used in news items to refer to live-in caregivers whether or not their home-care work involves child care) take shape in the Canadian cultural psyche, it becomes possible to deconstruct the associated narratives and discourses. There is potential for social change in such an act of deconstruction as it draws attention to the language (particular images) and other signifiers at the base of certain constructions, reveals their contingencies, and so opens the door for other, more beneficial, diverse, and inclusive representations.

In addition to the questions posed above, the main research questions of this project include: What are the prominent narrative components surrounding popular discourses of the workers of the LCP in Toronto (i.e., in Canada's most widely read newspaper, the Toronto Star)? What are the ideological underpinnings present in these discourses, and how do they fit together to create a dominant framework through which the newspaper's Canadian readers understand live-in caregivers in relation to themselves? 
There are several reasons this study is relevant to the ongoing production of knowledge on immigration and settlement in Canada: (1) it adds to already existing literature on the Live-in Caregiver Program by applying a new critical lens to the analysis of the subject; (2) it provides a case study and investigation of Canadian newsprint media coverage of a particular group of temporary foreign workers, which may help guide the process of assessing how other immigrant and minority groups are represented in media; and (3) it leads to a process of questioning how and why particular assumptions and discourses exist in the larger context of Canadian immigration and settlement, in the media, political realm, and elsewhere.

\subsection{Research Scope}

As previously indicated, this research paper's specific focus is an analysis of the representation of Filipina live-in caregivers in the Toronto Star. While some generalizations could later emerge or be made regarding the narratives of live-in caregivers produced in the Toronto Star and those produced in other major Canadian newspapers (such as The Globe and Mail and the National Post) if similar discourse analysis were to be done on the content of these other news media sources in the future, the data analysis provided in this research paper is specific to the articles in the Toronto Star. As such, the results obtained and discussed are specific to a particular data sample. Additionally, while this paper may draw upon the background of globalized Filipina labour migration as domestic caregivers, this paper is limited specifically to the LCP in Canada. Furthermore, this paper only concentrates on Filipina workers in the LCP, who comprise the vast majority of workers in this immigration program. In addressing the stated subject, the analysis does not seek to homogenize the experiences of live-in caregivers: it is not expected that this research paper 
can encompass the diversity of individual experiences Filipina caregivers may have in the LCP, but only serves to address the representations (as they appear in the collected data source) attributed to their identity and how their stories are told in a mainstream news source.

\subsection{Filipino Immigration to Toronto in Canada}

The Philippines has experienced a history of multiple colonization and sociopolitical exploitation, from close dealings with Chinese trade (900-1521) and Spanish colonialism (1521-1898) to American occupation (1898-1946) and Japanese invasion during World War Two (1942-1945). This history is significant in rooting and framing the immigration and settlement experience of the Filipino community in Canada, and particularly in Toronto ${ }^{1}$.

Filipinos are a relatively new ethnic group to Canada. The first wave of significant Filipino migration to Canada, particularly to Toronto, is documented to have started in the 1960s (Kelly \& Lusis, 2006). Unlike the current situation with the LCP, most of these early immigrants arrived in Canada with landed status, were accompanied by family members, and migrated as professionals who found employment in job sectors where Canadians were also employed, particularly in the health care sector as nurses and also clerical work.

Filipino migration into Canada has been relatively steady since the 1960s, with the Philippines consistently ranking as one of the top source countries (Bonifacio, 2013).

\footnotetext{
${ }^{1}$ The importance of this history to this study is further explained in the Conceptual Framework section of this paper and provides justification for employing the critical language and perspective from postcolonial studies at points throughout the analysis of the data.
} 
Despite this fact, Filipinos remain an "invisible visible minority group"2 in Canada (Ty, 2012) largely due to a tendency of policy makers and others to group them in with other Asian ethnic groups - such as the Chinese, Japanese, and Korean - rather than treating them as a distinct group. Nonetheless, information is available that shows Filipino migration to Canada has increased rather substantially since the 1990s. This second wave of Filipino migration to Canada brought more professional migrants, but this period saw a significant rise in the numbers of those arriving as temporary foreign workers. Indeed, labour migration has recently become one of the main avenues for economic growth in the Philippines and is actively promoted by the government, which has taken to calling its Overseas Foreign Workers Bagong Bayani or 'New Heroes' (Lindio-McGovern, 2012; Ogaya, 2006; Parreñas, 2006). This mythologizing of labour migration is internalized by many Filipinos who equate stability and life securities for their families with migrating in search of work - in other words, to move upwards by moving outwards (Parreñas, 2006). In Canada, these foreign workers were and are mostly domestic caregivers coming through the Live-in Caregiver Program.

\subsection{The Live-In Caregiver Program (LCP)}

The Live-in Caregiver Program (LCP) is a migration stream in Canada that employs qualified individuals as temporary work migrants who are given an opportunity to apply for permanent residency after completing a mandated period of work under specified conditions. The LCP was put in place by the Canadian government to replace the Foreign

\footnotetext{
2 This 'invisibility' refers to lack of recognition or presence in multicultural Canadian society, while 'visible minority' refers to the identifying feature of this group as a racially visible one. The theme of invisibility is a significant one in many works on Filipino identity in Canada. See R. S. Coloma, B. McElhinny, E. Tungohan, J. P. Catungal, L. M. Davidson (2012) for further reading on this topic
} 
Domestic Movement (FDM), which existed from 1980-1992 (Kelly, 2006; Schecter, 1998;

Spitzer \& Torres, 2008). Both programs, gender-oriented towards women, involve the issuance of temporary work visas which require the caregiver to live and work in the home of a specific employer. After two years of employment under this program, its participants are allowed to apply for permanent residency status, and the majority $\mathrm{do}^{3}$. Criticism of these programs generally includes "workplace abuses, curtailed citizenship rights, the stigmatization and racialization of Filipina femininity, institutionalized deskilling, and the psychological traumas of family separation" (Kelly, 2006).

According to Citizenship and Immigration Canada, official work responsibilities of caregivers involve performing private in-home services for Canadian families without supervision, particularly the care of children, people with disabilities, and the elderly. Livein caregivers are required to complete 24 months of documented, full-time, live-in domestic work within a four years of residing in Canada in order to be eligible to apply for permanent residency status to Canada (CIC, 2014). The LCP is one piece of the evidence that indicate current Canadian immigration policy is undergoing a shift towards emphasizing temporary labour migration programs in which settlement migration becomes more overtly market-driven and there are two-step in the process of eligibility towards permanent residency and citizenship (Pagaduan, 2006).

Key aspects of the LCP are the living-in requirement, employer specific work permits, and the temporary status of the worker, with the possibility of being eligible for

\footnotetext{
${ }^{3}$ However, there is no guarantee that permanent residency will be granted after the completion of the program. In fact, even though the number of women accepted into the program remained steady/increased in 2011 and 2012, the total number of live-in caregivers to have successfully become permanent residents decreased from 5,033 in 2011 to 3,690 in 2012 (CIC, 2013).
} 
permanent residency and future citizenship. Since its inception, the LCP has primarily comprised Filipina workers. The dominance of Filipinas in the program is aided by stereotypes of Filipinas as being particularly obedient, hardworking, and nurturing (Parreñas, 2001; Tung, 2000) which have made them target workers for the LCP and have also led to their recruitment in high numbers into western countries as mail-order brides (Philippine Women Centre of B.C., 2000). The recruitment of Filipinas "answers both the economic crisis in the Philippines and a labor market and child-care crisis in Canada" (Pratt, 2012, p. 39). These are important concerns, as discussed in the Literature Review, when considering the terms on which the live-in caregivers are deemed welcome by the nation state and how their status is negotiated within the larger Canadian society.

\subsection{Conceptual Framework ${ }^{4}$}

This study is largely informed by academic literature on media studies and the social constructions of race and gender in the scheme of the global migration of labour. Racist discourses once served to justify European slavery and colonial conquests as moral and natural, and such discourses continue to replicate themselves in contemporary Western societies and practices in complex and usually more covert ways.

Drawing upon the work of Foucault and Said, Hall (2007) discusses modes of representation and identification that construct meaning and produce certain power relations between groups. The effect of such an assumption is a naturalized understanding of "the West" in binary opposition to "the Rest" in which 'representation' becomes reality:

\footnotetext{
${ }^{4}$ Arguments made in this section have been adapted from an unpublished term paper by the author titled "Politicizing Pigmentation and Privilege: Idealizations of Whiteness and Feminine Beauty in Postcolonial Contexts."
} 
"It produces knowledge that shapes perceptions and practice. It is part of the way in which power operates. Therefore, it has consequences for both those who employ it and those who are 'subjected' to it" (Hall, 2007, p. 60). Embedded knowledge systems, values, and assumptions circulating in contemporary Western societies fail to question the validity of racial ideologies. Thus it is important to bring such a critical awareness to bear on a subject of the media representation of the figure of the racialized female migrant worker from a socalled "Third World" country who is at the centre of Canada's Live-In Caregiver Program. 


\section{LITERATURE REVIEW 5}

The main focus of this literature review is to provide an overview of the main themes and points of discussion in existing academic literature on Canada's Live-In Caregiver Program (LCP) and its workers. The academic literature most relevant to this major research paper are those texts that address the political, social, economic, and personal (from the perspective of the workers) ramifications of temporary foreign workers program in general, and Canada's recruiting of gendered domestic labour from the Philippines for the Live-In Caregiver Program more specifically. The academic literature reviewed employ both qualitative and quantitative methodologies in order to raise questions about the consequences for treating migrant domestic workers as, on the one hand, commoditized labour and, on the other hand, as complex human beings whose rights should be acknowledged and protected. Also of interest to this paper is investigative research that employs critical discourse analysis to expose the role newsprint media play in constructing and disseminating certain discourses about temporary migrant workers.

\subsection{The Globalization of Domestic Labour}

One of the main themes that emerge in academic writing on Canada's Live-In Caregiver Program (and also on gendered international labour migration in general) is the globalization of domestic labour. Attention is paid to the gendering (that is, feminizing) and racializing of this form of labour as workers in the program are 'women of colour' from impoverished countries. The LCP is noted for actively constructing and reproducing a particular kind of migrant worker for domestic labour through intersections of class with

\footnotetext{
${ }^{5}$ This chapter has been adapted and edited from an unpublished term paper by the author titled "Literature Review of the Live-In Caregiver Program and Narratives of its Workers".
} 
race and gender (Barber, 2008; Lee \& Johnstone, 2013; Parreñas, 2001). In fact, there are arguments condemning the existence of programs such as the LCP because the 'marginalization of women is ingrained in the very legislation' (Lee \& Johnstone, 2013, p. 401). The LCP in particular is ethnically cast, as it is comprised in large part Filipina women, most of whom are young mothers with children of their own that they have to leave behind. In the literature, family separation is a prevailing theme and concern as these women have to forego physical proximity (which can often lead to emotional distance, especially in the case of children left behind) from their loved ones in order to find jobs elsewhere as independent working migrants.

As migrant workers, Filipinas take on the responsibility of earning for their families, thereby upending stereotypical notions of gender roles and identities - including those of the docile, domesticated Asian woman. Indeed, a number of scholars have noted that Filipina domestic labour constitutes one of the largest flows of contemporary global female migration (Parreñas, 2001; Spitzer \& Torres, 2008). Yet, ironically, the terms used to describe the work these women do - domestic servants, nannies, nurturers, caregivers perpetuate stereotypes about "women's work" and factor into the structural inequities of, and the workers' experience of disadvantage in, the program (Lee \& Johnstone, 2013). Thus the globalization of domestic labour has created a new and complex form of family structure best summarized as "the transnational family: a postindustrial household structure with preindustrial values" (Parreñas, 2001, p. 80). 
Tellingly, in the data analyzed for this study, "live-in caregiver," the official job title used in the LCP, is often conflated and used synonymously with "Filipina nanny." ${ }^{6}$ Perhaps because the majority of LCP workers come from the Philippines, the academic literature tends to discuss the LCP as if it were exclusively a Philippines-to-Canada labour migration movement. The Filipina woman has thus become the symbol of domestic labour in Canada, and her place in society is the invisible space of the domestic sphere (Lee \& Johnstone, 2013; Parreñas, 2001). Integral to this positioning are perceptions of Filipina women as naturally domesticated and subservient housekeepers who are meant to be caregivers (Spitzer \& Torres, 2008). Such perceptions are problematic because they not only essentialize Filipinas but also trivialize and devalue the work women in the LCP workers do by characterizing it as a natural function of who they are instead of recognizing it as a job like any other (Tung, 2000). Ironically, these Filipina migrant workers tend to come from varying professional backgrounds not related to caregiving (Brickner and Straehle, 2010). But as a consequence of the racial and culturally-bound traits stereotypically ascribed to Filipina women, domestic labour is deemed natural to them; it is the kind of work that is thought to require no particular or discernable skill set and so priority is not given to adequate compensation - monetarily and otherwise - or protection in the workplace. As Brickner and Straehle (2010) point out, since the work of these racialized women is regarded as unskilled and natural to them, the tendency is to disavow the meaningful contributions they make to the social and economic welfare of the society at large.

Furthermore, live-in caregiving is not only highly emotionally taxing (and therefore regarded as feminine) work, but it also leaves the worker vulnerable to exploitation and

\footnotetext{
${ }^{6}$ Implications of this detail are further discussed in Section 4.1.
} 
abuse given that the work is confined to the private, unregulated space of the home. Workplace conditions such as the long-term placing of the worker within a household that is not her own, her position of dependence which often necessitates showing deference to the employer regardless of the circumstance, and her severance from family, homeland, and professional ties make her more vulnerable to exploitation and abuse (Parreñas, 2001).

The risk of exploitation is also a consequence of Canadian ethnocentrism. For example, despite the fact that most Canadians would find at least some of the terms of the LCP (such as the separation of workers from their families for long periods) unacceptable for themselves, they have no problem seeing the program in a favourable light as providing opportunities for Filipinas (Pratt, 2009). As Lee \& Johnstone (2013) point out, “The Filipino mother is regarded by Canada as first and foremost a worker who can be separated from her family ... but a Canadian woman would be censured for abandoning her children or her partner. This double standard is jarring" (p. 410). Furthermore, uncritical acceptance of the idea of Canada as an economic 'promised land,' as a land of opportunity for foreigners and that access to such opportunities is the primary motivator for migrants reinforces the global north-south power divide between Canada and the Philippines.

The subordinate positions of the Philippines and Filipina women in general is maintained in "the global political economy" (Lindio-McGovern, 2012, p. 40) through transmigratory domestic labour. In addition to the domestic caregivers themselves, several actors interplay in this "labor export web," each with their own interests and investments: the labor-sending state, the labor-receiving country, private traders or recruitment agencies, and employers (Lindio-McGovern, 2012). In this sense, the domestic workers, 
most often female, are commoditized (Lindio-McGovern , 2012; Parreñas, 2001; Urbano, 2012) and become largely invisible as human workers as they are exchanged between actors at low prestige and for low pay.

Additionally, both cultural relativism and an uncritical view of these global politics can obfuscate the complexity of the migration experience and motives of these domestic workers. Lee \& Johnstone (2013) continue:

Conflicting discourses have developed in the source countries. The Filipino caregiver is praised as sacrificing her own interests and going abroad for the benefit of her family and country but at the same time there is also a developing literature censuring her as a "bad mother or wife" abusing and neglecting her children. (p. 410)

\subsection{Blurring Private and Public Spheres of Work and Home}

Another main theme in the academic literature on the LCP is the way in which the program effectively blurs boundaries between the private sphere of the home and family and the public sphere of labour and the economy. As discussed above, this can be explained by the nature of domestic labour as well as by the replication of gender inequalities (rooted in "traditional" notions of "women's work') that place women and their work in the private domestic sphere (Tung, 2000). Intersecting with their gender, the workers' racial and class (that is, their decreased social status in Canada) identities are also contributing factors. The contradictions inherent in the experience of Filipina LCP workers who, on the one hand, are active contributors to both domestic and global economies and, on the other hand, are engaged in undervalued, feminized work within the home unsettle comfortable and 
singular notions of gender. As Lan (2003) argues, "they reconstitute the meanings of womanhood when occupying multiple positions or shifting between them, and they bargain with the interchange between monetary value and emotional value associated with their multiform labour" (p. 205).

The liminal space they occupy and are forced to negotiate is also evident in the fact that "the domestic worker is admitted into Canada but barred from political membership, employed in a workplace but often excluded from worker-protection laws, resident in a household but a part of the family" (Macklin, 1994, p. 13-14). This experience of being allowed in but not fully accepted is reflected in accounts of the domestic worker as being "not one of the family" or mythically "like one of the family" (Parreñas, 2001, p. 180; emphasis added). The following anecdote is illustrative: "When she arrived in Canada, Sabrina was told by her employer that she 'had to' be part of the family. She soon discovered that this would mean a lack of privacy and personal time for herself!" (Arat-Koç, 2001, p. 44). Thus the boundaries between work and home, and public and private life, must be negotiated.

In discussions of the public-private dichotomy, the academic literature also addresses the conditions that enable exploitations and abuse in the domestic work environment. As indicated earlier, the opportunities for exploitation and abuse are greatly increased since the work environment, traditionally located in the public domain, is in this instance within the private domestic space of the employer's home - a space that is not readily open to external regulation. The blurring of boundaries between public and private also applies to the lives of workers who have to resort to long-distance mothering (Pratt, 
2009) while tending to children and homes not their own. They are monetarily compensated for the kind of labour they would otherwise be doing in their own home, but the emotional investment required of such work is made to others, not their own families. Since domestic labour includes work of an emotional and social nature, it thus produces an intermingling of the economy of labour with human affect. It is debatable whether this type of affect is debilitating or rewarding for LCP workers (Parreñas, 2001) who, as Lan (2003) notes, are "housewives in home countries who become breadwinners by doing domestic work overseas" (p. 189) for an employer and families that are not their own. Lan (2003) further describes "the simultaneous occupancy of domestic and labour force roles. Migrant women sell their domestic labour in the market but remain burdened with the gendered responsibilities in their own families ... they experience a relation of conflict or disarticulation between these two simultaneous roles" (p. 189).

While the economic compensation LCP workers receive in exchange for their labour can be readily identified and assessed, the emotional and social cost of their work cannot be so easily accounted for or measured. In attempts at balancing their lives and negotiating the boundaries between work and their own family life, LCP workers very often engage in transnational acts, such as transnational mothering, sending home remittances and gifts to financially support family members, and doing an array of other things to enforce ties impaired by physical separation (Lan, 2003).

The conflicting roles LCP workers are forced to play result in their having to negotiate new identities for themselves and grapple with issues of self-worth, and they also have to re/assess the value - in emotional, economic, and professional terms -of their 
labour. It has been argued that these concerns and issues, although important, are made invisible within the conditions and structures of the LCP itself (Arat-Koç; 2001; LindioMcGovern, 2012). Additionally, the complexity of worker experience they reveal tends to be oversimplified in some articles in which the work and worth of LCP workers are understood only within the parameters of paid caregiving and their temporary status (Tung, 2000).

\subsection{Transitions from Temporary Foreign Worker to Permanent Resident}

The LCP is a unique temporary work program as its workers are expected to perform labour with precarious temporary status for the duration of at least two years before they are given the opportunity to apply for permanent residency status, and eventually obtain full citizenship status in Canada. Canadian citizenship is typically viewed as the primary motivator for workers to apply to the LCP. With its stipulations, the LCP creates a pathway to permanent residency for a specific type of economic migrant worker identifiable within public discourses according to particular constructions of gender, race, and perhaps class. But although a pathway exists, the academic literature indicates that the process is mired in problems. There are, for example, as Pratt (2009) points out, concerns that "the program creates deeply exploitative working and living conditions, and leads to the long-term deskilling of the mostly college-educated women who eventually migrate to Canada (and sponsor their families) after completing the LCP” (p. 6).

Further study of specific barriers to workers' settlement and integration and to their improved career prospects and economic stability (Spitzer \& Torres, 2008, p. 30) have been called for to aid in measuring outcomes and to help guide and shape policy changes 
and future implementations of the LCP. Spitzer \& Torres (2008) further point to socially inclusive policy recommendations under three general categories for the LCP:

1) Address barriers to settlement and integration unique to the status of live-in caregivers;

2) enhance opportunities for live-in caregivers to pursue careers; and

3) eliminate the exploitation of live-in caregivers.

The older academic literature is more concerned with the labour relationship between the country of origin (the Philippines) and the destination country (Canada). But in more recent scholarship, there has been a shift in emphasis towards understanding the transnational and settlement experiences of the LCP workers through giving attention to the women's personal stories and accounts of their own lives.

\subsection{Family Separation and Reunification}

Arat-Koç (2001) notes that "the LCP program, by definition and by design, is built on the premise that the foreign caregivers who arrive in Canada are - or should live as - single people" (p. 21). In other words, live-in caregivers, unable to arrive with their families and loved ones, are assumed to be single and must live in Canada as such. Prolonged family separation is the inevitable outcome for all of these live-in caregivers. The severity and trauma of this experience may be underplayed or legitimized by some through cultural relativism: "mothering long distance may seem 'natural' for Filipinas, especially given popular imaginary in Canada of large extended Filipino families that can effortlessly care for children in a mother's absence" (Pratt, 2012, p. 78). Additionally, due to the low income and precarious status of these, family sponsorship in the long term is a difficult and timeconsuming process for live-in caregivers (Arat-Koç, 2001). 
If and when family sponsorship is successful and reunification in Canada does occur, the resulting family relations are often profoundly strenuous. Pagaduan (2006) explains:

Domestic work, once viewed as contributions of wives and women to household harmony and long-lasting marriage, now threatens many families with disunity and insecurity. Marital separations, child delinquencies, and dysfunctional families, the psycho-social stresses on the families left behind as well as the migrant worker herself, are still the unvalued and neglected costs of overseas work. (p. 80)

Examples of 'child delinquencies' resulting from the experience of separation and marginalization of Filipino youth include high dropout rates and underperformance in schools (Kelly, 2006) as well as youth violence and gang involvement (Catungal, 2012). This problem often results in feelings of guilt and failure in the work that live-in caregivers had struggled to achieve: "Immigrant success stories are typically tied to children because migration is often done in their name, for their future. In this sense, children often bear responsibility for redeeming or making good on, and in the face of, their own and their family's trauma" (Pratt, 2012, p. 71). Relationships with family members, especially their children, become strained and alienating (Bonifacio, 2013; Cohen, 2000; Pratt, 2009). Thus the relationships to their children are negated under the legislation of the LCP that prohibits the immediate sponsorship of the live-in caregiver's immediate family members. The underlying message is that the caregivers' worker status is incompatible with their other vital roles as human beings, resulting in a potentially psychologically damaging experience (Arat-Koç, 2001). 


\subsection{Theme: Narrative Discourses (Personal and Public)}

Methodologies for studies conducted on the LCP in which observations are made based on interviews conducted with current and former LCP workers are often qualitative in nature. Interviews with and oral testimonials from members of Filipino communities tell stories of maternal grief, absence, and longing (Pratt, 2009). Quantitative data - mostly comprising of statistics - is also used though generally only secondary to the qualitative methodologies in this type of research. Qualitative data can be more personal and relay affective information about the experiences of live-in caregivers. The objective of such studies is to "evoke an affective response from policy makers and Canadians who may be unaware [of the conditions and hardships endured by those foreign migrants coming into Canada through the LCP]" (Pratt, 2009, p. 6), to produce and speed up the processes of change, and to mitigate instances of abuse and grievous work conditions.

Such methodologies, as Davidson (2012) points out, ensures that the live-in caregivers' "discursive practices ... are part of a sense-making process to understand the conditions they experienced under the LCP, while maintaining Canada as a site in which hope of a better life remains attainable and realizable" (p. 157). Lan (2003) further states: "domestic labor, both paid and unpaid, is entangled with an interchange between emotional value and monetary value" (p. 189) and therefore their affective narratives and longing for hope (Davidson, 2012; Pratt, 2009) attempt to reconcile the two. Much of the current academic literature comprises studies of how personal lives and experiences are configured as public and shared narratives and how a 'circulation of affect' can create borders and communities of insiders and outsiders (Pratt, 2009). 
Critical discourse analysis is also undertaken as a methodology for assessing public narratives; such discourses are examined to determine how language is used to justify exploitation of vulnerable temporary foreign workers. The impact of mainstream media representations and discursive practices on perceptions of the LCP and its workers has not yet been covered in detail in the academic literature on the LCP. Various scholars from a variety of disciplinary perspectives have given attention to ways in which media discourses and images produce, reproduce, as well as challenge notions and assumptions regarding gender, race, class, and other markers of social identity construction which contribute to social inequality and imbalances of power $^{7}$ (Hall, 2007; Hart, 2013; van Dijk, 2008). Mainstream media discourses about foreign workers bring the subject to the attention and awareness of the general public. This can lead to public consent for the continuation of this program and the precarious labour market regime it is part of; or they can motivate public condemnation and protest, leading to social justice and political action. Such discourses can even intervene into the social identities of particular groups of people - such as immigrants, refugees, and foreign caregivers - all of whom may have been historically objectified in public media in essential ways , thus "denying them human agency and justifying exploitation" (Bauder, 2008). In an example of one of these studies (although not the LCP specifically), Bauder (2008) analyzes how popular news media narratives participate in creating stereotypes for temporary foreign workers: for example, the migrant as economic necessity, the migrant as social problem, and migrant's work opportunity as a kind of foreign aid.

\footnotetext{
${ }^{7} \mathrm{~A}$ more detailed discussion of this notion is present in Section 4.
} 
There may be a causal connection between such disempowering public narratives, the personal stories detailing their vulnerability and victimization that the live-in caregivers tell, and grassroots attempts at empowering and asserting the rights of workers. Support for establishing such connections can be found in interviews disseminated in the academic literature (Arat-Koç, 2001; Cohen, 2000; Ogaya, 2004; Parreñas, 2001; Pratt, 2009; Tung, 2000). It may then be possible to correlate and compare information gathered from both the personal interviews in the literature and critical discourse analysis of newsprint media, to see how media representations of, and discourses about, these workers function to ideologically legitimate the current practices of any temporary worker program (Bauder, 2008; Hart, 2013). The impact is because mass media, here particularly newsprint media, sees a much wider and more general audience than academic literature or specific reports from non-profit organizations. Its production value and wide dissemination lend to its role as a reflection of and reproducer of popular beliefs and assumptions (Hall, 2007; van Dijk, 1988).

This literature review provides a foundational base and some key word clues for the coding process of my research study. One difficulty that presented itself in the process of pulling together the literature review was finding studies that present more favourable arguments about the LCP and extol its benefits for the increasing number of migrants choosing to arrive in Canada through the program. Nonetheless, these academic sources discussed above proved very useful in creating a context for an analysis of the primary data source of this paper, the Toronto Star. It can be concluded that the findings of many of these studies in the literature review are communicated in order to achieve outcomes of social justice. One important consideration for any researcher who sets out to put the personal 
narratives of LCP workers on record is the extent to which his/her personal identity and social position vis-à-vis the interview subjects can impact the kind of information gathered and the interpretation of that information. Such a consideration is less urgent in the case of critical discourse analysis of existing print media where attention to language - how phrases and terms are used to connote or determine ideological meaning - is vital in providing insight into how individuals in the LCP are perceived and constructed in the social and popular imagination. 


\section{RESEARCH METHOD}

\subsection{Data Source and Sample: The Toronto Star}

The source of the primary samples used for this research study is the Toronto Star, which is the most widely disseminated newspaper in Canada. Increasing its availability, the Toronto Star can also be accessed through its online archives. Its main website, thestar.com, is also Canada's largest online news site. The primary sample comprises all Toronto Star articles and news stories on live-in caregivers from the Philippines from 1988, four years prior to the inception of the Live-In Caregiver Program in 1992, to the end of May 2014 (see Appendix). The start date, which falls during the period Canada's Foreign Domestic Movement (FDM) was still in operation, coincides with the first mention of Filipina caregivers in the Toronto Star. The FDM, which began in 1981, would later become the Live-in Caregiver Program in $1992^{8}$. Already participants in the FDM, Filipinas began to constitute the vast majority of workers in the Live-In Caregiver Program, and ensuing discourse on gendered and racialized labour migration began to cohere around their presence.

The study encompasses the entire sample of articles found (totaling 132) related to Filipina live-in caregivers in the Toronto Star ${ }^{9}$. Using the entire range of news items relevant to the topic allows for (1) broad and quantitative, and (2) specific and qualitative presentation of the data for analysis. It is possible, for example, to indicate the frequency

\footnotetext{
${ }^{8} \mathrm{~A}$ pattern of high rates of overall temporary work migration outflow from the Philippines began in the midlate 1980s (Barber, 2008).

${ }^{9}$ There were 74 other articles flagged in the search but excluded in the data sample as they did not contain relevant content material. Despite the large volume of articles collected, there is no definitive way to determine that these were the only news articles on Filipina nannies in the LCP in the Toronto Star during this time period.
} 
with which news items in a particular category of analysis occurred and the reason why, and to also achieve deeper analysis of the data by giving closer attention (including quoting directly from) individual news items. Furthermore, the timeframe allows any discursive or narrative shifts in the representation of and response to Filipina caregivers throughout the years to be monitored, noted, and analyzed for this research project. The unit of data that is coded is, in each case, the entirety of the individual story text. Due to time restraints, other presentation features of the unit of analysis such as headlines and layout positioning within the newspaper were set aside and not included in the data collection or analysis.

\subsection{Data Collection Process}

Since the Toronto Star has online databases available - extensive and searchable from 1985 to the present day - data collection was broad and systematic. ProQuest and a digital subscription to the Toronto Star website, thestar.com, were used to access the data. At the start of the data collection, the following key word search functions were used to extract news items and articles relevant to the research topic: "domestic worker," "live-in caregiver," "LCP," "Filipino/Filipina." As this process continued, other frequently occurring key words present in the data gathered were also later incorporated into the search to ensure as comprehensive a data set as possible. These additional key words included "Filipino/a nanny" and "Filipino/a caregiver." Articles and news items dealing with domestic work in general, the homecare crisis in Canada that justified the initiation of the LCP, and Canadian-based caregivers working outside of the LCP or abroad were excluded from the sample. Other items flagged in the search but not included in the data samples were stories about the Filipino community (although not explicitly tied to the LCP) - youth 
violence, cultural and arts events, etc. - and numerous classified ads from employers and recruitment agencies.

There are little to no ethical issues associated with this research paper given that the data samples have been acquired from already publically available documents. Despite the considerable benefits to this research derived from the relative ease of public acquisition and lack of ethical issues, it is nevertheless a time-consuming and laborious undertaking which requires great attention to detail and organization in order to keep each database ordered and the data analysis process systematic, consistent, and methodical. Coding the articles is a subjective process, but frequent re-visits in the data organization phase has hopefully produced the most fair and accurate results possible.

\subsection{Thematic/Categorical Coding}

Data organization took place in various stages prior to and in conjunction with data collection. This included note-taking, the creation of web diagrams, analytic memo-making, and eventually coding the information into a table that underwent a few revisions (see Appendix for final version used). The coding undertaken in the research is the "mechanical data reduction and analytic categorization of data into themes" (Neuman, 2004, p. 321).

There are several ways to describe the different types of coding for this research study: quantitative, or the frequency counts of items in each category; and qualitative, the "fracture" and rearrangement of data into categories that facilitate comparison between categories (Maxwell, 2005). The file format of the data sources and the master coding table are digital files. Categories for coding were narratively- and thematically-based and include live-in caregivers as activists, as mothers, as victims, as labourers, and as foreigners. 
Initially, coding also sought to identify narrative tone in the data sources to determine whether the depiction of these caregivers was positive, negative, neutral, or a combination thereof. However, coding in this manner proved difficult and potentially misleading as most if not all articles portrayed multiple actors in various lights; therefore, implicit preconceptions within the data are most readily discernible when the information is analyzed more broadly and qualitatively. Thus coding the news stories involved several phases from observing general to more specific attributes, such as looking at how diction and syntax are used, how rhetorical devices are used to relay particular perspectives and explain events, and how thematic structures are systemized in general.

Throughout each phase, notes were made extensively with potential new categories and subcategories, ideas, anomalies, or follow up questions emerging. These organizing strategies and systematic processes served to operationalize the coding of the themes present in the content. Particularly prominent or frequently recurring variables and themes became more highly prioritized as the research data was finalized for analysis.

\subsection{Data Analysis: Critical Discourse Analysis (CDA)}

Because the primary data source is newspaper content, this paper employs critical discourse analysis (CDA) as its primary and most suitable means of investigation. Such analysis is centered on the tenet of "language as social practice" (Fairclough \& Wodak, 1997). As defined by van Dijk (2008), "CDA is a type of discourse analytical research that

primarily studies the way social power abuse, dominance, and inequality are enacted, reproduced, and resisted by text and talk in the social and political context" (p. 85). 
Newspaper text, in this regard, comprises the discursive content or language that is illustrative of the social systems that are in place.

CDA is a means by which research/ers can respond appropriately to real world concerns and forge useful links between academia and society. CDA can achieve these ends by enabling social awareness to "expose and ultimately resist social inequality" (van Dijk, 2008, p. 85). As such, CDA encompasses a large and diverse scope of theoretical frameworks and types of analysis. The unifying characteristic of CDA is that its frameworks and analyses interrogate social problems through a multidisciplinary lens in order to explain how discursive structures confirm, challenge, or problematize relations of power in society (Fairclough \& Wodak, 1997; van Dijk, 2008). It is understood that socially constructed identities lend certain groups privilege and power over others. These social identities are constructed within various discursive texts that circulate within societies, and are constantly being recreated, reinforced, and negotiated. Discursive texts include those produced by mass media (such as newspapers), which is a significant force in contemporary societies particularly because of the possibility of reaching large audiences. Mass consumption of such discursive texts often results in unquestioning acceptance of various ideologies - including those about racial and gender identities - which reproduce and reinforce social inequalities (van Dijk, 1988). The result is that public and private experiences of the world are unconsciously influenced and framed by prevailing preconceptions and biases that are largely taken for granted. Though they may appear "natural," these ideologies exist and are constructed by consensus, or amongst members of the dominant group (van Dijk, 1988). 
In short, critical discourse analysis deals with the relationship between discourse and power, text, and society (van Dijk, 2008). This study will show how news media discourse in the Toronto Star attempts to unpack some of the underlying ideologies of political discourse surrounding the LCP and its workers while recreating, reinforcing, or negotiating its own ideologies about the same topic in implicit ways. In the employment of critical discourse analysis, attention to language - how phrases and terms are used to connote or determine ideological meaning - is significant in providing insight into how individuals in the LCP are perceived and constructed in the social imagination.

As is seen later in this study, media and cultural studies scholarship on the social construction of race complements a critical discourse analysis approach. This combination of analytical approaches allows for the examination of rhetorical, linguistic, and sociological devices that may be employed and exploited in media discourse on immigration and anti-immigration (Hart, 2013). Therefore, public texts, such as newspapers, are crucially linked to the social learning of power dynamics related to gender inequality and racism (van Dijk, 1988).

\subsection{Study Limitations}

As useful as it may be, CDA also has some limitations. These are outlined by van Dijk $(1988 ; 2008)$ who points out that because CDA is highly theoretical and ideologically driven, there is always the possibility of a gap between intellectual work and social action. Additionally, it would not be possible to detail all of the syntactic, stylistic, or semantic structures at work in a representative sample or an entire unit of text. It is important therefore for the researcher to not only be systematic in analyzing the data but to always remain focused on the specific objectives of the study. The incorporation of other critical 
approaches (such as Hall's media and cultural studies work) may also be necessary to more fully explain social structures, as sociological and political investigation is as important as linguistic analysis.

In addition to the methodological constraints identified above, the study itself has its own limitations. As the articles were drawn from online databases, the scope of this study does not incorporate any presentation features, such as the design structure and the visual properties of physical newsprint media, of the news stories and articles. Visual analysis - including the use of the photos, location, and size of the article - would have been significant features to analyze to determine the discursive impact of images and other nontextual signifiers, particularly in regard to projecting and cementing certain ideas and stereotypes about social groups in the popular imagination. However, time and space constraints prevented the extension of the analysis into these areas. 


\section{RESEARCH ANALYSIS}

\subsection{Findings: Major Narrative Themes and Categories}

Findings show that there are a number of identifiable ways in which Filipina live-in caregivers are depicted and essentialized in articles in the Toronto Star. These live-in caregivers are discursively positioned in ways that have ideological implications in terms of (1) the public perception of live-in caregivers, and (2) a perception of live-in caregivers in relation to Canadian society and its values. The categories for coding the newspaper articles had been pre-determined based on major themes that emerged from the academic literature review. Table 1 depicts the number of times a narrative code or category appears in the data set. Depending on their content, some articles were coded under more than one category.

Table 1: Articles Coded in the Toronto Star on Live-In Caregivers from 1988-2014

\begin{tabular}{|c|c|}
\hline Category & \# of Times of Occurrence \\
\hline Filipina caregivers as Foreigners & 97 \\
\hline Filipina caregivers as Victims & 75 \\
\hline Filipina caregivers as Workers & 48 \\
\hline Filipina caregivers as Mothers & 41 \\
\hline Filipina caregivers as Activists & 31 \\
\hline
\end{tabular}

Further coding of articles as positive or negative would have oversimplified the complexity of the narratives that emerged and obscured any ambivalence in the language used in the articles. Presenting such data numerically would also not have been useful. Instead, and 
more significantly, discursive subcategories that emerged during coding of the data are identified and discussed in the analysis,

Analysis of the data focuses on interpreting the news content in their context and through the lens of critical literature on the global migration of gendered domestic labour, postcolonialism, and media studies. In particular, the analysis uses existing academic literature on live-in caregivers and media representations of racialized migrant labourers as a guide to answering the questions posed in this research paper. Running throughout the analysis is an engagement with structures of power and subordination, and with visibility and invisibility, as they relate to the experience of live-in caregivers.

An important observation is that live-in caregivers are most commonly referred to as "Filipina/o nannies" in the news articles; the interchangeable use of these terms indicates that (at least for the Toronto Star and presumably its readership) it is assumed that (1) all live-in caregivers are of Filipina origin ${ }^{10}$, and (2) that these caregivers are nannies by profession ${ }^{11}$. Perhaps this is no surprise as it has been documented that anywhere from $70-90 \%$ of caregivers in the LCP are Filipina in ethnicity (Hall, 1992; Kelly, 2006; Kelly et al., 2011; Spitzer \& Torres, 2008). The confusion is not corrected in any of the Toronto Star articles or in the comments section of these articles, indicating wide acceptance of these assumptions.

\footnotetext{
${ }^{10}$ While the Philippines is the primary source country for live-in caregivers in Canada, workers in the program also come from India, Slovak Republic, England, and Jamaica (Kelly, Park, de Leon, \& Priest, 2011).

${ }^{11}$ Kelly et al. (2011) notes that $63 \%$ of LCP principal applicants in 2009 had at least a bachelor's degree. Note, however, that this proportion is not specific to LCP applicants only from the Philippines.
} 


\subsection{Filipina Live-in Caregivers as Foreigners}

In the Toronto Star, live-in caregivers are found to be represented most frequently in terms of their status as 'foreigners' in Canada. This is exemplified in the rather ubiquitous characterization of live-in caregivers as "Filipina/Filipino" in instances where it is not a necessary descriptor to add. This can be seen in the following examples:

(1) "She was touched by Tejada's story because of the wonderful care her late mother, Georgina Casey, got from the family's Filipino live-in caregiver" (Keung, 2008a; emphasis added).

(2) "Earlier this year, Joelina Maluto, a Filipina mother of four..." (Brazao, 2009c; emphasis added).

The effect is a systematic association between live-in caregivers and Filipinas, and of caregivers as non-Canadians or foreigners. Thus caregivers are identified according to their ethnic (and national and cultural) difference from Canadians, which makes it possible to assign essentialized characteristics to them.

\subsubsection{Notions of Class.}

The use of the identifier 'Filipino/a' sets up the caregivers as different from and in opposition to Canadian (i.e. white) women, and establishes an "us" and a "them" in the readers' mind. As Van Dijk (1988) notes, "white journalists primarily write as white ingroup members and, hence, represent ethnic minority groups in terms of them and not as part of us" (p. 156). While not all of the Toronto Star articles are authored by white Canadians, the writers do belong to an 'in-group' of Canadian citizens and remind the reader that the live-in caregivers are excluded from this group. 
This emphasis on ethnic, and national, difference also points to and reproduces ideas about the caregivers' class difference. It is significant that caregivers are identified as women from an impoverished country (the Philippines), who are consequently not only willing to do domestic work but will also do it under conditions that Canadian women would not accept. "These girls do things that no Canadian will do" (Keung, 2008a) runs one article, while a second trumpets that "Canada's gain is the Philippines' brain drain" (Cohn, 2009). The gap between Canadian women's ability to choose better jobs, wages, and employment conditions and the Filipinas' inability to make such choices underscores the latter's position within Canada as an economic and political underclass. Also, as Teelucksingh \& Galabuzi (2005) have pointed out, the practice of under-employing and streaming (in many cases professional) immigrants of colour into low-status, low-wage jobs has contributed to real class stratification in Canada, especially in high immigrantreceiving urban centres as Toronto. Given their precarious access to Canadian citizenship, Filipina caregivers are even further down the class ladder than underemployed immigrants of colour. In a similar vein, another article making the claim that a "labour scholarship empowers Canadian migrant workers" calls the scholarship "a symbolic way to get money back into the hands of workers from the global south" (Keung, 2011a). The underlying message is of giving the caregivers a handout as a hand up. The empowerment suggested is less about facilitating agency and more about allowing the lucky scholarship winner(s) from the global south to catch up and make the most of their Canadian experience.

It is thus evident in these examples that live-in caregivers and their class are framed not only in terms of difference, but also in terms of social hierarchy. This understanding is actually reinforced in the type of discourse constructed by the Philippine government 
regarding its workers overseas: "The fascination for economic upward mobility [...] is captured by the term Bagong Bayani that means 'New Hero'” (Lindio-McGovern, 2012; Ogaya, 2006, p. 119-120). Such constructions of a 'New Hero' reinforce an understanding that migrating to Canada for work results in a desirable elevation in class compared to those who remain in the Philippines (although the reality for LCP workers is that they are on a much lower rung of the socio-economic ladder than many Canadian citizens).

Yet, as Parreñas (2001) points out, female migrant domestic workers from the Philippines experience "contradictory class mobility" (p. 150) when they move out of their home country to search for work. Parreñas continues: "This contentious location refers to their simultaneous experience of upward and downward mobility in migration. More specifically, it refers to their decline in social status and increase in financial status" (p. 150). Filipina domestic workers abroad often must contend with the psychological and social ramifications of this shift in their status, and the loss of social and cultural capital that attends it. Yet, even though class identity is a complex process of negotiation for Filipina caregivers, news articles tend towards simplification by setting up class binaries in which these 'foreign workers from a poor country' in the global south are the disadvantaged in contrast to privileged Canadians.

\subsection{Filipina Live-In Caregivers in the LCP as Mothers}

Live-in caregivers are also commonly identified in the Toronto Star as mothers, both of their own children back home and as surrogate mothers providing care to the Canadian children of their employers. Maricon Gerente, for example, was a live-in caregiver dying from a brain tumour and only desired to see her children again: “Gerente's dying wish was 
to reunite in Canada with the two daughters - Lean, 14, and Saniel, 11 - she left behind in the Philippines" (Keung, 2013b). Similarly, Edna Aldovino had postponed her medical treatment for breast cancer in order to complete the work hours mandated in the LCP to bring her child, Kenneth, to Canada: it would be "the last gift she could give him" (Keung, 2014). This narrative theme seems to solicit sympathy and compassion for live-in caregivers, and remind readers of their shared humanity with the workers by foregrounding the importance of family ties and maternal love. It would appear that this narrative (somewhat) mitigates against the depiction of the caregivers as 'foreigners' and 'Other' by evoking a universal experience of motherhood.

Yet there is some ambivalence as even though readers are invited to see a commonality between themselves and the caregivers, there are reminders that the contexts and circumstances of the caregivers' mothering differ in important ways from Canadian (ideal) practices and values - such as the caregivers' transnational mothering vs mothering within intact nuclear Canadian families. Differences are subtly underscored at the same time it appears that positive parallels are being drawn. Indeed, the identification with motherhood elides the idealization - based on program stipulations that caregivers may not bring family members with them - that caregivers should arrive in Canada as single and unattached (See Section 2.4). Since mothering is an emotional and affective undertaking, identifying the caregivers with motherhood - without recognizing the emotional trauma inherent to separating women from their own children - so they can be surrogate mothers to other people's children, suggests that their capacity to mother and nurture is being recognized only in so far as to confirm their ability to care for Canadian 
children and to solicit public support for a government program that provides capable workers to look after the nation's young.

Since many of these women are already mothers or want to be mothers (for example, Juana Tejada, though childless, is linked to a family she misses back home and is quoted as wanting "to have kids and start a family" [Keung, 2008b]), they are already qualified for the job they were brought here for, so Canadian employers need not worry. In fact, the assumption that mothering and nurturing are inherent to the Filipina caregivers feeds into stereotypes about the docile, domesticated Asian woman; and it also serves to justify the undervaluing of their work as unskilled, which contributes to their subordinate status as workers and people.

\subsubsection{Transnational Mothering.}

A large part of live-in caregivers' narratives is that their main reason for coming to Canada in the LCP is to support their families back in the Philippines. This is reflected in observations that "dominant social discourse combines mother's work migration with the needs of the family" (Ogaya, 2006; Pratt, 2012) in the Toronto Star: "The sight of a Filipino nanny with young charges in tow is a ubiquitous one in GTA parks, libraries and drop-in centres. Many of these nannies are the key money-earners for their families back home in the Philippines" (Smith, 2012). Hence, due to economic hardship in the Philippines - which solidifies ideas about the migrant's second-class status in the minds of those in the receiving country - live-in caregivers are women duty-bound to meet the needs of their families by working abroad. Stating and highlighting this necessity sets up an opposition a difference - between Filipinas whose national and cultural circumstances require them to engage in the unnatural act of leaving their families to perform the natural act of mothering 
elsewhere, and Canadian women who are under no such constraints to contravene gender expectations. Domestic labour migration, and the transnational mothering it makes inevitable, is then perceived to be less an act of self-sacrifice on the women's part (which would bring these women closer to a Western feminine ideal of motherhood) and more symptomatic of the deficiencies of the non-western Other.

Hence, the sub-narrative of transnational mothering that emerges in the Toronto Star articles is an example of how live-in caregivers are represented through difference, simultaneously as foreigners and as mothers. In discussing the expeditions of colonial European travelers to the New World, Hall (2007) notes that "what disturbed western expectations, what had to be negotiated and explained, was their difference" (p. 212; emphasis added). Since the practice of transnational mothering complicates traditional Western notions of mothering, ${ }^{12}$ it is seen as natural to the Other. Not only that, but Western countries like Canada whose work programs create conditions that perpetuate the transnational mothering done by migrants from within their borders continue to reproduce such notions of difference - to their own economic and social advantage. As Arat-Koç (referencing the work of Hontagneu-Sotelo and Avila [2000]), points out, transnational mothering, or, the "maternal care work done across long gaps in time and distance that is widespread among migrant women doing domestic work globally [...] 'continues a long and dirty legacy of people of colour being admitted to some countries only through coercive systems of labour which do not recognize family rights'” (Arat-Koç, 2001,

\footnotetext{
12 This idea of the imposition of European categories and norms in representing the Other is a discursive strategy identified by Hall (2007). The four main discursive strategies (or formation processes in developing "the West and the Rest" discourse) are: '(1) idealization; (2) the projection of fantasies of desire and degradation; (3) the failure to recognize and respect difference; and (4) the tendency to impose European categories and norms, to see difference through modes of perception and representation in the West' (p. 215).
} 
p. 23). It is an example of the dual and intertwined processes of fantasy and degradation that Hall (2007) observed (see footnote above). In the case of the LCP, such processes are evident in Canadians taking advantage of the very thing (i.e. transnational mothering) that they deem in opposition to Canadian family values to prioritize the needs of Canadian children over those of subaltern children and keep the Canadian nuclear family intact, even if both parents work outside the home.

A few of the articles that appear in the Toronto Star do problematize the family separation inherent in transnational mothering. Since the children of live-in caregivers are far away in another country, they are rendered invisible compared to Canadian children. During separation and even after reunification, migrant mothers and their children often feel like "strangers" to each other (Cohen, 2000; Pratt, 2012). This concern is reflected in some of the news article titles: "Who looks after the nanny's children?" (Azam, 2001) and "[Filipino youths] are adjusting to new parents - their own" (Brown, 2013). This relatively recent topic inclusion in the Toronto Star recognizing the settlement experiences of Filipino children gives these children visibility. The longer-term settlement and family sponsorship experience of caregivers granted residency status may alter and add to existing discourse in the future.

\subsection{2 'Like Family to Us'}

As previously discussed, motherhood and dedication to one's children are important values in Canada, but only when it comes to Canada's children. The live-in caregiver comes to Canada unable to bring her own family and children but provides care to Canadian children and in Canadian families. The value placed on a nation's children is directly related to the political and social hierarchy that separates the wealthy north from the poorer south. 
For example, one editorial proposes "a Nanny's Day, a celebration of the domestic workers who provide families with security and comfort that their children, elderly parents or disabled relatives are being looked after while they themselves earn a living" (Tesher, 2000; emphasis added). The question is, which families are being valorized? Structures of power and privilege are at work here, as the underlying assumption is that it is 'our' Canadian families that the live-in caregivers care for that are worth celebrating.

Live-in caregivers occupy a unique position of being both included and excluded, of being regarded as both foreign and domestic, within their employers' home. As one critic argues, "though [the caregiver] is technically foreign, she is also enmeshed in the domestic, economic and legal machinery of Canada" (Macklin, 1994, p. 32). This sets the misbelief of being in the home but not one of the family, or, like one of the family: "Our nanny was like family to us" (Keung, 2008a; emphasis added), says one reader. A caregiver reflects, "Whenever I would hold any child, I would think I was holding my own. I looked after them as if they were my own because my own were so far away" (Taylor, 2009a; emphasis added). Some employers make extra effort to include their caregiver in the family, making sure that she "eats with the family and is included in special events" (Crawford, 2009).

However, as Macklin (1994) argues, "when employers insist that a domestic worker is 'like one of the family,' they unwittingly affirm the feudal quality of the relation. At no time was the domestic worker more like 'one of the family' than when her status was formally acknowledge to be that of a servant" (p. 32). Readers are reminded of this through a subtle discourse of difference and exclusion on live-in caregivers in the family of their employers, presented here in the binary form of "ours" and "theirs": 
(1) “Canadian families have relied on foreign domestic workers to care for our children and to keep our homes in order" (Waldman, 2009).

(2) "They work long hours caring for our children so that we can work productively" (Waldman, 2009).

(3) "They leave their families and give up careers in teaching, nursing and technology to come here and look after our children and frail elderly" (Monsebraaten, 2009).

Such “testimonials of mothers' grief may evoke empathy through an imaginative identification [on the part of Canadians] with [the caregivers'] loss"' (Pratt, 2012, p. 79). But even though a clear "Us/Them" division is not set up in the statements, there is a kind of 'self-incorporative identification' (Pratt, 2012) that nonetheless promotes subordination between the two groups. From narratives of this kind in the media, readers incorporate an aspect of the experience of live-in caregivers, just as the caregivers are incorporated into the home and family life of their employers - it is a partial inclusion, like an inclusion. The simultaneous insider/outsider positioning of caregivers and their complex transnational practices thus live-in caregivers fragment dominant notions of national identity, and their in-between status is aptly summarized in the statement that a migrant caregiver is "just a new Canadian with a foot in two different lands" (Oakland, 2000) and two different homes.

\subsection{Filipina Live-In Caregivers in the LCP as Workers}

Interestingly, narratives about live-in caregivers as primarily part of the labour force appear only a little more frequently (48 times) than those about their role as mothers (41 times). While it is common practice to represent temporary foreign labour migrants as a dehumanized and faceless labour power (Bauder, 2008; van Dijk, 1988), this does not 
appear - at least at first glance - to be the case with Filipina caregivers in the Toronto Star. There are news items in which efforts are made to recognize the work LCP caregivers perform as valuable to Canadian society; and, like the Bagong Bayani discourse in the Philippines, it seems as if live-in caregivers are represented as self-sacrificing heroes. Yet, a closer look at the way this narrative unfolds suggests that the discursive subtext might not be all that celebratory. The majority of articles tend to showcase a particular individual, as exemplified by the news coverage on Juana Tejada, "Canada's most celebrated caregiver" (Keung, 2011). The focus on Juana Tejada and the extensive coverage of her story over a period of time gives a human face to Canada's Filipina caregivers, adding a component of human interest to appeal to the public. Yet, by singling out one caregiver of many and highlighting the personal tragedy of her story (she was diagnosed with cancer while waiting on the results of her residency application, was denied health coverage and threatened with deportation), it can be argued that the Toronto Star sidelines the real concerns caregivers face as a group. By romanticizing and valorizing Tejada in the extremity of her situation, the news articles invited empathy with one individual, an empathy which would not necessarily be extended to others in her cohort. In fact, calls in the media for the Canadian government to ameliorate Tejada's situation by extending medical coverage and residency to her did not extend to public awareness of, or calls for, social justice responses to the structural inequities of the LCP (the observations made in Section 4.6 notwithstanding).

\subsubsection{Highly Educated / De-Skilled Workers}

In narratives of caregivers as workers, reference is also made to the high level of education and qualifications of the live-in caregivers and their de-skilling in Canada: 
“You hear stories (in the Philippines) about how nurses make $\$ 50$ an hour (in Canada), when it's the exact opposite. Nurses work as caregivers, professionals are working in factories"' (Taylor \& Keung, 2008).

This language serves to increase the social capital of live-in caregivers and represent them as potentially more valuable for the Canadian economy than their current line of work would suggest. While live-in caregivers are positively valued, and the issues of de-skilling and foreign credential recognition are legitimate ones, one of the underlying messages in this discourse is not necessarily benign. The assumption in this type of discourse is that live-in caregivers should be afforded more respect due to their higher education levels and professional skills than if they had none. Thus it continues to de-value domestic work in general and its significance in the Canadian economy.

\subsubsection{Caring, Hard Workers}

Live-in caregiver Juana Tejada is described as "tiny and soft-spoken" (Keung, 2009b) and as "a diminutive and soft-spoken Filipina caregiver" (Keung, 2009a). Similarly, former live-in caregiver and activist Pura Velasco is depicted as 'soft-spoken and 4 foot 11' (Brazao $\&$ Cribb, 2009b). These are a few examples of how media stories reproduce stereotypes of Filipinas as silent, nurturing maternal figures who are non-threatening in personality and physique. Some news stories adopt a more patronizing tone in attributing a difference in culture - or foreignness - to justify these stereotypes: "Filipinas are not usually vocal in complaining about their situations because it is in their culture to remain silent in spite of unreasonable and sometimes unacceptable conditions" (Baksh, 2008). Thus the stereotype of, or script, for the Filipina caregiver insists on "lumping all [their] distinctions together 
and suppressing differences" within the group (Hall, 2007, p. 212). Such stereotyping is a discursive strategy (and discursive discrimination ${ }^{13}$ ) in which the West fails to recognize differences within a racialized minority group. As a whole, live-in caregivers are described as "hardworking" women (Brazao, 2009c; Tesher, 2000) enduring many "hardships and sacrifices" (Monsebraaten, 2009). As a consequence, the naturalization of the stereotype of the caring, hardworking Filipina is, for example, institutionalized by the recruiting agencies who urge applicants to indicate a willingness to work twelve hours a day (Pratt, 2000).

Unfortunately, the kinds of domestic tasks that live-in caregivers are meant to perform are not concretely delineated in the program mandates. Cooking, cleaning, and providing education are all examples of what may constitute appropriate paid caregiving work to some while others take a less confident view. The privacy and invisibility of the household space lead to a further lack of transparency in regulating the boundaries of caregiving work. Thus the characterizations of Filipinas as hard workers coupled with the open-ended definitions of caregiving work can lead to circumstances that can then quickly spiral out of control into situations of abuse and exploitation. This becomes the basis of many arguments in the literature denouncing the LCP and its creation of victims out of its workers.

\subsection{Filipina Live-In Caregivers as Victims}

The victimization of live-in caregivers is the second most frequently occurring narrative category. News requires an explanatory framework and thus someone to attribute blame for a situation (van Dijk, 1988). There are three main identifiable

\footnotetext{
13 The idea of "discursive discrimination" is that it is subtle and coextensive with the general ideologies of a liberal society (van Dijk, 1988). The discrimination is not necessarily derogatory but is nonetheless not completely innocent either.
} 
antagonists in this narrative of live-in caregivers' victimhood: the Canadian government, abusive employers and agencies, and the ideology of the Canadian dream.

\subsubsection{Victims of the Government/Law}

The victimhood of live-in caregivers is framed in relation to a government that is failing to regulate workplace practices and protect a vulnerable migrant worker group, instead recognizing them only through their possession of a work permit. They are workers only instead of full human beings (Arat-Koç, 2001) and receive no pension, medical/dental benefits $^{14}$, or RRSP in their temporary status. The nation state itself thus functions as a family with imported live-in caregivers (Macklin, 1994) that treats live-in caregivers with conditional welcoming, or as previously discussed, like one of the family.

The government is further presented as an antagonist in its imposition of restrictions on a vulnerable, subordinate group of people. Recurring language from colonial discourse in descriptions of the LCP as an institutionalized form of "slavery" or "indentured servitude" reinforces this notion:

(1) “These indentured servants are underpaid, overworked, sexually harassed, and discriminated against because they are not covered under our Charter of Rights and Freedoms" (Quarta, 1995).

(2) "The fact that only a minority of them have access to permanent resident status has had some critics likening this disposable work force to modern-day slavery" (Keung, 2013a).

\footnotetext{
${ }^{14}$ Perhaps because Canada is a nation that prides itself on its widely accessible health care system, stories of the victimhood of live-in caregivers and their lack of rights are often tied to (a lack of) medical care. These stories are also dramatic because of their life-or-death scenarios and thus most likely to evoke empathetic responses - if not a concerted and publicly expressed desire for social change - in its readership. The coverage of Juana Tejada's story (discussed elsewhere in the Analysis) is an exemplar of this.
} 
Thus it would seem that with the LCP in Canada, a white Western nation, there are ideological links with past European colonial practices - links that are reinforced through the importation of a work force that has no citizenship rights or protections. This structure of power and subordination is reinforced in the language depicting the power of the Canadian government to decide the fate of a live-in caregiver: for example, "God - and Immigration Minister Diane Finley - has answered Juana Tejada's prayer” (Keung, 2008a). Despite this, "as the nanny experience shows, the promise of eventual citizenship is a powerful incentive to grin and bear otherwise intolerable working conditions" (Walkom, 2009). This motive is so powerful that, after being granted permission to apply for permanent residency, ${ }^{15}$ Tejada says, "This (immigration) decision has given me the strength to keep fighting [terminal cancer]" (Keung, 2008a). Despite their vulnerabilities under the LCP, these caregivers opt into the program in the hope of being one day granted permanent residency by a powerful government imposing restrictive legislative conditions.

\subsubsection{Victims of Employers}

The restrictive legislative conditions of the LCP also expose its workers to high potential of abuse and exploitation under their employers. The invisibility of these workers in the home of their employers is reproduced in their characterizations as silent and softspoken, as well as a perceived inability to speak against abuse for the fear of jeopardizing their immigration status. Before the rise of racialized domestic caregivers in Canada, nannies were often white British women ${ }^{16}$. The character of Mary Poppins epitomizes "the

\footnotetext{
${ }^{15}$ Juana Tejada had already been rejected twice for health concerns and was in the hospital with cancer at this time (Keung, 2008a).

16 The preference for white nannies from European countries shifted as they became more vocal about the conditions of their work environment. It is well documented that racialized women from Third World
} 
original fully-trained British nanny" (Flavelle, 1989). Macklin (1994) argues that "the further the domestic worker departs from the stereotypic image of [British] Mary Poppins (linguistically and physically), the more employers are encouraged to 'compensate' for the apparent deficit by extracting additional labour from the worker" (22), which often leads to mistreatment. Mistreatment includes exploitation; verbal, physical, and sexual abuse; threats of deportation; and trafficking by agencies.

Mistreatment by recruiter agencies and employers are the basis of an investigative report conducted by the Toronto Star, including a high profile "nannygate" scandal involving MP Ruby Dhalla in which she had allegedly abused her Filipina nannies: these narratives serve as "a cautionary [and] unglamorous tale of the nannies who toil, unseen and unheard, in the homes of upper-class Canadians, middle-class Canadians and, unfortunately, some Canadians with no class at all” (Cohn, 2009). The Ruby Dhalla scandal $^{17}$ helped catalyze more news content on the LCP at the time that it was headlining news in 2009 and raised awareness of live-in caregivers as potential victims of their employers. Coverage like this also challenges and deconstructs issues of illegality, sharpening the sense of wrongdoing of Canadian Ruby Dhalla and mitigating the fact that her foreign Filipina caregivers were working without the proper permits. The emphasis instead is on Dhalla, who, as one of her caregivers stated, "'wanted a slave, not a caregiver'” (Brazao, 2009b). The caregivers were victims left with no choice.

countries are generally more accepting of those same conditions due to (1) similar work conditions in the Middle East where most start working before moving to Canada under the LCP, and (2) higher stakes involved in the desire for permanent residency in Canada (Schecter, 1998).

${ }^{17}$ Similarly, stories following an individual's experience or crisis within the LCP, such as the story of Juana Tejada, would spark an increase in news content and editorial material of the LCP in general. The Toronto Star's special investigation of recruitment agency abuses also saw an increase in news articles and letters to the editor. 


\subsubsection{Victims of the 'Canadian Dream'}

Additionally, live-in caregivers are presented as victims of an idealized vision of Canada, the "land of milk and honey" (Brazao \& Cribb, 2009b). In the Toronto Star, live-in caregivers are consistently presented as hopeful about the opportunity that the LCP gives them and the promise the program holds for a 'better life': "To many, our Live-in Caregiver Program represents their only hope of immigrating to Canada and leaving behind a life of abject poverty" (Fabregas, 2010). The dream is a narrative of being rescued by obtaining “coveted Canadian citizenship" (Walkom, 2009). In this discourse, these imaginings of an idealized life in Canada are characterized as being lure into a trap. The language of ensnarement appears explicitly in at least three articles ${ }^{18}$ :

(1) "Manuel, 39, was lured to Canada by the federal Live-in Caregiver Program” (Brazao, 2008).

(2) "Four months after being lured to Canada, housed in a basement and pressured by a nanny recruiter to work illegally, Filipina Joelina Maluto summoned the courage to take back her life" (Brazao \& Cribb, 2009a).

(3) "Federal Immigration Minister Jason Kenney announced last week he is working on a 'robust package of measures to crack down on bogus immigration consultants,' who lure foreign workers to Canada with fake job contracts" (Brazao, 2009c).

In each case, the end result suggests deception and disenchantment. The danger of these accounts is that "those who testify to loss and suffering can be simplified, de-individualized, and contained within narratives of victimhood" (Pratt, 2012, p. 81) in such a way that "victim" becomes an all-encompassing characterization or identity for live-in caregivers.

\footnotetext{
${ }^{18}$ Note, however, that these articles are authored by the same Toronto Star writer.
} 
This makes the need for an approach to activism (and the use of activist language) that emphasizes the caregivers' agency and complex humanity even more urgent.

\subsection{Filipina Live-In Caregivers as Activists}

Least frequently, live-in caregivers are presented in the Toronto Star as activists working to secure their own rights within the LCP. This is where the live-in caregivers gain a sense of agency in public space and the power of their voices, once unheard, is championed.

\subsubsection{Caregivers Advocating for Rights of Caregivers}

As has been evidenced so far in the Analysis, 'media stereotypes emphasize the centrality of family to Filipino community as well as their passivity and invisibility' (Pratt, 2012, p. 73). While there are stereotypic tendencies in the media in portraying Filipina women as quiet, passive, and obedient, there are also instances in which caregivers are portrayed as actively fighting against the exploitation of Filipina workers. The smaller frequency count of this narrative, however, can be interpreted as a reflection of the public' limited perceptions of the caregivers' agency, or that stories detailing the problems caregivers encounter with program structure and government policies and their hardships and struggles are simply deemed more newsworthy. However, whenever stories about the caregivers' activism occur, the language used to describe the caregivers is intended to be awe-inspiring and powerful, and marks a shift in emphasis from Filipina invisibility in the domestic realm of the home to Filipina visibility, voice, and agency in public space. Even Juana Tejada's story, ${ }^{19}$ which can be easily co-opted by efforts to romanticize the

\footnotetext{
${ }^{19}$ Her story is documented eighteen times in the database. See articles 25, 27, 32-33, 35-38, 41, 45-46, 52, 64, 90, 93, 97-98, 111 in the Appendix.
} 
caregivers' plight and so hamper real social justice interventions, was reclaimed by caregiver activists so that she became "a symbol for changes to the rights of the often voiceless, faceless live-in caregivers toiling at low wages for looking after Canada's young and old" (Keung, 2008b). A law called the "Juana Tejada Law20" was named after her (Kamel, 2008), and a Philippine TV-drama series re-creating her life as a live-in caregiver (Keung, 2011b) was created. Whether by conscious design or inadvertently, the Toronto Star participated in co-constructing Juana Tejada's legacy as an icon for the caregiver activist movement in Canada.

\subsubsection{The Canadian Audience as Activists}

Emerging from this theme of activism come two prevalent subcategories: the Canadian audience and the Toronto Star newspaper fulfilling roles of activists ${ }^{21}$. These news articles employ a strategy of implicating Canadian audiences in the testimonies of live-in caregivers ${ }^{22}$ in a way that encourages social activism and responsibility. The inclusion of these subcategories in this discussion is justified by their prominence in the newspaper articles and the meaningful interaction generated between them and the narrative of Filipina nannies as activists.

Readers of the Toronto Star respond to the news coverage of live-in caregivers in the form of letters to the editor, opinion editorials, and even comments on thestar.com. All

\footnotetext{
20 The "Juana Tejada Law" would "entail an amendment to the Immigration and Refugee Protection Act that would help guarantee the rights of medically inadmissible but otherwise qualified foreign caregivers living in Canada" (Kamel, 2008). This campaign was led by unions and immigrant activist groups.

${ }^{21}$ Note that these two sub-categories were not included in the coding of the 'activist' category in Table 1, which only specifically consists of instances in which live-in caregivers appear as activists.

${ }^{22}$ See Pratt, 2012 for this connection between live-in caregivers and the Canadian audience.
} 
news participants are social actors (van Dijk, 1988), and even more so when they speak up about what kinds of decisions and actions the government should take, and how other Canadians should feel and react:

(1) "Foreign domestics need our help" (Tesher, 1996).

(2) "I would like to add my name to the call for regulation of nanny agencies ..." (Hynes, 2009).

(3) "All Canadians should be outraged that this injustice continues to take place in a province and country such as ours" (Ponting, 2009).

These demands for action seek to take power from governmental authority and give it to other members of Canadian society. They redeem the vices of Canadian society (particularly the government and employers) through their recognition of the value of these live-in caregivers and their upholding of notions of national responsibility and demands for humanitarian action in a liberal society.

The narrative of rescue and redemption is complete here: live-in caregivers are subordinate and meek foreigners who feel they are being rescued by the opportunity the LCP presents. They are also victims lured into the trap of the Canadian Dream and subject to the exploitation and abuse of the government and employers. An altruistic and inclusive Canadian society redeems these narratives through speaking up about the rights of the workers - second-handedly giving voice to the voiceless and power to the powerless. However, it is important to remember, as Pratt (2012) points out, that the "capacity for a wider public to empathize - including and possibly especially with those we perceive to be different from ourselves - can be self-affirming in ways that stabilize existing social hierarchy" (p. 80). That is, these Canadian readers occupy a position of privilege in relation 
to the caregivers themselves ${ }^{23}$ and so have the space and opportunity to voice their opinions about, and make demands of, the government. This difference in power underpins current systems of representation in Western media and reflects on how the West perceives itself: "For if the Rest was necessary for the political, economic, and social formation of the West, it was also essential to the West's formation both of its own sense of self - a 'western identity' - and of western forms of knowledge” (Hall, 2007, p. 225). Here, "western identity" is dual in nature: on one hand, the LCP is a Canadian institution of "enslavement" that victimizes subaltern workers, and on the other hand, Canadians take activist roles in a "rescue and redemption" narrative arc by speaking up for the rights and improved status of these workers. In this way, the LCP "says a lot about the Philippines. But also about Canada and Canadians" (Cohn, 2009).

\subsubsection{The Toronto Star as Activist}

The coverage of live-in caregivers also says a lot about how the media may take on an activist role through investigative journalism. The Toronto Star conducted a two-part investigative series - published on March $14^{\text {th }}$ and $15^{\text {th }}$ of $2009^{24}$ - exposing the mistreatment of live-in caregivers by recruiter agencies. Later articles dealing with the LCP make constant referrals back to this investigation ${ }^{25}$, situating each article within its framework of victimization. This discursive technique validates the Toronto Star as a

\footnotetext{
${ }^{23}$ Note that Filipina caregivers are interviewed and make appearances in articles demanding recognition from the Canadian government. However, no guest news items or letters to the editor are written (or submitted) by Filipina caregivers or activists to the Toronto Star. This is a reminder that "the symbolic power of the journalistic elite contributes at the same time to the reproduction of the conditions of socioeconomic or political power" (van Dijk, 1988, p. 155).

${ }^{24}$ See articles 46 and 47 in the Appendix.

${ }^{25}$ For example, "[on a meeting by Ontario officials on the mistreatment of live-in caregivers] The meeting was held ... after a Star investigation exposed widespread abuse in a program that allows Canadians to hire foreign caregivers to look after children, the elderly or people with disabilities" (Brazao, 2009b).
} 
critical and central newspaper, as well as social activist exposing abuse and championing human rights, and furthermore "rescuing" victims of the LCP. Later opinion letters also achieve the same effect: "I applaud the Star for its excellent series and urge you to continue your investigations and coverage of migrant workers who are being exploited by our, dare I say it, racist and employer-driven, immigration system" (Ponting, 2009). However, it also runs the risk of pathologizing all live-in caregivers as victims and homogenizing their experiences in a singular conceptualization. This narrative is expanded, however, when more investigative work conducted on the Ruby Dhalla scandal applauds the three nannies for taking action about their situation. The newspaper then simultaneously supports the caregivers' agency and continues its own agenda to speak for and about the caregivers: "The Star learned of the allegation and began its own probe," says Brazao (2009b). Thus the Toronto Star's actions demonstrate that "[d]iscourses are not reducible to class interests, but always operate in relation to power - they are part of the way power circulates and is contested" (Hall, 2007, p. 205).

Colonial and postcolonial discourses do not exist solely in the past, and the ideological dimensions of Western expansion continue to inform existing media discourses. As Hall (2007) notes, discourses do not stop abruptly even as they encounter new circumstances. Discourses today "often carry many of the same unconscious premises and unexamined assumptions in their blood-stream" (p. 221). However, raising awareness to this fact allows media practitioners to add to and shift existing discourses about live-in caregivers so that their value to, and as participants in, Canadian society can be properly acknowledged. 


\section{CONCLUSION}

The media is a powerful tool and disseminator of social ideologies and discourses. A mainstream newspaper like the Toronto Star plays an influential role in framing discussions and debates about immigration and immigration policy in Canada. Widely circulated, the informs readers about current events, issues, and topics, and guides readers on how to interpret and make sense of their world by employing specific language and images to frame the stories they tell. Even when vilifying the government and criticizing the mistreatment of LCP workers, the Toronto Star's attempts at garnering support and sympathy for LCP workers positions the latter in subtle and complex ways as an 'Other' to its Canadian readers. In the newspaper's articles, LCP workers are in large part characterized by their "difference" from a Canadian norm. Thus, while Canadian values of inclusivity are upheld in the explicit language of these articles, there is an implicit level of exclusion as well.

An overarching narrative about Filipina LCP workers and Canadian society can be reconstructed from the Toronto Star news stories: LCP workers are foreign mothers and labourers coming from the Philippines in order to provide for their families back home. While they are allowed in our country and in our homes, the state of that 'welcome' is vague and dual in nature, positioning the caregivers in a space between being included and being excluded.

\subsection{Discussion and Implications}

In the Toronto Star, LCP workers have a rather ambivalent presence in Canadian society being neither fully included nor excluded, and being simultaneously visible and invisible. They are made visible and invisible at the same time under the media gaze by 
being seen only through a specific lens (Hall, 2007). Thus while under the gaze of the Canadian state and public through media attention and coverage of their stories, particular emphases in the narratives about Filipina nannies feed into common stereotypes and so reinforce the social inequalities experienced by these LCP workers. It is interesting to note that while the media makes Filipina workers in the LCP more visible, the latter continues to be invisible in a number of ways in the stories that this same newspaper tells.

The work of critical discourse analysis allows the researcher to be cognizant of social inequality and the relationship between discourse and power. It is the first step in equipping oneself with the necessary resources to understand and challenge the representational strategies employed by the media. This study brings to the reader's attention the discourse of difference employed in the newspaper's representation of LCP workers, and consequently points to the need to empower this group of workers. With this knowledge, recommendations for social action and change can be promoted.

\subsection{Recommendations}

Several initiatives have been undertaken to aid workers in the LCP, such as the proposal of a "nanny blacklist" 26 for abusive agencies and the establishment of a "nanny hotline"27 following the investigative series conducted by the Toronto Star. The hotline is also promoted in many subsequent Toronto Star articles, particularly during the coverage of Ruby Dhalla's "nannygate" scandal, and exemplifies one of the real social justice outcomes news coverage can have.

\footnotetext{
26 See article 55 in the Appendix.

27 See article 62 in the Appendix.
} 
As indicated in this study, the news media can play an important role in bringing public awareness to important and pressing issues pertinent to Canadian programs like the LCP, and critically exposing the forms of abuse that they perpetuate. As such, media practitioners should be more aware of and attentive to the ways language is used to inform the public and create or challenge dominant societal ideologies, particularly those of race, gender, and class.

This study has focused on the content of news articles in a mainstream Canadian newspaper. The establishment of independent ethnic and community-based newspapers and/or newsletters also plays a crucial role in challenging prevailing discourses and producing counter-ideologies. These alternative forms of media also provide information on any community resources, such as workshops and seminars, which allow LCP workers to network and seek support. Increasing awareness through various alternative media sources also allows LCP workers to build networks, communities, and organizations that help lessen or end altogether the well-documented feelings of isolation they tend to experience (Arat-Koç, 2001; Parreñas, 2001). Such networks need not be limited to the Filipino-Canadian community: linking networks with other minority groups, such as Caribbean domestics for example, could enrich the dialogue and discourse surrounding racialized and gendered women working in the LCP as well as strengthen a sense of solidarity and community among and within the various groups of LCP workers, and between the caregivers and the larger Canadian society.

The need for increased awareness and larger community networks is also relevant to the experience of children of live-in caregivers. These children must cope with the effects 
of long-term family separation and, where family sponsorship is successful, with the stresses that attend reunification and settling into a new country. Media coverage of Filipino youths ${ }^{28}$ in Canada tends to be limited almost exclusively to their participation in acts of violence and the high drop-out rates - with little to no stories of their successes or achievements. These children also need representation, role models, and community.

On the governmental level, it is recommended in much of the academic literature and the Toronto Star articles that LCP workers should immediately be granted right to permanent status (Arat-Koç, 2001; Fabregas, 2010; Spitzer \& Torres, 2008; Walkom, 2009). This would give live-in caregivers access to social rights services that would ease their integration into Canadian society as protected citizens and workers. Such entitlement to this legal right is championed in a well-known slogan of the migrant worker activist movement: "good enough to work, good enough to stay". It would also mitigate against acts of racial, gendered, and class-based discrimination that are common in the program ${ }^{29}$ by allowing caregivers equitable access to Canadian citizenship rights. Together, mass media and Canadian immigration policy participate in the social construction of live-in caregivers in ways that have real effects on their lives and livelihoods.

\subsection{Future Research and Reflection}

The focus of this study has been media representations and narratives of Filipina workers in the Live-in Caregiver Program. Further investigation and discussion of Filipinos in general in the Toronto Star (and/or other newspapers) would be another avenue of

\footnotetext{
${ }^{28}$ See Catungal, 2012 and Kelly, 2006. See article 14 and 124 in Appendix.

${ }^{29}$ See Spitzer \& Torres, 2008.
} 
research to explore related forms of stigmatization this minority community faces. A recurring theme in some of the literature and articles on Filipino-Canadian migrants is the struggle to find identity ${ }^{30}$. For Filipinos who are not even necessarily LCP workers, such as Filipina women in general and their children, there are feelings of shame associated with stereotypes that cast them seemingly in an all-encompassing way as domestic caregivers.

Conducting research on the database for the Toronto Star uncovered many articles about the problems of youth violence involving Filipinos in Canada. Examination of the language and images employed in these articles could illuminate the findings from the research conducted on articles about Filipina LCP workers, thus allowing for an interconnected and more complete story of Filipino identity as constructed by the Canadian media and circulating in the popular imagination to emerge.

On that note, women and youth issues appear to be the dominant concerns in coverage of the Filipino-Canadian community in Toronto. There is a lack of engagement with the immigration and settlement experiences of Filipino men, particularly the husbands of LCP workers, both in the academic research and in media news outlets. This is another area that needs to be addressed.

Immigration discourses prevalent in mainstream Canadian media operate in, and in relation, to those coming out of the nation's political economy (van Dijk, 1988). This is especially relevant given the appearance of a more recent article in the Toronto Star outside of the timeframe of data collection for this study. The article (part of a series) concerns the political rhetoric of Employment Minister, Jason Kenney, regarding LCP workers: Kenney accuses Filipina workers of abusing and "mutating" the program into a

\footnotetext{
${ }^{30}$ See articles 23, 29, 53, and 100 in the Appendix.
} 
family reunification project and threatens to bring an end to the LCP as a pathway to permanent residency ${ }^{31}$. Juxtaposing the discourses at work within the news media with those circulated by politicians would provide some insight into the degree to which dominant ideologies concerning citizenship and non-citizenship, as well as representations of temporary foreign workers, and ideas about illegality in immigration are reinforced or contested.

In this regard parallels can also be made with the Caribbean domestics in the FDM whose representation in the media and public discourse shifted from that of the "agreeable and affectionate mammy" to images of the Caribbean woman as "aggressive, incompetent, and cunningly criminal'"' (Schecter, 1998, p. 122). Such a project would provide some insight into the ebbs and flows in the history of Canadian immigration practice and the relationship of that institution with non-white and non-European countries.

As mentioned in the previous section, ethnic and community-based media and organizations play a crucial role in developing counter-narratives. Community $\operatorname{arts}^{32}$ are also another medium through which minority community members can engage in selfdefinition and explore, resist, and challenge the cultural constructions of themselves that appear in mainstream media discourses. Such artistic endeavours bring together those with shared experiences and harness the power of the imagination to create new and more

\footnotetext{
${ }^{31}$ See Keung, N. (2014, July 22). Filipino Canadians fear end of immigrant dreams for nannies. Toronto Star. Retrieved from

http://www.thestar.com/news/immigration/2014/07/22/filipino_canadian_fear_end_of_immigrant_dreams _for_nannies.html.

32 The existence of some plays organized by the Filipino community and LCP networks in Toronto have been documented in the database of this study. See Appendix articles 03 ("If My Mother Could See Me Now"), 17 ("Mis Orient[ed]"), and 97 ("Future Folk"). Additionally, a Filipino TV drama filmed an episode in the GTA about Juana Tejada in article 111.
} 
empowering narratives. Participating in and co-constructing their own stories in a creative fashion can be liberating and therapeutic for LCP workers while further bringing to public attention the situations they face in Canada. One upcoming project to highlight is a collaborative comic book project between Toronto-based artists and Filipina caregivers entitled Kwentong Bayan: Labour of Love33, which is scheduled to be released in 2015. Comparing the discourses circulating within mainstream with those created by alternative media sources is a viable topic for future research.

There are numerous types of media to explore when analyzing the production of narratives. The internet is a dauntingly large and evolving postmodern space in terms of the kinds of narrative constructions, de-constructions, and re-constructions it enables. The de-centering possibilities afforded by the internet can help disassemble dominant mainstream narratives and challenge deeply embedded ideologies. Research on how people participate to express their identities and own narratives on the internet - through various websites, forums, videos, pictures, and social media - can add to current discussions of postcoloniality, as well as discussions about visibility and invisibility. Research work of this nature is fundamental in realizing the power of language and structures of dominance in society, challenging norms, and catalyzing social change for a better and more inclusive Canadian society in which all may participate and contribute.

${ }^{33}$ The English translation of Kwentong Bayan is "community stories". More information on this project can be found at http://www.lcpcomicbook.com/. 


\section{APPENDIX}

\section{News Articles on Filipina Nannies in the Live-In Caregiver Program in the Toronto Star Coding Sheet}

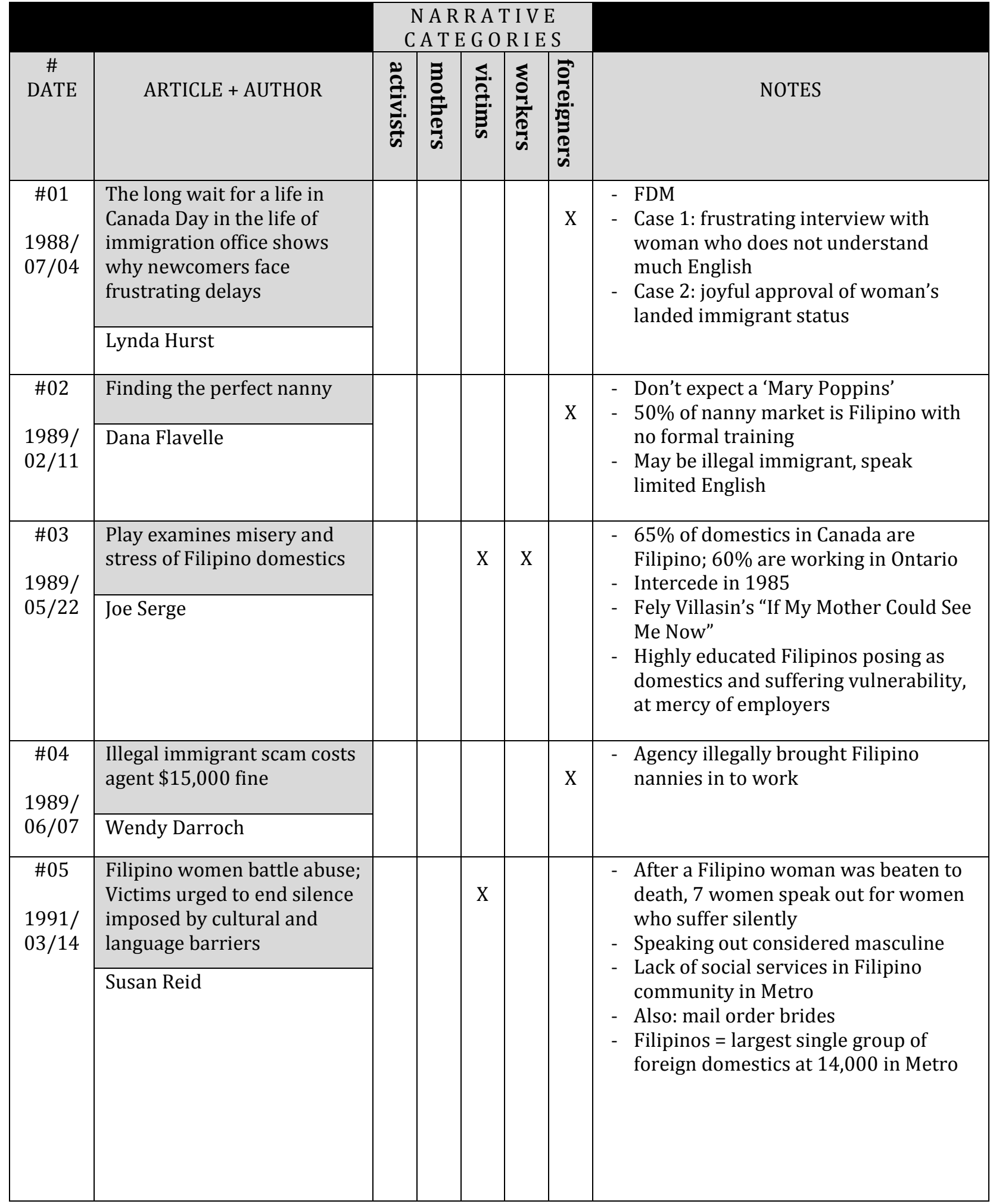




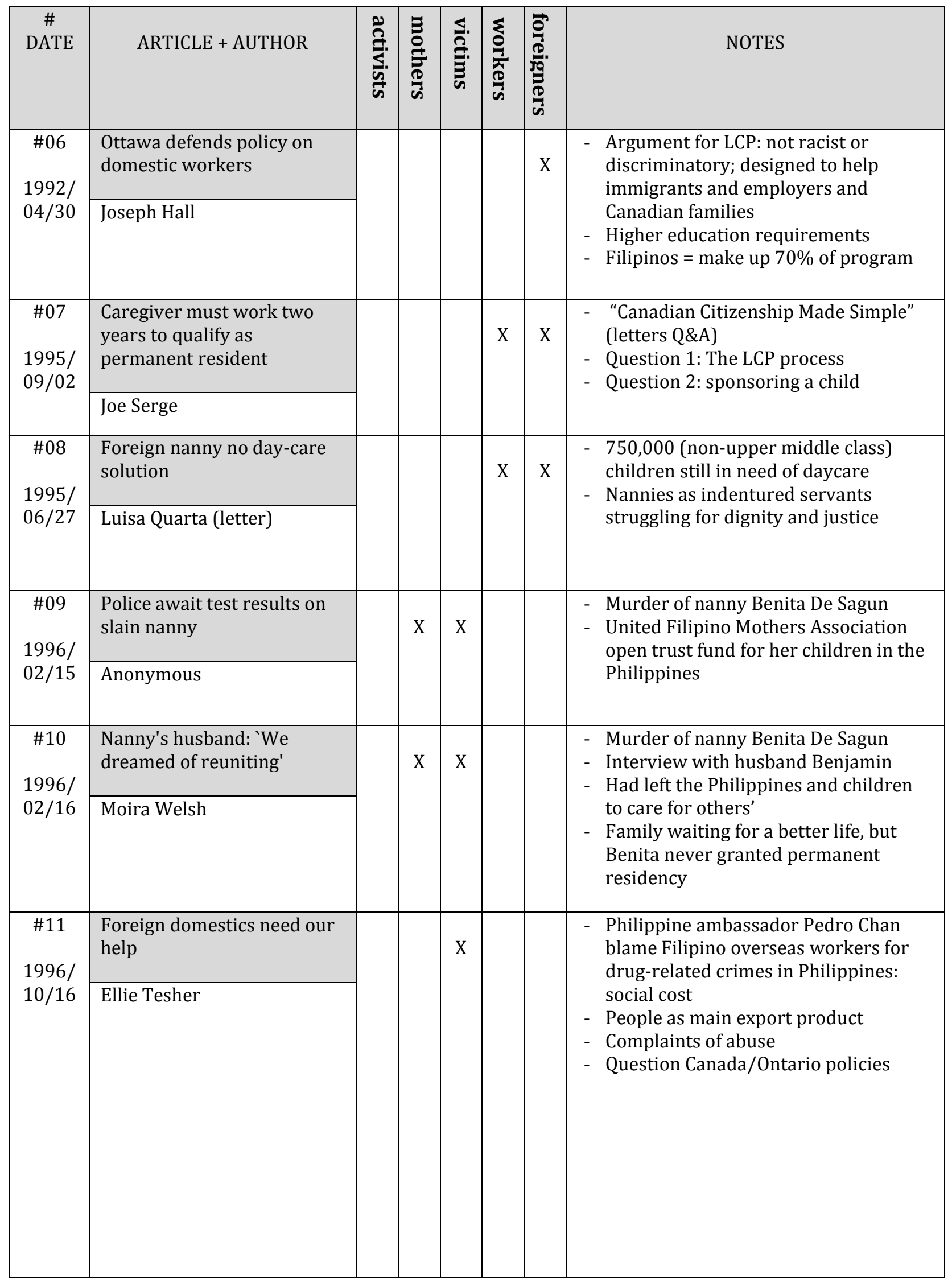




\begin{tabular}{|c|c|c|c|c|c|c|c|}
\hline $\begin{array}{c}\# \\
\text { DATE }\end{array}$ & ARTICLE + AUTHOR & 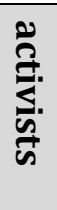 & 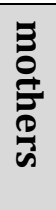 & $\stackrel{\leq}{\stackrel{S}{\Xi}}$ & 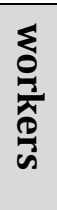 & 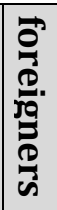 & NOTES \\
\hline \multirow{2}{*}{$\begin{array}{l}\# 12 \\
1999 / \\
03 / 29\end{array}$} & $\begin{array}{l}\text { Program helps them get } \\
\text { mental health care }\end{array}$ & & & \multirow[t]{2}{*}{$\mathrm{X}$} & & & \multirow{2}{*}{$\begin{array}{l}\text { - Tiring domestic work and feelings of } \\
\text { isolation } \\
\text { - Seeking psychiatric help and using } \\
\text { services when mentally strained } \\
\text { - Centre for Addiction and Mental } \\
\text { Health }\end{array}$} \\
\hline & Natalia Williams & & & & & & \\
\hline \multirow{2}{*}{$\begin{array}{l}13 \\
1999 / \\
08 / 19\end{array}$} & $\begin{array}{l}\text { Where is support for those } \\
\text { who play by the rules? }\end{array}$ & & & \multirow[t]{2}{*}{$\mathrm{X}$} & \multirow[t]{2}{*}{$\mathrm{X}$} & \multirow[t]{2}{*}{ X } & \multirow[t]{2}{*}{$\begin{array}{l}\text { - Arbitrariness of immigration officers } \\
\text { in denying candidates for LCP } \\
\text { - Versus illegal immigrants }\end{array}$} \\
\hline & Bruce Gates & & & & & & \\
\hline \multirow{2}{*}{$\begin{array}{l}\# 14 \\
2001 / \\
08 / 28\end{array}$} & $\begin{array}{l}\text { Who looks after the nanny's } \\
\text { children? }\end{array}$ & & \multirow[t]{2}{*}{$X$} & & & \multirow[t]{2}{*}{$\mathrm{X}$} & \multirow{2}{*}{$\begin{array}{l}\text { - Children being 'abandoned', grow up } \\
\text { not knowing mothers thus extra } \\
\text { difficulty in adjusting to life in Canada } \\
\text { - linked to youth violence } \\
\text { - } 80 \% \text { of domestics from Philippines } \\
\text { - 'Canadian government is responsible } \\
\text { for destroying families of women from } \\
\text { poor countries' }\end{array}$} \\
\hline & Anonymous & & & & & & \\
\hline \multirow{2}{*}{$\begin{array}{l}\# 15 \\
2002 / \\
04 / 25\end{array}$} & $\begin{array}{l}\text { Caregivers have made a } \\
\text { difference }\end{array}$ & \multirow[t]{2}{*}{$\mathrm{X}$} & & & \multirow[t]{2}{*}{$X$} & & \multirow{2}{*}{$\begin{array}{l}\text { - Proposal of a formal Nanny's Day, 'a } \\
\text { celebration of the domestic workers } \\
\text { who provide families with security } \\
\text { and comfort' } \\
\text { - As hardworking women }\end{array}$} \\
\hline & Ellie Tesher & & & & & & \\
\hline \multirow{2}{*}{$\begin{array}{l}\text { \#16 } \\
2002 / \\
07 / 21\end{array}$} & $\begin{array}{l}\text { Sending money home is big } \\
\text { business }\end{array}$ & & \multirow[t]{2}{*}{$\mathrm{X}$} & & & \multirow[t]{2}{*}{$\mathrm{X}$} & \multirow{2}{*}{$\begin{array}{l}\text { - Sending foreign remittances } \\
\text { - Not terrorists; mostly caregivers } \\
\text { engaging in transnational behaviour } \\
\text { - 'just a new Canadian with a foot in two } \\
\text { different lands' }\end{array}$} \\
\hline & Ross Oakland & & & & & & \\
\hline \multirow{2}{*}{$\begin{array}{l}\# 17 \\
2003 / \\
05 / 25\end{array}$} & $\begin{array}{l}\text { Beauty pageant play is only } \\
\text { skin deep }\end{array}$ & & & & & \multirow[t]{2}{*}{$\mathrm{X}$} & \multirow{2}{*}{$\begin{array}{l}\text { - Review of play 'Mis Orient(ed)' about } \\
\text { Filipino stereotype role as } \\
\text { caregiver/housekeeper, what it means } \\
\text { to be a modern Filipino woman }\end{array}$} \\
\hline & Robert Crew & & & & & & \\
\hline \multirow{2}{*}{$\begin{array}{l}\# 18 \\
2004 / \\
10 / 30\end{array}$} & $\begin{array}{l}\text { Many employers, agencies } \\
\text { abuse live-in work program }\end{array}$ & & & $\mathrm{X}$ & $\mathrm{X}$ & $\mathrm{X}$ & \multirow{2}{*}{$\begin{array}{l}\text { - Star examination of LCP system as } \\
\text { exploitation rather than 'response to } \\
\text { labour market needs' } \\
\text { - The promise of permanent residency } \\
\text { status } \\
\text { - Especially live-in aspect }\end{array}$} \\
\hline & Scott Simmie & & & & & & \\
\hline
\end{tabular}




\begin{tabular}{|c|c|c|c|c|c|c|c|}
\hline $\begin{array}{c}\# \\
\text { DATE }\end{array}$ & ARTICLE + AUTHOR & 芯. & 疍 & 方: & $\frac{\sum}{\substack{\frac{1}{2} \\
\frac{1}{3}}}$ & 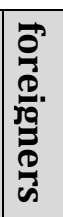 & NOTES \\
\hline $\begin{array}{l}\# 19 \\
2004 / \\
11 / 02\end{array}$ & $\begin{array}{l}\text { Nannies to be protected, } \\
\text { Sgro vows; Caregiver } \\
\text { program under review, } \\
\text { minister says 'I don't want } \\
\text { anyone being exploited' in } \\
\text { Canada } \\
\begin{array}{l}\text { Melissa Leong and Scott } \\
\text { Simmie }\end{array}\end{array}$ & & & $X$ & & $X$ & $\begin{array}{l}\text { - Reveal how some nannies are } \\
\text { exploited by unregulated agencies; } \\
\text { financial and sexual abuse by } \\
\text { employers } \\
\text { - "no one should be afraid of losing their } \\
\text { immigration status" } \\
\text { - Translation of employment standards } \\
\text { brochures into Filipino } \\
\text { - Charge that Ottawa has failed to } \\
\text { protect this vulnerable group of } \\
\text { migrants - 'Canadian values' } \\
\text { - News in Philippines: Canada should ge } \\
\text { rid of LCP }\end{array}$ \\
\hline $\begin{array}{l}\# 20 \\
2004 / \\
11 / 02\end{array}$ & $\begin{array}{l}\text { Time to regulate caregiver } \\
\text { program }\end{array}$ & & & & $X$ & X & $\begin{array}{l}\text { - Canada must clean up program of } \\
\text { indentured servitude and abuse } \\
\text { - Chance to work in Canada is a dream; } \\
\text { single goal of permanent residency } \\
\text { - For many, LCP operates as it should - } \\
\text { but much abuse = government fail to } \\
\text { regulate policies it creates } \\
\text { - Recommendation: for licensing } \\
\text { regime, Ontario should compel } \\
\text { agencies to charge employers not } \\
\text { caregivers for services } \\
\text { - Recommendation: ensure caregivers } \\
\text { know their rights }\end{array}$ \\
\hline $\begin{array}{l}\# 21 \\
2004 / \\
12 / 12\end{array}$ & $\begin{array}{l}\text { Nannies seek program } \\
\text { changes; Groups want 'live- } \\
\text { in' requirement scrapped } \\
\text { Position paper lays out } \\
\text { 'human right issues' } \\
\text { Scott Simmie and Melissa } \\
\text { Leong }\end{array}$ & $X$ & & & & & $\begin{array}{l}\text { - Nannies desire change: live-in aspect, } \\
2 \text { years of work in } 3 \text { year period } \\
\text { - Many have positive experiences, } \\
\text { others are financially exploited }\end{array}$ \\
\hline $\begin{array}{l}\# 22 \\
2005 / \\
03 / 17\end{array}$ & $\begin{array}{l}\text { Nanny tells of sex attack; } \\
\text { Told her employer 'No, stop } \\
\text { it' Man on trial for sexual } \\
\text { assault } \\
\text { Gail Swainson }\end{array}$ & & $\mathrm{X}$ & $\mathrm{X}$ & & & $\begin{array}{l}\text { - 40-year-old woman had come to work } \\
\text { in Canada for future of her two } \\
\text { children back in Philippines } \\
\text { - } \text { Alleged assault from male employer }\end{array}$ \\
\hline
\end{tabular}




\begin{tabular}{|c|c|c|c|c|c|c|c|}
\hline $\begin{array}{c}\# \\
\text { DATE }\end{array}$ & ARTICLE + AUTHOR & ڤั. & 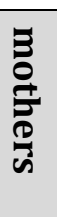 & $\stackrel{\leq}{\grave{g}}$ & 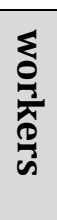 & 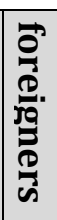 & NOTES \\
\hline \multirow{2}{*}{$\begin{array}{l}\# 23 \\
2005 / \\
11 / 28\end{array}$} & $\begin{array}{l}\text { Filipino centre unites } \\
\text { generations }\end{array}$ & & & & \multirow[t]{2}{*}{$\mathrm{X}$} & \multirow[t]{2}{*}{$\mathrm{X}$} & \multirow{2}{*}{$\begin{array}{l}\text { - Kapisanan Centre being fundraised for } \\
\text { since 1980s } \\
\text { - struggle to find identity in Canada: } \\
\text { feelings of shame because came as } \\
\text { domestic workers = treated as lower } \\
\text { class people despite qualifications }\end{array}$} \\
\hline & Nicholas Keung & & & & & & \\
\hline \multirow[t]{2}{*}{$\begin{array}{l}\# 24 \\
2007 / \\
02 / 15\end{array}$} & $\begin{array}{l}\text { Bright spark from the } \\
\text { Philippines; Activist with a } \\
\text { Sorbonne degree battled } \\
\text { Marcos, then fought for } \\
\text { domestic workers }\end{array}$ & \multirow[t]{2}{*}{$\mathrm{X}$} & & & & & \multirow[t]{2}{*}{$\begin{array}{l}\text { - activist Fely Villasin death from cancer } \\
\text { - mentored other live in caregivers, } \\
\text { many of whom found work in her } \\
\text { organization }\end{array}$} \\
\hline & Catherine Dunphy & & & & & & \\
\hline $\begin{array}{l}\# 25 \\
2007 / \\
03 / 02\end{array}$ & $\begin{array}{l}\text { 'Falling through the cracks' } \\
\text { Cancer threatens nanny's life } \\
\text { and her dream of permanent } \\
\text { status; Sick Filipina who } \\
\text { completed caregiver } \\
\text { contract left without OHIP or } \\
\text { residency status } \\
\text { Nicholas Keung }\end{array}$ & $\mathrm{X}$ & & $\mathrm{X}$ & & $\mathrm{X}$ & $\begin{array}{l}\text { - Juana Tejada's story } \\
\text { - Filipino activist claims her health } \\
\text { situation holds up her permanent } \\
\text { residency application } \\
\text { - Problem of being caught in between, } \\
\text { 'transition of status' } \\
\text { - Continued to work minimum wage at } \\
\text { Tim Horton's; still needed to send } \\
\text { money home }\end{array}$ \\
\hline $\begin{array}{l}\# 26 \\
2007 / \\
03 / 02\end{array}$ & $\begin{array}{l}\begin{array}{l}\text { How Canada's Live In } \\
\text { Caregiver Program Works }\end{array} \\
\text { Anonymous }\end{array}$ & & & & $\mathrm{X}$ & $\mathrm{X}$ & $\begin{array}{l}\text { - 'offers unique opportunity to } \\
\text { otherwise ineligible participants' } \\
\text { - To benefit both caregiver and } \\
\text { employer } \\
\text { - } \text { Focus on permanent residency status }\end{array}$ \\
\hline $\begin{array}{l}\# 27 \\
2007 / \\
03 / 09\end{array}$ & $\begin{array}{l}\text { Nanny awarded medical } \\
\text { coverage; Cancer treatment } \\
\text { was delayed after woman } \\
\text { deemed ineligible for OHIP } \\
\text { Nicholas Keung }\end{array}$ & & & $\mathrm{X}$ & & $\mathrm{X}$ & $\begin{array}{l}\text { - Story of Juana Tejada } \\
\text { - Review of her case reaffirmed } \\
\text { eligibility for OHIP } \\
\text { - Had been stuck in a 'catch-22' } \\
\text { - 'when she gets her health back, she } \\
\text { can also realize her dream and get her } \\
\text { immigration status' }\end{array}$ \\
\hline
\end{tabular}




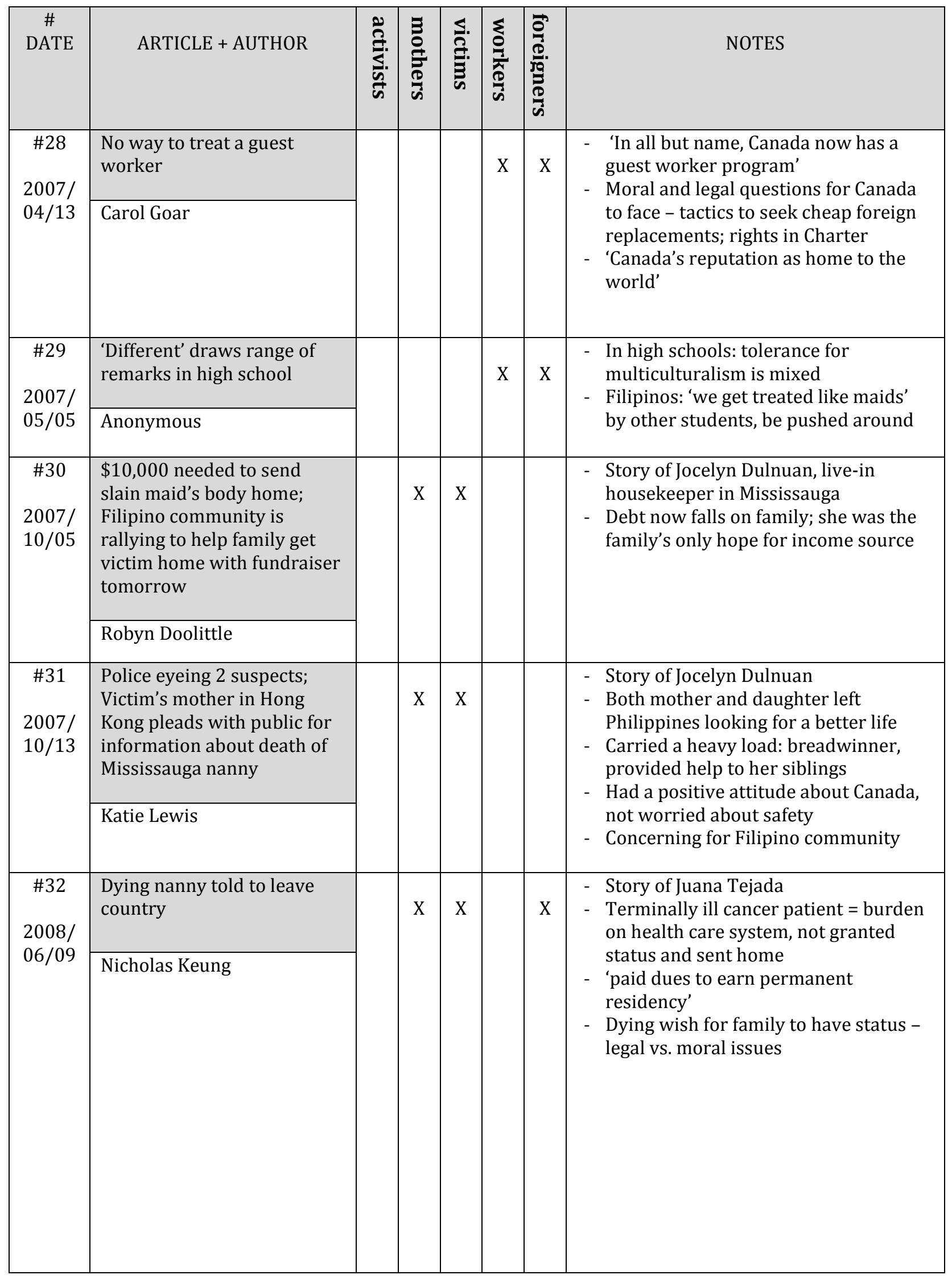




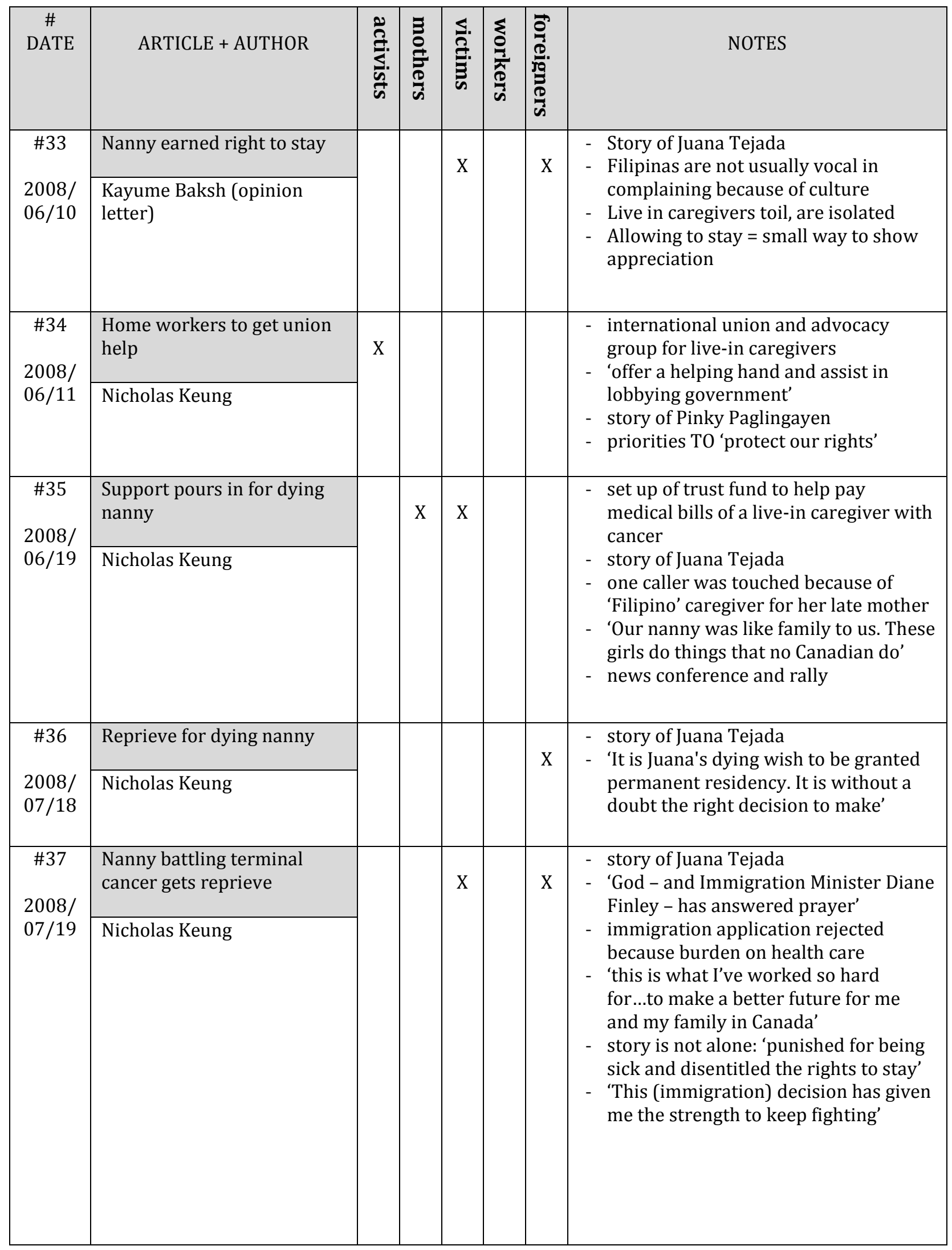




\begin{tabular}{|c|c|c|c|c|c|c|c|}
\hline $\begin{array}{c}\# \\
\text { DATE }\end{array}$ & ARTICLE + AUTHOR & 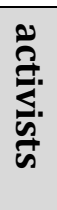 & 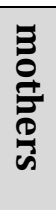 & 方. & $\frac{\sum}{0}$ & 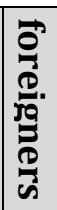 & NOTES \\
\hline \multirow{2}{*}{$\begin{array}{c}\text { \#38 } \\
\text { 2008/ } \\
08 / 26\end{array}$} & $\begin{array}{l}\text { Dying nanny wants law } \\
\text { change }\end{array}$ & \multirow[t]{2}{*}{$\mathrm{X}$} & & \multirow[t]{2}{*}{$\mathrm{X}$} & & \multirow[t]{2}{*}{$\mathrm{X}$} & \multirow{2}{*}{$\begin{array}{l}\text { - story of Juana Tejada } \\
\text { - after strong public support, campaign } \\
\text { proposing a "Juana Tejada Law" - } \\
\text { amendment to the Immigration and } \\
\text { Refugee Protection Act } \\
\text { - 'I dream of a society that gives value to } \\
\text { its people who create its wealth' } \\
\text { - Filipino communities and others } \\
\text { - Olivia Chow: 'They take care of } \\
\text { Canadian children. Working families } \\
\text { - would not survive without them' } \\
\text { - hopes to recover and have a family } \\
\text { - cf. } 2008 / 08 / 27 \text { Advocates, unions } \\
\text { fighting for migrant labourers' rights }\end{array}$} \\
\hline & Deena Kamel & & & & & & \\
\hline \multirow{2}{*}{$\begin{array}{c}\# 39 \\
\text { 2008/ } \\
09 / 22\end{array}$} & $\begin{array}{l}\text { Nanny sent to work as an } \\
\text { underpaid servant }\end{array}$ & & \multirow[t]{2}{*}{$\mathrm{X}$} & \multirow[t]{2}{*}{$\mathrm{X}$} & \multirow[t]{2}{*}{$\mathrm{X}$} & \multirow[t]{2}{*}{$\mathrm{X}$} & \multirow[b]{2}{*}{$\begin{array}{l}\text { - } \text { story of Catherine Manuel } \\
\text { - underpaid as cleaner, servant, } \\
\text { handywoman; not sure if original } \\
\text { employer Brent really exists } \\
\text { - } \text { was lured to Canada by federal LCP - } \\
\text { promised life would be better here } \\
\text { - Like many Filipino women, Manuel } \\
\text { sought work overseas to support } \\
\text { family } \\
\text { - told to keep quiet: working illegally } \\
\text { - expensive placement fees - fraud; } \\
\text { needed for children } \\
\text { - 'coming to Canada thinking this is the } \\
\text { land of opportunity' } \\
\text { - 'right to be treated with respect' } \\
\text { - need for protections: While } \\
\text { Immigration officers are quick to } \\
\text { deport caregivers duped or trafficked } \\
\text { into Canada, they take no action } \\
\text { against the agencies that brought them } \\
\text { in }\end{array}$} \\
\hline & Dale Brazao & & & & & & \\
\hline \multirow[t]{2}{*}{$\begin{array}{c}440 \\
2008 / \\
10 / 24\end{array}$} & $\begin{array}{l}\text { New criteria alarm } \\
\text { immigrants; Radical changes } \\
\text { to immigration process are } \\
\text { dangerous, say some } \\
\text { educated newcomers }\end{array}$ & & & & \multirow[t]{2}{*}{$\mathrm{X}$} & & \multirow[t]{2}{*}{$\begin{array}{l}\text { nurses working as caregivers (de- } \\
\text { skilling) }\end{array}$} \\
\hline & $\begin{array}{l}\text { Lesley Ciarula Taylor and } \\
\text { Nicholas Keung }\end{array}$ & & & & & & \\
\hline
\end{tabular}




\begin{tabular}{|c|c|c|c|c|c|c|c|}
\hline $\begin{array}{c}\# \\
\text { DATE }\end{array}$ & ARTICLE + AUTHOR & 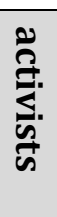 & 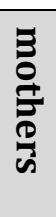 & 彰: & $\frac{\sum}{0}$ & 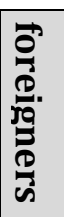 & NOTES \\
\hline \multirow{2}{*}{$\begin{array}{c}\# 41 \\
2008 / \\
12 / 28\end{array}$} & $\begin{array}{l}\text { Ill nanny inspires push for } \\
\text { reform }\end{array}$ & \multirow[t]{2}{*}{$\mathrm{X}$} & \multirow[t]{2}{*}{$\mathrm{X}$} & & & \multirow[t]{2}{*}{$\mathrm{X}$} & \multirow{2}{*}{$\begin{array}{l}\text { - story of Juana Tejada } \\
\text { - 'a diminutive and soft-spoken Filipina } \\
\text { caregiver' } \\
\text { - a symbol for changes to the rights of } \\
\text { the often voiceless, faceless live-in } \\
\text { caregivers toiling at low wages for } \\
\text { looking after Canada's young and old } \\
\text { - live-in caregivers have to live without } \\
\text { OHIP when they are on "implied } \\
\text { status" } \\
\text { - 'I worked hard and faithfully for my } \\
\text { permanent residency... I want to move } \\
\text { on with my life, have kids and start a } \\
\text { family' }\end{array}$} \\
\hline & Nicholas Keung & & & & & & \\
\hline \multirow{2}{*}{$\begin{array}{c}\# 42 \\
2009 / \\
01 / 03\end{array}$} & $\begin{array}{l}\text { High cost of looking after } \\
\text { others' kids }\end{array}$ & & \multirow[t]{2}{*}{$\mathrm{X}$} & \multirow[t]{2}{*}{$\mathrm{X}$} & \multirow[t]{2}{*}{$\mathrm{X}$} & \multirow[t]{2}{*}{$\mathrm{X}$} & \multirow[b]{2}{*}{$\begin{array}{l}\text { - } \text { story of Vicky Policarpio, Judy } \\
\text { Gonzalez, Maria Castro } \\
\text { - all university educated, heartbreak of } \\
\text { years of separation (average = 8 years) } \\
\text { and reunion: loneliness, estrangement } \\
\text { - Filipino teenagers = one of highest } \\
\text { school drop out rates in Toronto } \\
\text { - LCP as a 'a transaction between rich } \\
\text { and poor countries' } \\
\text { - guilt and anger; 'Whenever I would } \\
\text { hold any child, I would think I was } \\
\text { holding my own child. I looked after } \\
\text { them as if they were my own because } \\
\text { my own were so far away' } \\
\text { - 'Their mothers are different, too: } \\
\text { independent breadwinners who long } \\
\text { ago abandoned their traditional } \\
\text { submissive roles' } \\
\text { - eliminate live-in clause and let } \\
\text { caregivers choose employers: 'We } \\
\text { need to let this community know these } \\
\text { women can be good citizens of Canada' }\end{array}$} \\
\hline & Lesley Ciarula Taylor & & & & & & \\
\hline \multirow{2}{*}{$\begin{array}{c}\# 43 \\
2009 / \\
02 / 28\end{array}$} & $\begin{array}{l}\text { Filipinos debate their } \\
\text { identity, how they fit in }\end{array}$ & \multirow[t]{2}{*}{$\mathrm{X}$} & \multirow[t]{2}{*}{$X$} & & & \multirow[t]{2}{*}{$\mathrm{X}$} & \multirow{2}{*}{$\begin{array}{l}\text { - Luz del Rosario: I came here so my } \\
\text { children could have a better life } \\
\text { - 'Why don't you become that politician } \\
\text { who creates that bill that changes the } \\
\text { law to rescue live-in caregivers?' }\end{array}$} \\
\hline & Lesley Ciarula Taylor & & & & & & \\
\hline
\end{tabular}




\begin{tabular}{|c|c|c|c|c|c|c|c|}
\hline $\begin{array}{c}\# \\
\text { DATE }\end{array}$ & ARTICLE + AUTHOR & 竞: & 疍 & $\stackrel{\leq}{\stackrel{S}{\Xi}}$ & 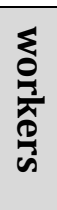 & 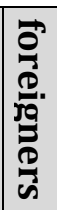 & NOTES \\
\hline \multirow{2}{*}{$\begin{array}{l}\# 44 \\
2009 / \\
02 / 28\end{array}$} & $\begin{array}{l}\text { Why it's bad to cheat the } \\
\text { nanny }\end{array}$ & & & & $X$ & X & \multirow{2}{*}{$\begin{array}{l}\text { - 'it is imperative that Canadians - who } \\
\text { have escaped their own Nannygate } \\
\text { scandal so far - pay the proper taxes } \\
\text { for employing a nanny' } \\
\text { - 'When you employ a nanny, you are an } \\
\text { employer' } \\
\text { - complicated: 'You are telling your } \\
\text { children something important' } \\
\text { - 'The biggest mistake employers make, } \\
\text { Rich says, is thinking the nanny can } \\
\text { just fit into a Canadian household } \\
\text { without being acclimatized' } \\
\text { - 'Remember these people are going to } \\
\text { be Canadian citizens' }\end{array}$} \\
\hline & Trish Crawford & & & & & & \\
\hline \multirow{2}{*}{$\begin{array}{l}\# 45 \\
2009 / \\
03 / 08\end{array}$} & $\begin{array}{l}\text { Nanny back in hospital as } \\
\text { her cancer worsens }\end{array}$ & \multirow[t]{2}{*}{$\mathrm{X}$} & \multirow[t]{2}{*}{$\mathrm{X}$} & \multirow[t]{2}{*}{$\mathrm{X}$} & \multirow[t]{2}{*}{$\mathrm{X}$} & \multirow[t]{2}{*}{$\mathrm{X}$} & \multirow{2}{*}{$\begin{array}{l}\text { - story of Juana Tejada } \\
\text { - 'dying wish' to visit family in } \\
\text { Philippines (and see LCP changed - } \\
\text { recommendations for } 2^{\text {nd }} \text { health exam) } \\
\text { - appeal on humanitarian groups } \\
\text { - 'I worked hard and faithfully... will } \\
\text { work harder when I'm cancer-free' }\end{array}$} \\
\hline & Nicholas Keung & & & & & & \\
\hline \multirow{2}{*}{$\begin{array}{l}\# 46 \\
2009 / \\
03 / 11\end{array}$} & $\begin{array}{l}\text { Juana Tejada, 39: Nanny } \\
\text { inspired reforms for } \\
\text { caregivers }\end{array}$ & \multirow[t]{2}{*}{$\mathrm{X}$} & \multirow[t]{2}{*}{$\mathrm{X}$} & \multirow[t]{2}{*}{$X$} & \multirow[t]{2}{*}{ X } & \multirow[t]{2}{*}{$\mathrm{X}$} & \multirow{2}{*}{$\begin{array}{l}\text { - story of Juana Tejada (obituary) } \\
\text { - 'tiny and soft spoken... voice for } \\
\text { migrant nannies' } \\
\text { - 'she sacrificed her whole life for us' } \\
\text { - had planned to start working again to } \\
\text { sponsor her family's immigration }\end{array}$} \\
\hline & Nicholas Keung & & & & & & \\
\hline \multirow{2}{*}{$\begin{array}{l}\# 47 \\
2009 / \\
03 / 14\end{array}$} & $\begin{array}{l}\text { Nannies trapped in bogus } \\
\text { jobs }\end{array}$ & & \multirow[t]{2}{*}{$\mathrm{X}$} & \multirow[t]{2}{*}{$X$} & & \multirow[t]{2}{*}{$\mathrm{X}$} & \multirow[b]{2}{*}{$\begin{array}{l}\text { - } \text { part } 1 \text { of TO star investigation } \\
\text { - } \text { story of Joelina Maluto } \\
\text { - claims promised job with a Toronto } \\
\text { family to be non-existent when she } \\
\text { arrived from Hong Kong illegally } \\
\text { - 'a demure 44-year-old mother of 4' } \\
\text { - } \quad \text { story of mistreatment played out by } \\
\text { many in Ontario: a nanny trap } \\
\text { - CBSA officials: 'ongoing fraud [90\%] } \\
\text { and misrepresentation [human } \\
\text { trafficking]' within program; exploit } \\
\text { people's dreams to come to Canada } \\
\text { - recruiter Spivak (Rakela Care Agency): } \\
\text { ads promise "real jobs" and "real } \\
\text { employers" } \\
\text { - program leaves 'innocent victims' } \\
\text { open to exploitation; nannies unable } \\
\text { to pay placement fees from agencies } \\
\text { - Spivak: 'that's their problem, not mine' }\end{array}$} \\
\hline & $\begin{array}{l}\text { Dale Brazao and Robert } \\
\text { Cribb }\end{array}$ & & & & & & \\
\hline
\end{tabular}




\begin{tabular}{|c|c|c|c|c|c|c|c|}
\hline $\begin{array}{c}\# \\
\text { DATE }\end{array}$ & ARTICLE + AUTHOR & 竞. & 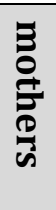 & 胥. & 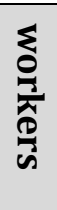 & 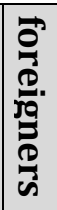 & NOTES \\
\hline \multirow{2}{*}{$\begin{array}{c}\# 48 \\
2009 / \\
03 / 15\end{array}$} & $\begin{array}{l}\text { Federal agencies fail to } \\
\text { protect migrant nannies }\end{array}$ & & & \multirow[t]{2}{*}{$\mathrm{X}$} & & \multirow[t]{2}{*}{$\mathrm{X}$} & \multirow{2}{*}{$\begin{array}{l}\text { - part } 2 \text { of TO Star investigation } \\
\text { - many foreign caregivers paying lots of } \\
\text { money to come to Canada to learn jobs } \\
\text { turn out to be fake } \\
\text { - } \text { sponsoring families under the salary } \\
\text { - employees quitting: 'feeling unwanted' }\end{array}$} \\
\hline & Robert Cribb & & & & & & \\
\hline \multirow{2}{*}{$\begin{array}{c}\# 49 \\
2009 / \\
03 / 17\end{array}$} & $\begin{array}{l}\text { Critics want crackdown as } \\
\text { nannies exploited }\end{array}$ & & & \multirow[t]{2}{*}{$\mathrm{X}$} & & \multirow[t]{2}{*}{$\mathrm{X}$} & \multirow[b]{2}{*}{ 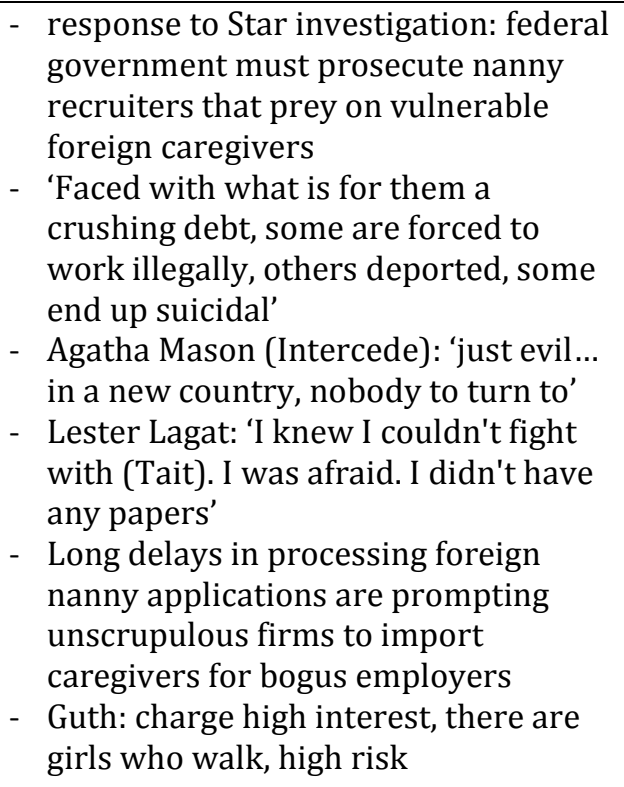 } \\
\hline & Robert Cribb & & & & & & \\
\hline \multirow{2}{*}{$\begin{array}{c}\# 50 \\
2009 / \\
03 / 18\end{array}$} & $\begin{array}{l}\text { Government ignores foreign } \\
\text { nannies' plight }\end{array}$ & & & \multirow[t]{2}{*}{$\mathrm{X}$} & \multirow[t]{2}{*}{$\mathrm{X}$} & \multirow[t]{2}{*}{$\mathrm{X}$} & \multirow{2}{*}{$\begin{array}{l}\text { - expose Ontario's "nanny trap" } \\
\text { - 'not many Canadian women want to } \\
\text { work as nannies because the pay and } \\
\text { conditions are so terrible' } \\
\text { - foreign women workers always get the } \\
\text { worst in human trafficking } \\
\text { - 'vulnerable women, isolated and } \\
\text { frightened, forced to pay illegal fees } \\
\text { - while families at home starve' } \\
\text { - government solution to daycare crisis? }\end{array}$} \\
\hline & Antonia Zerbisias & & & & & & \\
\hline \multirow{2}{*}{$\begin{array}{c}\text { \#51 } \\
\text { 2009/ } \\
03 / 18\end{array}$} & Stop the nanny abuses & & & \multirow[t]{2}{*}{$\mathrm{X}$} & \multirow[t]{2}{*}{$\mathrm{X}$} & \multirow[t]{2}{*}{$\mathrm{X}$} & \multirow{2}{*}{$\begin{array}{l}\text { - legality of taking money from nannies } \\
\text { during recruiting process in Ontario } \\
\text { (business - exploitation = hub for } \\
\text { human trafficking) } \\
\text { - 'easy prey, aspiring nannies so } \\
\text { desperate for a better life in Canada, } \\
\text { indentured servants }\end{array}$} \\
\hline & Opinion & & & & & & \\
\hline
\end{tabular}




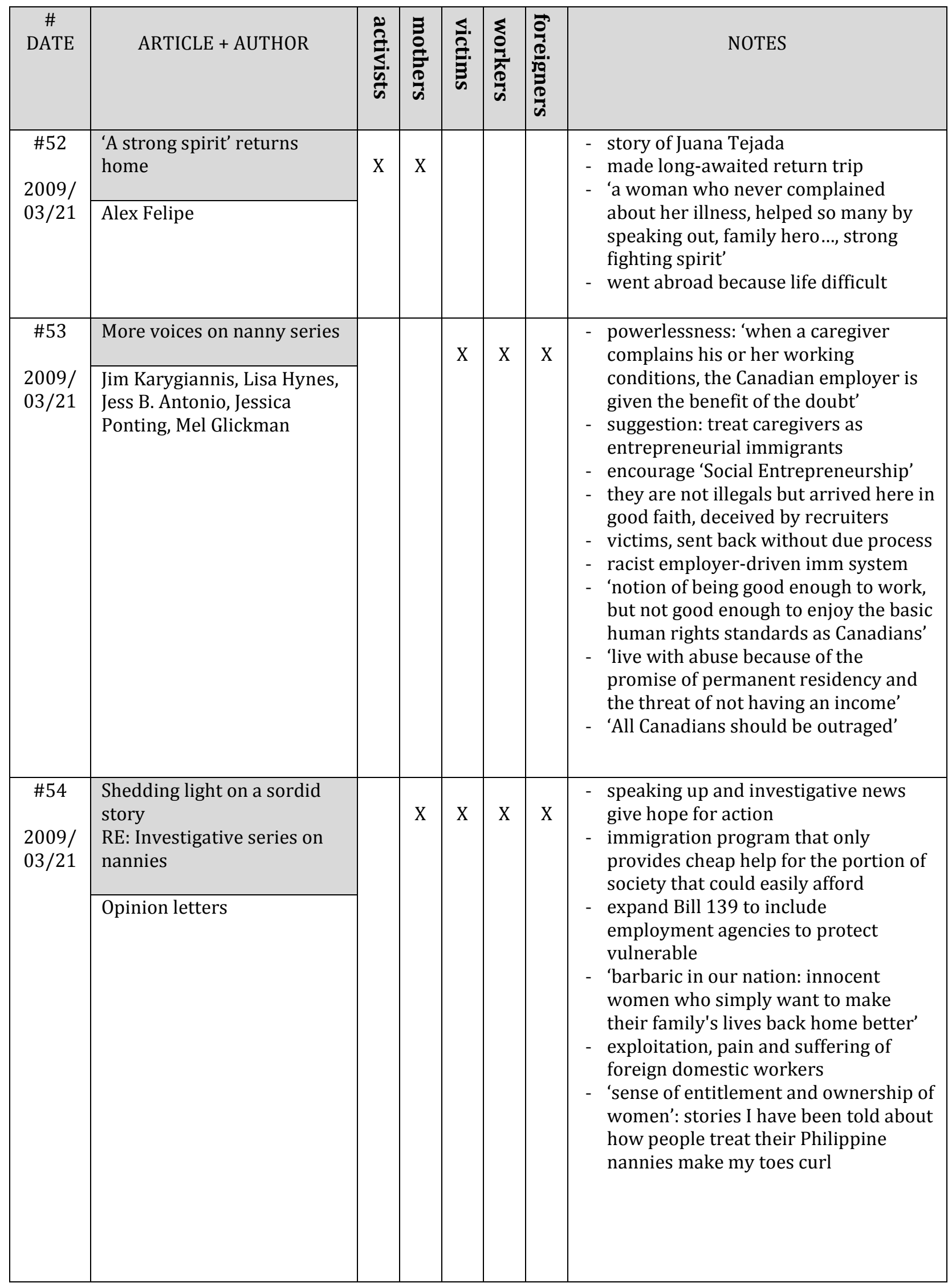




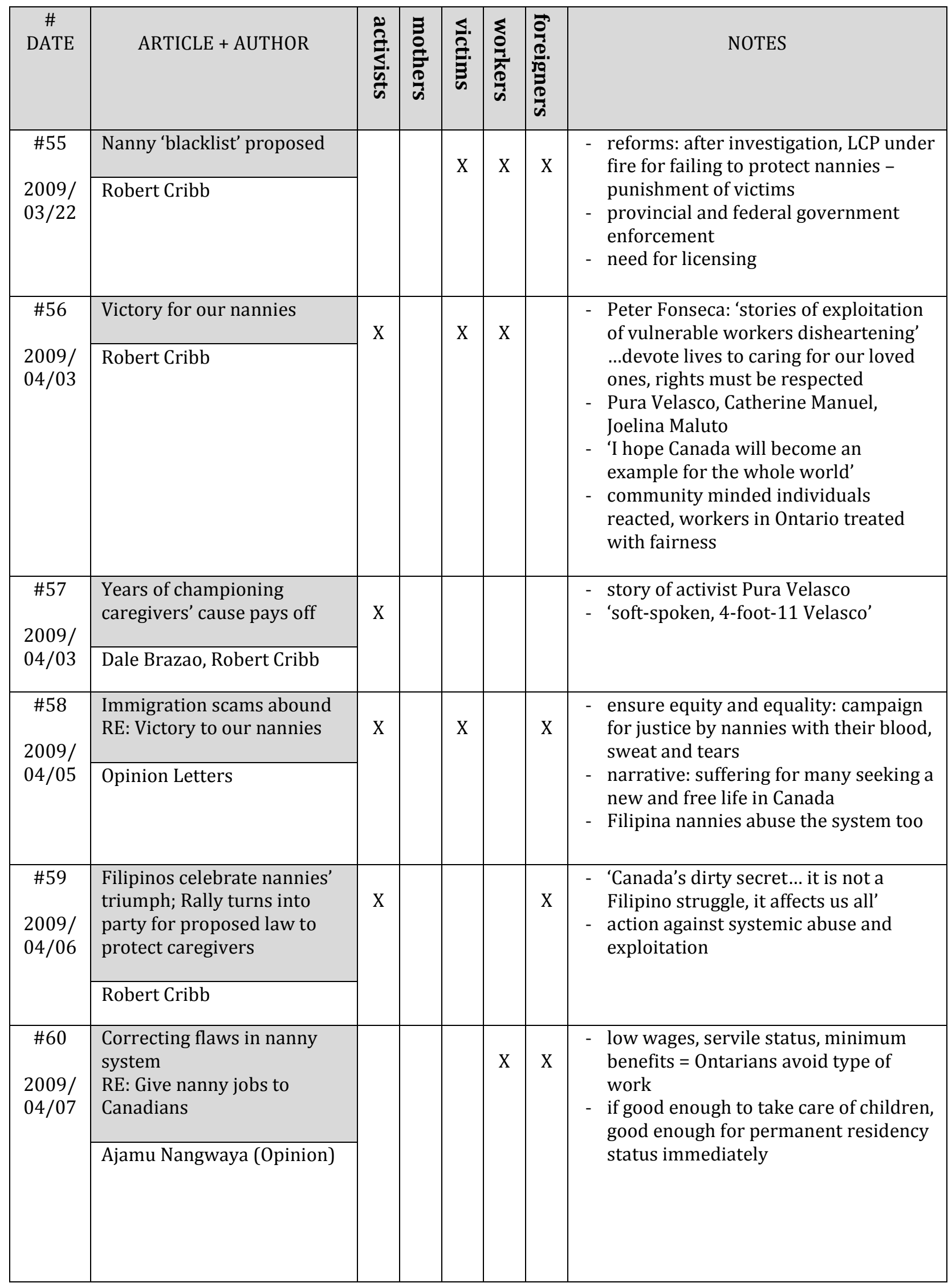




\begin{tabular}{|c|c|c|c|c|c|c|c|}
\hline $\begin{array}{c}\# \\
\text { DATE }\end{array}$ & ARTICLE + AUTHOR & 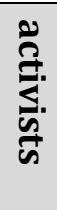 & 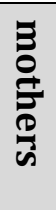 & 音: & 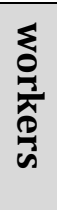 & 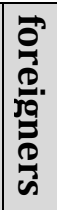 & NOTES \\
\hline $\begin{array}{l}\# 61 \\
2009 / \\
04 / 09\end{array}$ & $\begin{array}{l}\text { Job bank could end rogue } \\
\text { fees for nannies; } \\
\text { Recruitment agencies would } \\
\text { close, critics say }\end{array}$ & & & $\mathrm{X}$ & & & $\begin{array}{l}\text { - } \text { agencies charging nannies 'exorbitant } \\
\text { recruitment fees' } \\
\text { - The Star found many of the province's } \\
\text { 8,000 live-in caregivers paid agencies } \\
\text { thousands of dollars for jobs in } \\
\text { Ontario that don't exist }\end{array}$ \\
\hline $\begin{array}{l}\# 62 \\
2009 / \\
04 / 27\end{array}$ & $\begin{array}{l}\begin{array}{l}\text { Ontario's 'Nanny Hotline' } \\
\text { goes live }\end{array} \\
\text { Dale Brazao }\end{array}$ & $\mathrm{X}$ & & & & & $\begin{array}{l}\text { Foreign caregivers working in Ontario } \\
\text { who believe they've been abused by } \\
\text { labour recruiters or employers now } \\
\text { have a direct line to the provincial } \\
\text { government } \\
\text { - help protect vulnerable employees } \\
\text { under LCP }\end{array}$ \\
\hline $\begin{array}{c}\text { \#63 } \\
\text { 2009/ } \\
05 / 05\end{array}$ & $\begin{array}{l}\text { Ruby Dhalla's nanny trouble } \\
\text { Dale Brazao }\end{array}$ & & & $\mathrm{X}$ & & & $\begin{array}{l}\text { - Ruby Dhalla, Liberal MP: 'nanny trap' } \\
\text { scandal - allegations two nannies } \\
\text { hired to care for her mother were } \\
\text { illegally employed and then } \\
\text { mistreated } \\
\text { - surfaced at public meeting: LCP keeps } \\
\text { workers 'enslaved' } \\
\text { - jobs unrelated to caring for mother: } \\
\text { 'She wanted a slave, not a caregiver' } \\
\text { - brother Neil Dhalla: 'being used as a } \\
\text { dupe and pawn by people desperate to } \\
\text { remain in Canada at any cost' } \\
\text { - nannies Gordo and Tongson currently } \\
\text { working legally for families who treat } \\
\text { them well }\end{array}$ \\
\hline $\begin{array}{c}\# 64 \\
2009 / \\
05 / 06\end{array}$ & $\begin{array}{l}\text { Give nannies more time to } \\
\text { meet requirements } \\
\text { Joanna Smith }\end{array}$ & $X$ & $X$ & $X$ & $X$ & $\mathrm{X}$ & $\begin{array}{l}\text { - 'Nannies who quit their jobs because } \\
\text { they are mistreated should be given } \\
\text { more time to meet requirements to } \\
\text { become permanent residents of } \\
\text { Canada before being deported' } \\
\text { - No one should feel that they have to } \\
\text { tolerate mistreatment in the short } \\
\text { term for the long-term gain of } \\
\text { permanent residency } \\
\text { - stakes are high also for families left } \\
\text { behind waiting to reunite } \\
\text { - inspired by Juana Tejada }\end{array}$ \\
\hline
\end{tabular}




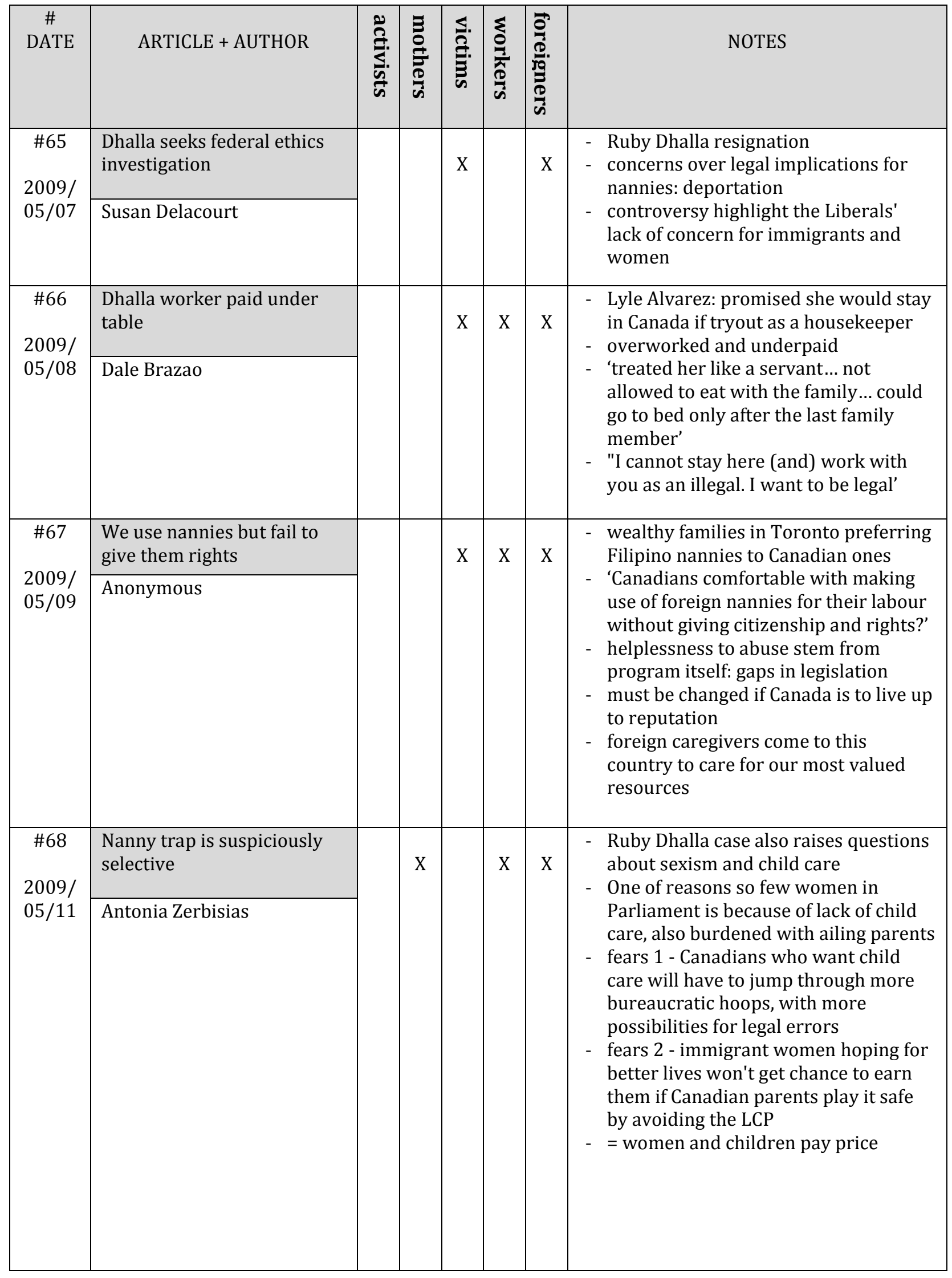




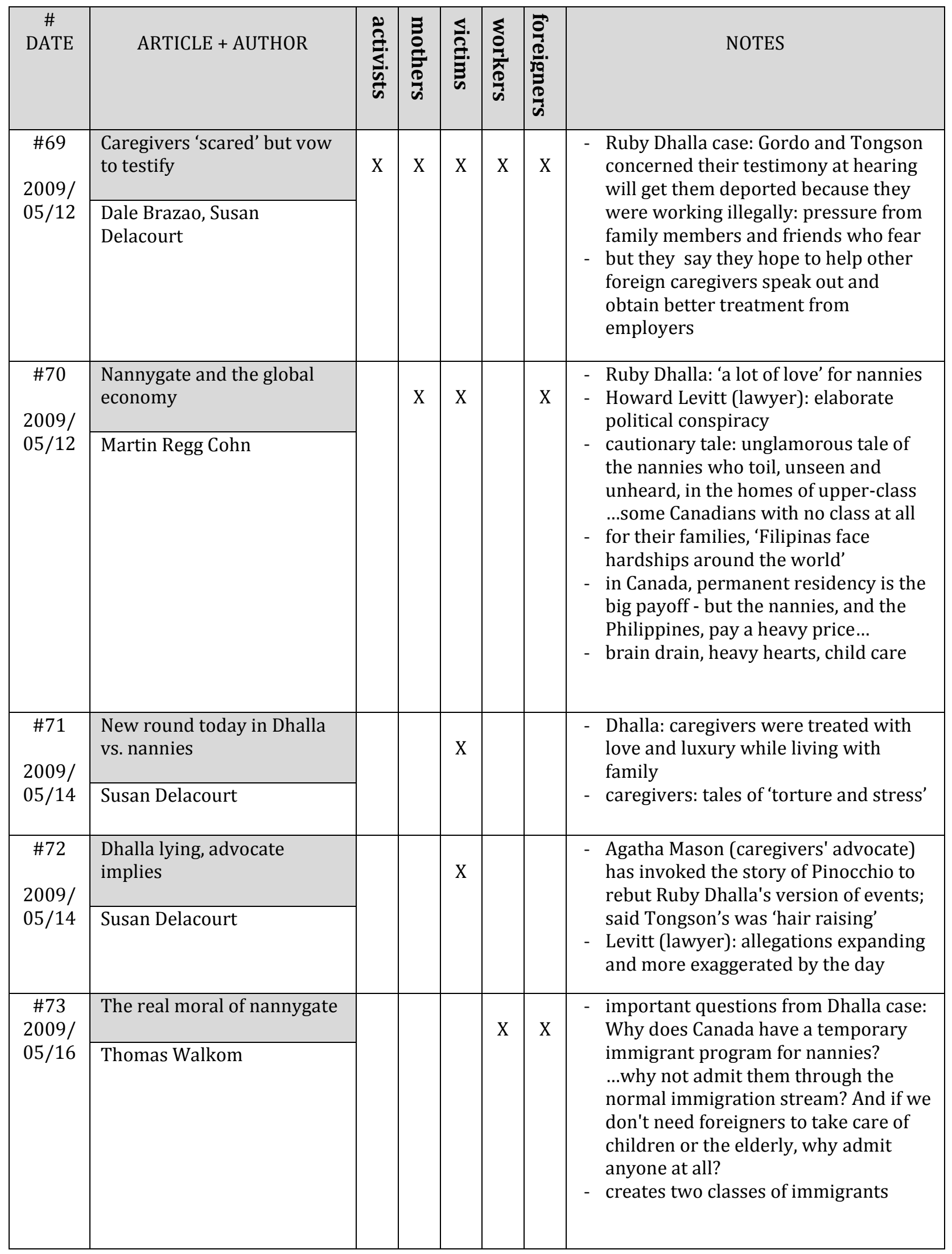




\begin{tabular}{|c|c|c|c|c|c|c|c|}
\hline $\begin{array}{c}\# \\
\text { DATE }\end{array}$ & ARTICLE + AUTHOR & 竞: & 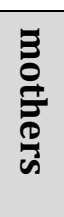 & $\stackrel{\leq}{\grave{E}}$ & 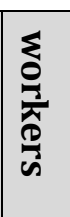 & 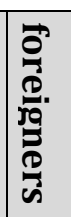 & NOTES \\
\hline $\begin{array}{c}\# 74 \\
2009 / \\
05 / 18\end{array}$ & $\begin{array}{l}\text { The exploitation of nannies } \\
\text { has a long, dreary history } \\
\text { Lorne Waldman }\end{array}$ & & & $X$ & X & $X$ & $\begin{array}{l}\text { - In the 1960s, the nannies were most } \\
\text { often illegal immigrants who worked } \\
\text { long hours for little pay cleaning our } \\
\text { houses and caring for our children } \\
\text { - } \text { illegal immigrants who are the most } \\
\text { vulnerable to abuse; percentage of } \\
\text { nannies that lack status - must be } \\
\text { encouraged to come out of shadows } \\
\text { and regularize status } \\
\text { - provide an important service to our } \\
\text { community; caring for our children so } \\
\text { we can work productively }\end{array}$ \\
\hline $\begin{array}{c}\# 75 \\
2009 / \\
05 / 29\end{array}$ & $\begin{array}{l}\begin{array}{l}\text { Caregiver denies using } \\
\text { family to get into Canada }\end{array} \\
\text { Dale Brazao }\end{array}$ & & & $X$ & & & $\begin{array}{l}\text { - story of Magdalene Gordo (accuse } \\
\text { Ruby Dhalla): former employer George } \\
\text { Roswell now saying she used them } \\
\text { - original story in Globe and Mail } \\
\text { - Gordo: not comfortable in their home } \\
\text { and feeling ill; 'treated' to Christmas } \\
\text { gifts and Niagara trip } \\
\text { - agency advised her to leave if } \\
\text { unhappy, Roswells made her leave } \\
\text { immediately }\end{array}$ \\
\hline $\begin{array}{c}776 \\
2009 / \\
05 / 30\end{array}$ & $\begin{array}{l}\text { Ex-boss denies nanny slept } \\
\text { on floor }\end{array}$ & & & $X$ & & & $\begin{array}{l}\text { - } \text { story of Magdalene Gordo } \\
\text { - Roswell claim she was a guest in their } \\
\text { home for first two weeks } \\
\text { - 'out of the kindness of our hearts, we } \\
\text { provided her with gifts' } \\
\text { - different versions of story }\end{array}$ \\
\hline $\begin{array}{c}\# 77 \\
2009 / \\
06 / 06\end{array}$ & $\begin{array}{l}\text { Report calls for 'nannygate' } \\
\text { probe; Urges agencies to } \\
\text { look into allegations by } \\
\text { Dhalla's ex-caregivers } \\
\text { Dale Brazao }\end{array}$ & & & $X$ & & & $\begin{array}{l}\text { - Ruby Dhalla case } \\
\text { - Gordo: 'I am confident the truth will } \\
\text { prevail, and we have told the truth' } \\
\text { - theme of truth/version of } \\
\text { events/credibility of stories }\end{array}$ \\
\hline $\begin{array}{c}\# 78 \\
2009 / \\
06 / 11\end{array}$ & $\begin{array}{l}\text { Dhalla case not closed } \\
\text { Anonymous }\end{array}$ & & & $X$ & & & $\begin{array}{l}\text { - attack on credibility and excuses of } \\
\text { Ruby Dhalla } \\
\text { - need for more comprehensive } \\
\text { investigation and recommendations }\end{array}$ \\
\hline
\end{tabular}




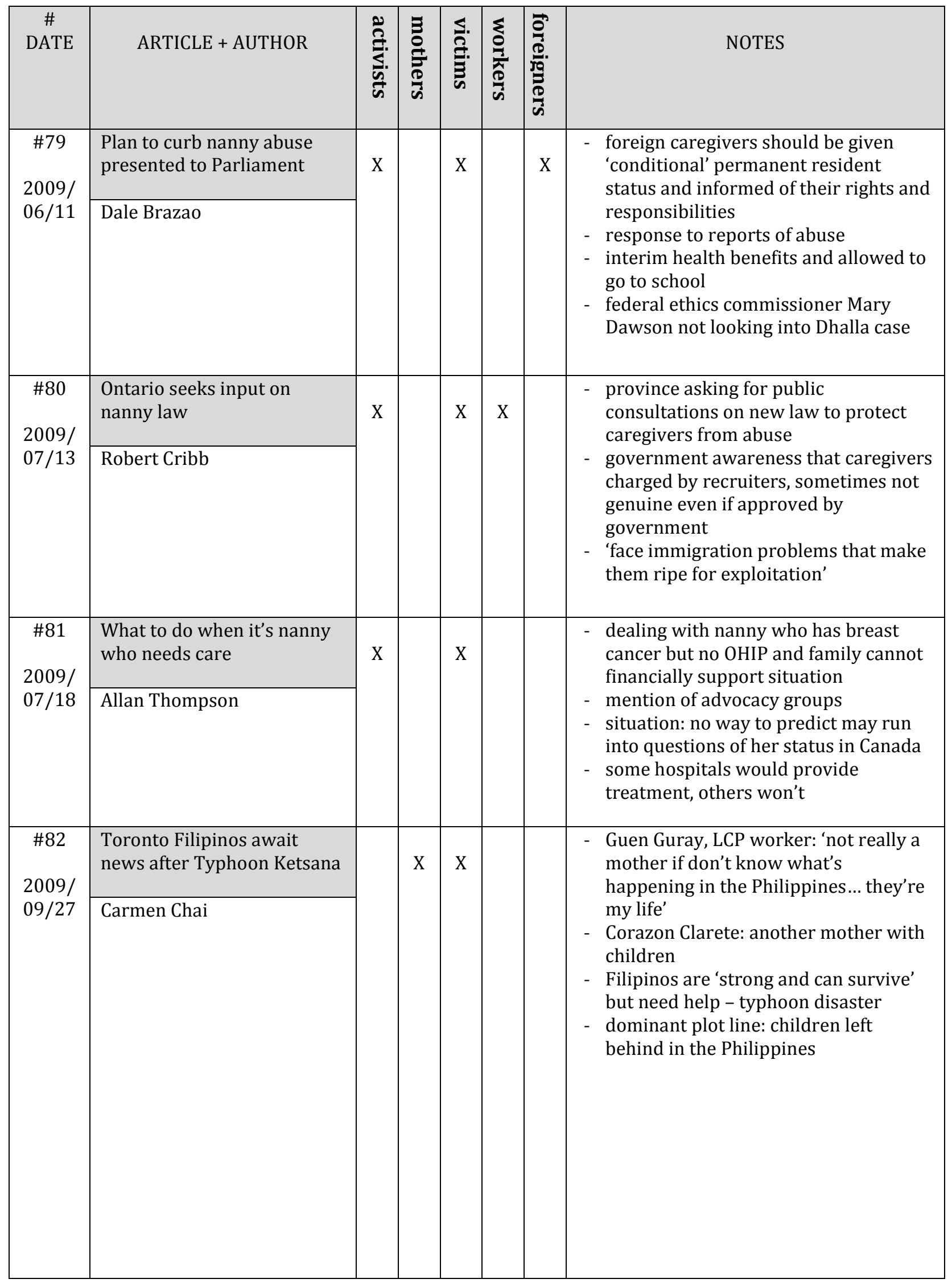




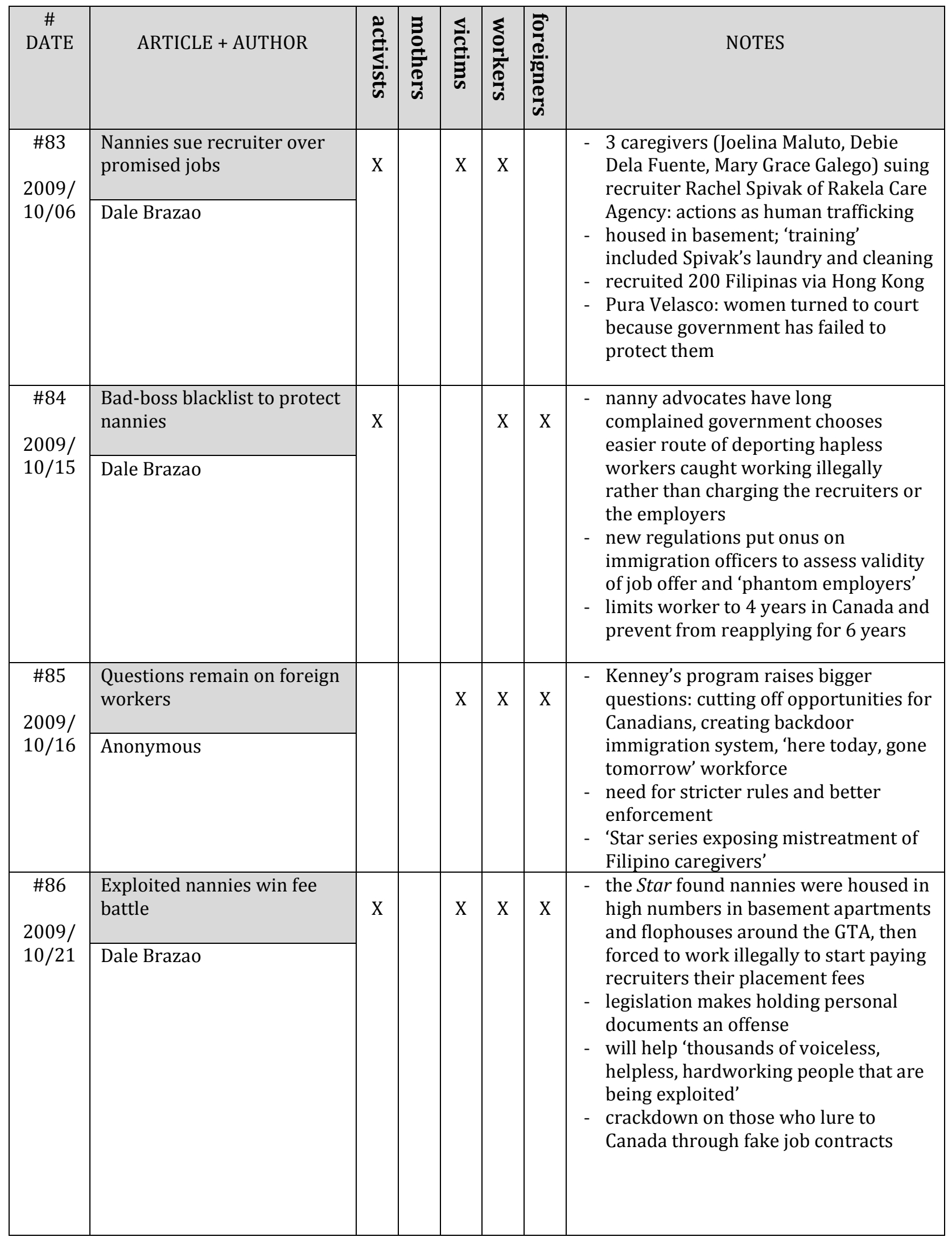




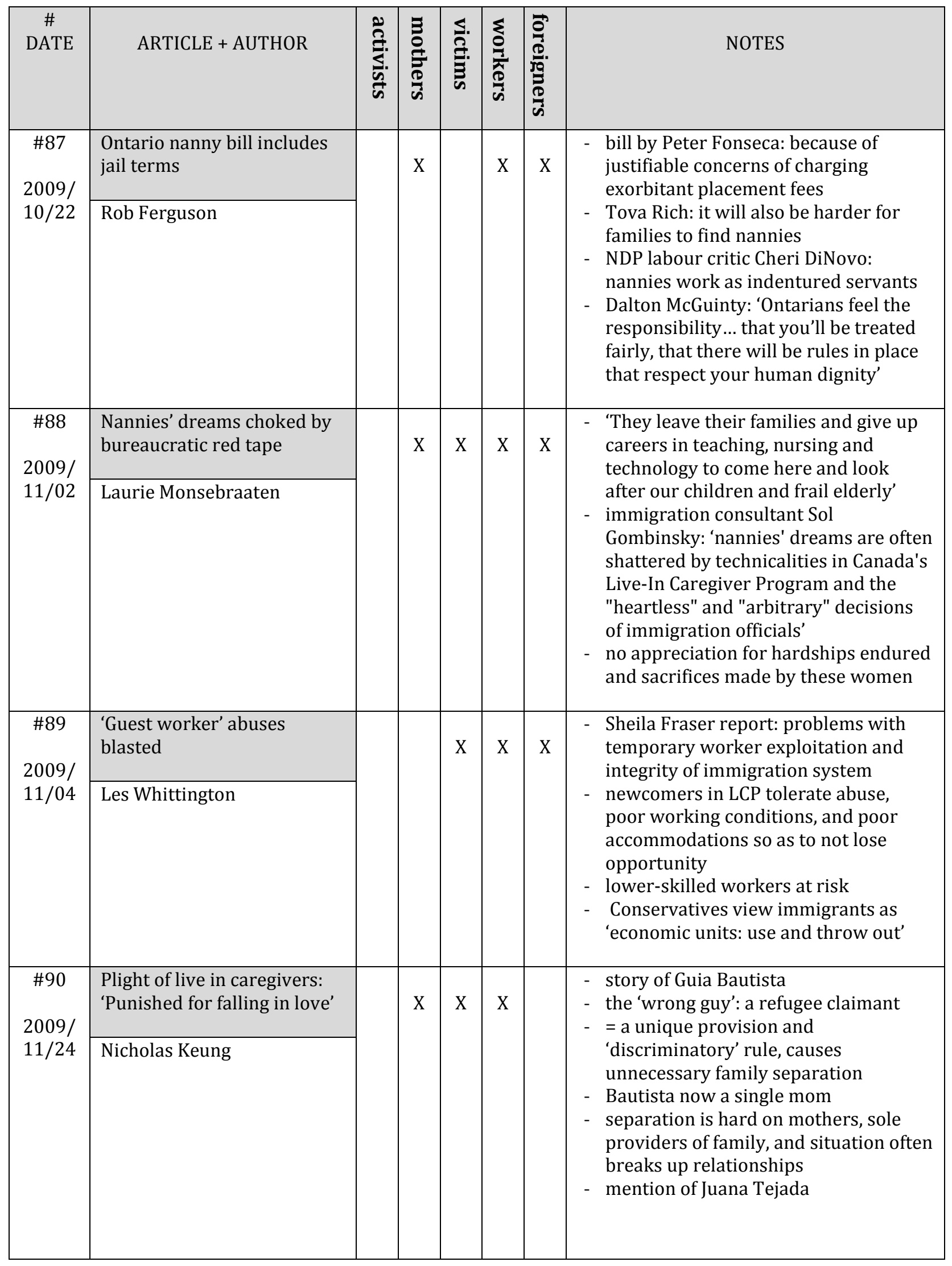




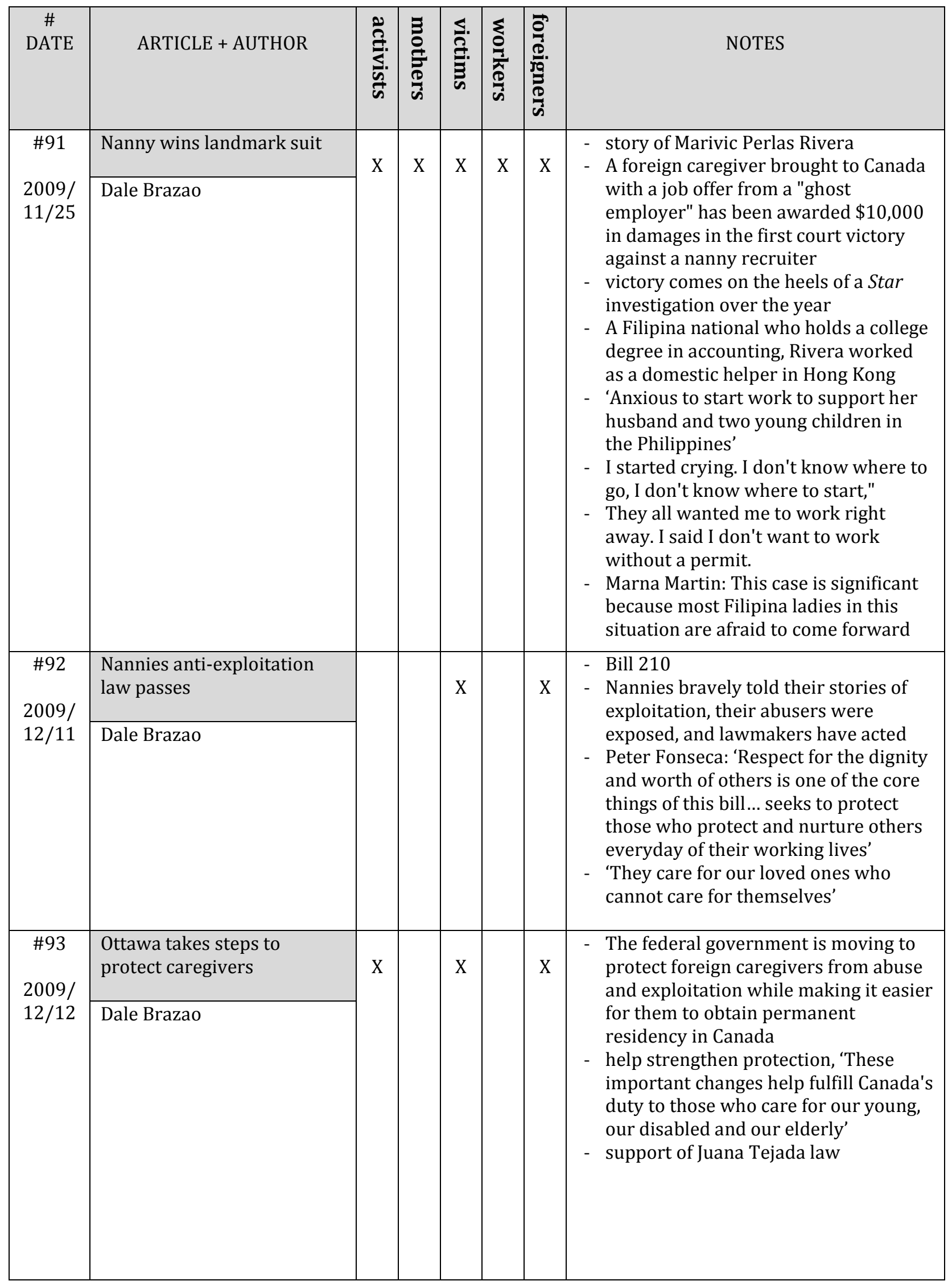




\begin{tabular}{|c|c|c|c|c|c|c|c|}
\hline $\begin{array}{c}\# \\
\text { DATE }\end{array}$ & ARTICLE + AUTHOR & 㫄. & 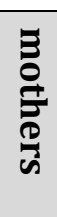 & 交. & 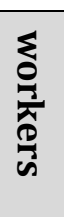 & 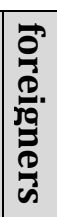 & NOTES \\
\hline \multirow{2}{*}{$\begin{array}{c}\# 94 \\
2009 / \\
12 / 13\end{array}$} & New nanny laws 'a start' & \multirow{2}{*}{$\mathrm{X}$} & & \multirow{2}{*}{$\mathrm{X}$} & & \multirow{2}{*}{$\mathrm{X}$} & \multirow{2}{*}{$\begin{array}{l}\text { - Velasco commended the government } \\
\text { for the changes, but said the } \\
\text { Temporary Foreign Workers' Program } \\
\text { governing nannies is still "a mess" that } \\
\text { exploits workers } \\
\text { - Faye Arellano: made the noise thanks } \\
\text { to Star and advocates } \\
\text { - Kenney RE: permanent residency = } \\
\text { mend the program, not end it }\end{array}$} \\
\hline & Brendan Kennedy & & & & & & \\
\hline \multirow{2}{*}{$\begin{array}{c}\text { \#95 } \\
\text { 2009/ } \\
12 / 19\end{array}$} & $\begin{array}{l}\text { Good package of changes for } \\
\text { live-in caregivers }\end{array}$ & & & & & \multirow[t]{2}{*}{$\mathrm{X}$} & \multirow{2}{*}{$\begin{array}{l}\text { - permanent residence status } \\
\text { - A key factor in these immigration } \\
\text { medical exams is determining whether } \\
\text { an applicant has a medical condition } \\
\text { that would pose excessive burden on } \\
\text { the Canadian healthcare system }\end{array}$} \\
\hline & Allan Thompson & & & & & & \\
\hline \multirow[t]{2}{*}{$\begin{array}{c}\text { \#96 } \\
\text { 2010/ } \\
01 / 16\end{array}$} & $\begin{array}{l}\text { Consumers in the wild; Mass } \\
\text { marketers tap } \\
\text { anthropologists to learn } \\
\text { what's really going on at } \\
\text { home }\end{array}$ & & & & & \multirow[t]{2}{*}{$\mathrm{X}$} & \multirow[t]{2}{*}{$\begin{array}{l}\text { part of Kraft project: } 1 \text { of } 12 \text { families } \\
\text { that represent the 'new consumer': a } \\
\text { Filipino nanny raising her own } \\
\text { children and an employer's = diversity, } \\
\text { appealing to wide range of consumers }\end{array}$} \\
\hline & Dana Flavelle & & & & & & \\
\hline \multirow{2}{*}{$\begin{array}{c}\# 97 \\
2010 / \\
02 / 26\end{array}$} & $\begin{array}{l}\text { Big on heart, low on } \\
\text { everything else }\end{array}$ & & \multirow[t]{2}{*}{$\mathrm{X}$} & \multirow[t]{2}{*}{$\mathrm{X}$} & & \multirow[t]{2}{*}{$\mathrm{X}$} & \multirow[b]{2}{*}{$\begin{array}{l}\text { - } \text { review of play Future Folk } \\
\text { - Three cast members (Catherine } \\
\text { Hernandez, Karen Ancheta and Aura } \\
\text { Carcueva) play women who have come } \\
\text { from the Philippines under the Live-in } \\
\text { Caregiver Program, which, while } \\
\text { dangling the prospect of freedom in } \\
\text { front of some women in desperate } \\
\text { situations, usually provides } \\
\text { Torontonians with very affordable and } \\
\text { compliant nannies } \\
\text { - only thing you really learn about these } \\
\text { women is that they miss their families } \\
\text { - also have to ask if all Filipina nannies } \\
\text { are so saintly, all their employers are } \\
\text { so heartless and lives are so empty } \\
\text { - also include Juana Tejada story }\end{array}$} \\
\hline & Richard Ouzounian & & & & & & \\
\hline
\end{tabular}




\begin{tabular}{|c|c|c|c|c|c|c|c|}
\hline $\begin{array}{c}\# \\
\text { DATE }\end{array}$ & ARTICLE + AUTHOR & 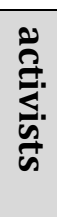 & 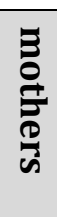 & 充: & $\frac{\sum}{\frac{1}{2}}$ & 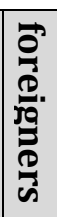 & NOTES \\
\hline \multirow{2}{*}{$\begin{array}{l}\# 98 \\
2010 / \\
06 / 06\end{array}$} & $\begin{array}{l}\text { Loophole in new law leaves } \\
\text { sick nannies at risk }\end{array}$ & & \multirow[t]{2}{*}{$\mathrm{X}$} & & & \multirow[t]{2}{*}{$\mathrm{X}$} & \multirow[b]{2}{*}{$\begin{array}{l}\text { - story of Marcia Bandales } \\
\text { - who in } 2004 \text { left behind her husband } \\
\text { and four children to work as a nanny } \\
\text { in Toronto, hoping to give family a } \\
\text { better future = but her time running } \\
\text { out } \\
\text { - despite new laws, can still be rejected } \\
\text { permanent residency on medical } \\
\text { grounds: because of breast cancer } \\
\text { diagnosis } \\
\text { = immigration officers still have } \\
\text { discretion: would “cause extensive } \\
\text { demand" on social services } \\
\text { - Toronto immigration lawyer Rafael } \\
\text { Fabregas for Juana Tejada: 'nothing } \\
\text { has changed' } \\
\text { - 'My goal is to stay in Canada and have } \\
\text { my family beside me till I die. I hope } \\
\text { they will grant me my wish' }\end{array}$} \\
\hline & Nicholas Keung & & & & & & \\
\hline \multirow[t]{2}{*}{$\begin{array}{l}\# 99 \\
2010 / \\
06 / 09\end{array}$} & $\begin{array}{l}\text { Foreign workers at bottom } \\
\text { end of payscale: Most earn } \\
\text { 'substantially' less than } \\
\text { Canadians in jobs such as } \\
\text { live-in caregivers, } \\
\text { housekeepers }\end{array}$ & & & & & \multirow[t]{2}{*}{$\mathrm{X}$} & \multirow[t]{2}{*}{$\begin{array}{l}\text { - many non-permanent members of a } \\
\text { visible minority group: biggest cluster } \\
\text { (almost } 14 \% \text { = Filipino) }\end{array}$} \\
\hline & Nicholas Keung & & & & & & \\
\hline \multirow[t]{2}{*}{$\begin{array}{l}100 \\
2010 / \\
06 / 14\end{array}$} & $\begin{array}{l}\text { Newcomers who make } \\
\text { Canada better: Twelve from } \\
\text { GTA among } 25 \text { immigrants } \\
\text { honoured for their } \\
\text { achievements here }\end{array}$ & & & & & \multirow[t]{2}{*}{$\mathrm{X}$} & \multirow[t]{2}{*}{$\begin{array}{l}\text { - Rafael Fabregas, immigration lawyer } \\
\text { - 'a step in improving profile of Filipino } \\
\text { Canadian community' } \\
\text { - 'There is nothing to be ashamed of in } \\
\text { being a live-in caregiver... I encourage } \\
\text { them to dream and aim high' }\end{array}$} \\
\hline & Nicholas Keung & & & & & & \\
\hline \multirow{2}{*}{$\begin{array}{l}\# 101 \\
2010 / \\
06 / 29\end{array}$} & $\begin{array}{l}\text { Ailing caregiver wins } \\
\text { reprieve on residency }\end{array}$ & & & \multirow[t]{2}{*}{$\mathrm{X}$} & & & \multirow[t]{2}{*}{$\begin{array}{l}\text { - story of Marcia Piamonte Bandales } \\
\text { - granted 'an exemption from being } \\
\text { medically inadmissible' }\end{array}$} \\
\hline & Anonymous & & & & & & \\
\hline
\end{tabular}




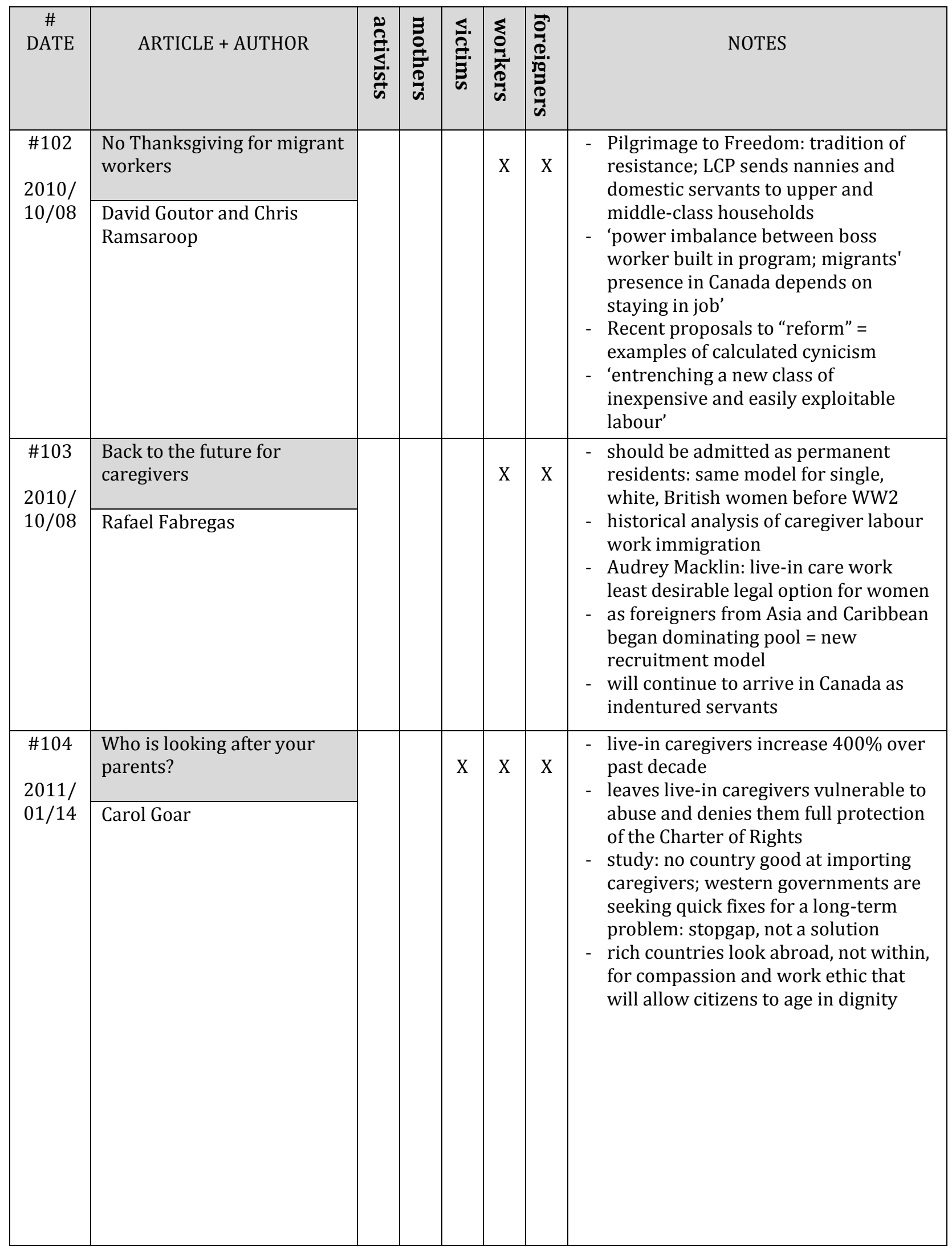




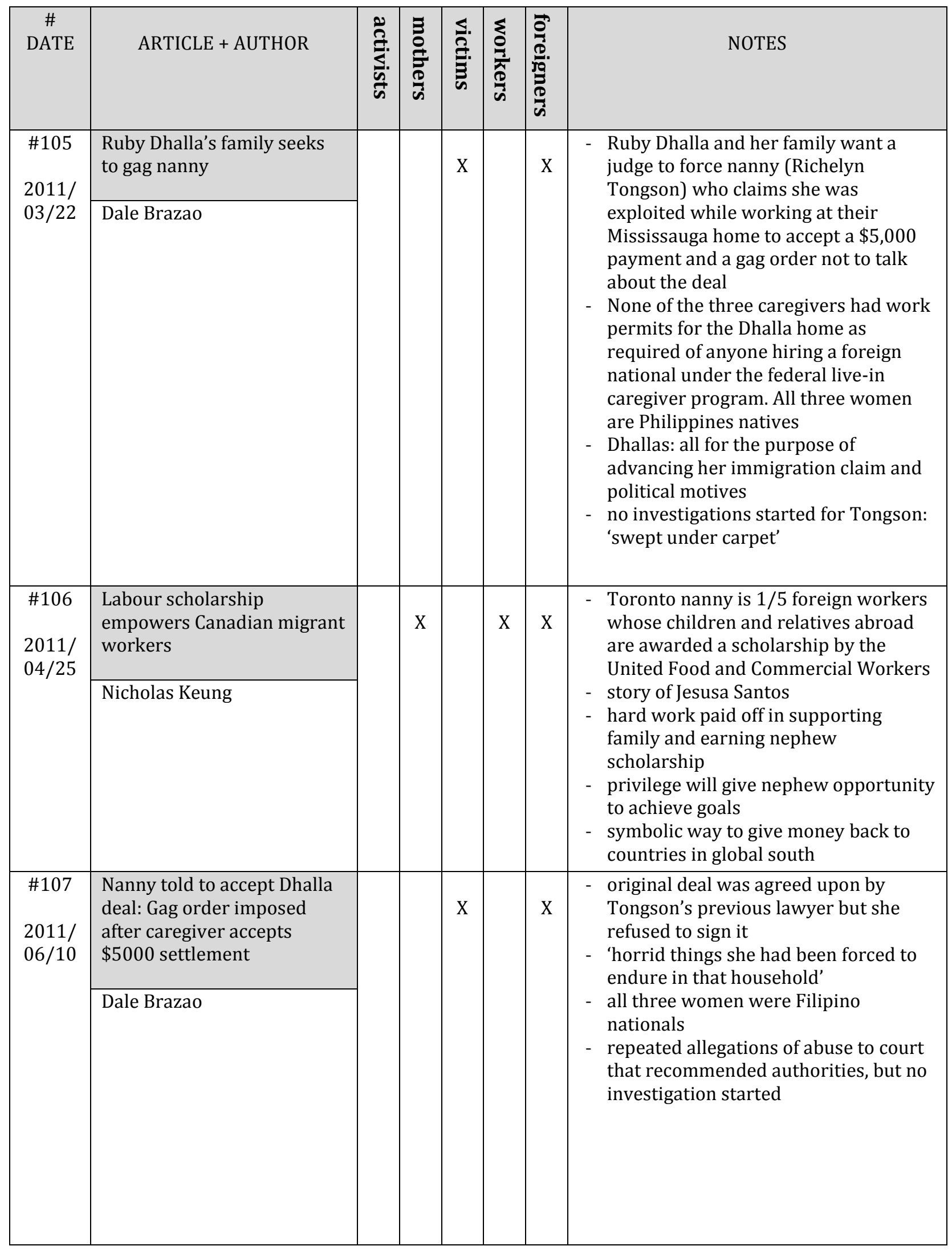




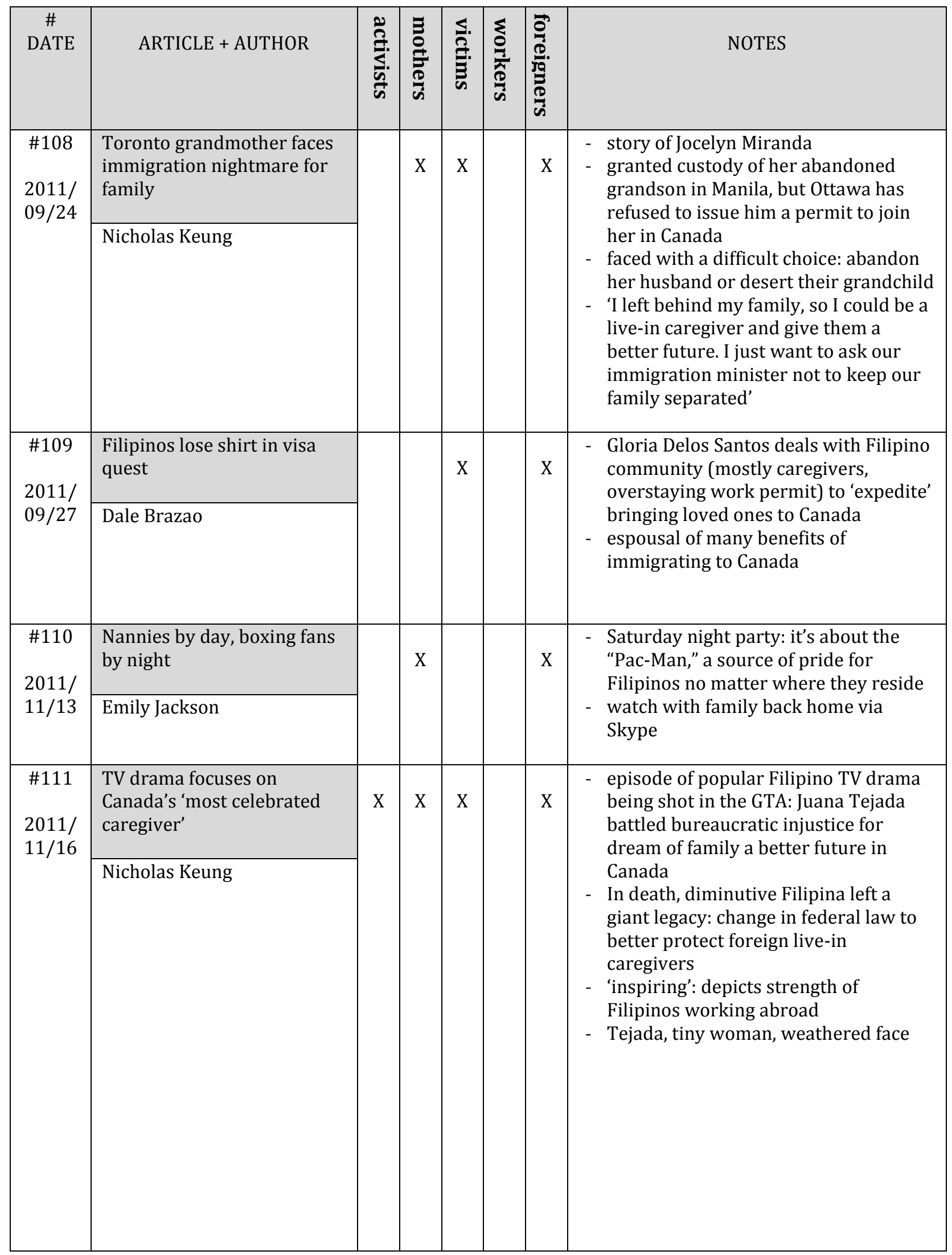




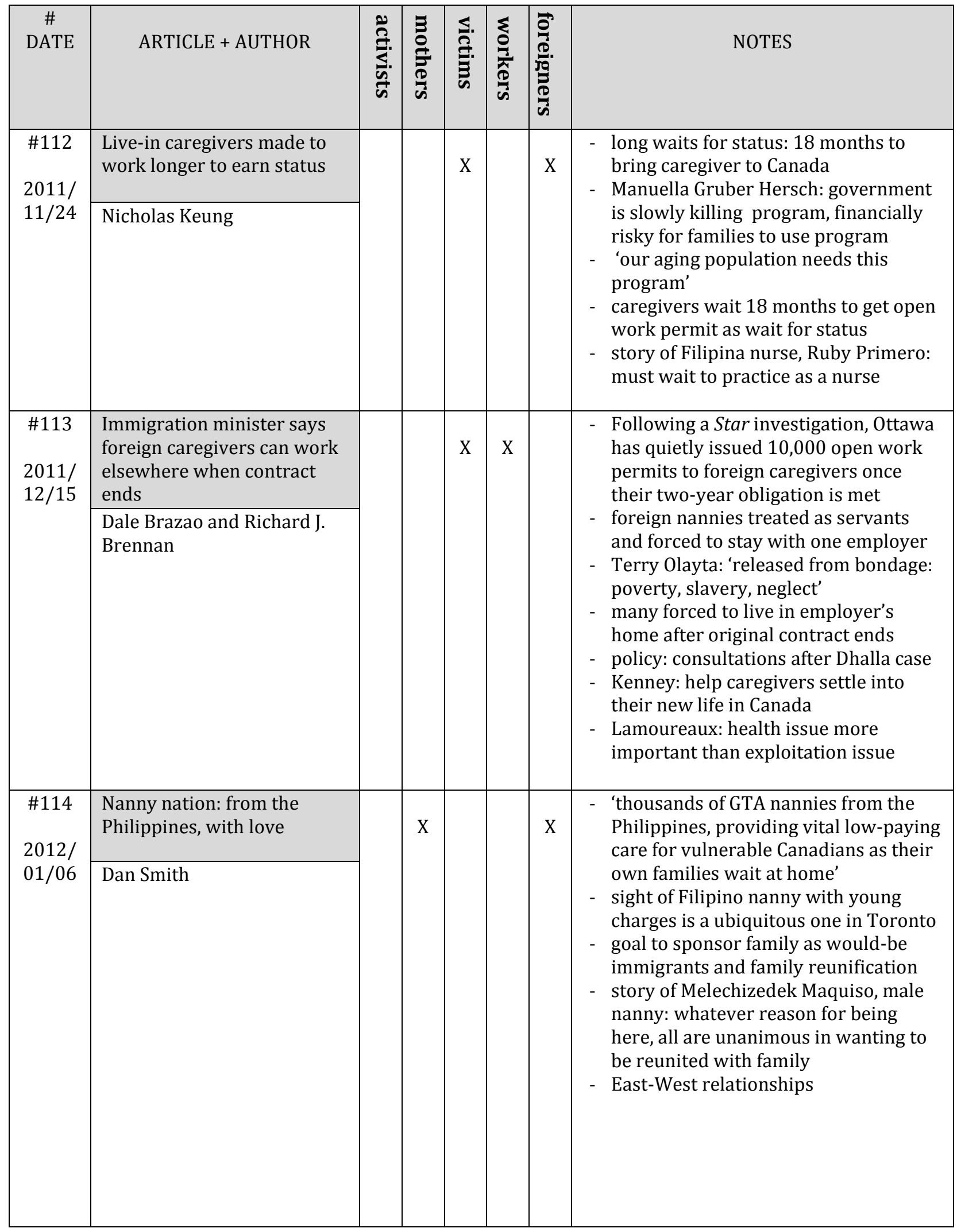




\begin{tabular}{|c|c|c|c|c|c|c|c|}
\hline $\begin{array}{c}\# \\
\text { DATE }\end{array}$ & ARTICLE + AUTHOR & ฏ. & 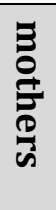 & $\stackrel{\leq}{\stackrel{S}{\Xi}}$ & 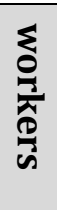 & 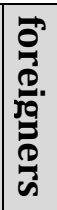 & NOTES \\
\hline \multirow{2}{*}{$\begin{array}{l}115 \\
2012 / \\
02 / 13\end{array}$} & $\begin{array}{l}\text { Shortage of live-in } \\
\text { caregivers leads to 'nanny } \\
\text { poaching' }\end{array}$ & & & & \multirow[t]{2}{*}{$\mathrm{X}$} & $\mathrm{X}$ & \multirow{2}{*}{$\begin{array}{l}\text { - shortage of live-in caregivers since } \\
\text { December: \# of live-in caregivers } \\
\text { plummeted } 40 \% \text { since peak } \\
\text { - agency: nannies moving out onto } \\
\text { professional fields, clients scrambling } \\
\text { - Ottawa's new legislation make it costly } \\
\text { for families to hire a nanny } \\
\text { - Jodi Kaplan: she and her nanny have } \\
\text { been approached by strangers } \\
\text { - 'safeguard Canadian families' } \\
\text { interests' } \\
\text { - caregivers receiving open work } \\
\text { permits have already lived up to } \\
\text { obligations }\end{array}$} \\
\hline & Nicholas Keung & & & & & & \\
\hline \multirow{2}{*}{$\begin{array}{l}\# 116 \\
2012 / \\
05 / 21\end{array}$} & $\begin{array}{l}\text { Nannies waiting longer for } \\
\text { open work permits in }\end{array}$ & & $X$ & & & $\mathrm{X}$ & \multirow{2}{*}{$\begin{array}{l}\text { - without it, must continue working as } \\
\text { live-in caregiver } \\
\text { - story of Catalina Ferano } \\
\text { - 'longed for the day she would be free } \\
\text { to do what she wants in Canada' } \\
\text { - Kenney: 'program a revolving door' } \\
\text { - difficult for caregivers to plan lives } \\
\text { and families to coordinate childcare } \\
\text { needs without consistency } \\
\text { - Ana Marie Sanchez: 'I just want to be } \\
\text { with my son and my husband' }\end{array}$} \\
\hline & Nicholas Keung & & & & & & \\
\hline \multirow{2}{*}{$\begin{array}{l}\# 117 \\
2012 / \\
05 / 21\end{array}$} & $\begin{array}{l}\text { When a migrant worker dies } \\
\text { suddenly, a community } \\
\text { takes charge }\end{array}$ & $X$ & & & & $\mathrm{X}$ & \multirow{2}{*}{$\begin{array}{l}\text { - } \text { story of Girlie Gioquino } \\
\text { - give proper memorial and repatriate } \\
\text { body to family in Philippines } \\
\text { - } \text { like many migrant workers: has no } \\
\text { family in Canada to cover funeral } \\
\text { - reach out to Filipino diaspora groups } \\
\text { - Philippine/Canadian government has } \\
\text { a role to play }\end{array}$} \\
\hline & Nicholas Keung & & & & & & \\
\hline \multirow{2}{*}{$\begin{array}{l}\# 118 \\
2013 / \\
01 / 14\end{array}$} & $\begin{array}{l}\text { Domestic workers toil in } \\
\text { penury and danger }\end{array}$ & & & & $X$ & $\mathrm{X}$ & \multirow{2}{*}{$\begin{array}{l}\text { - ILO raise red flag about LCP: means } \\
\text { they're available around the clock, } \\
\text { regardless of Canadian law; also } \\
\text { limited command of English or French } \\
\text { and little knowledge of Canadian law } \\
\text { - domestic workers are an indispensible } \\
\text { part of social fabric } \\
\text { - Canada could show leadership in } \\
\text { ratifying treaty } \\
\text { - 'We have nothing to lose. The world's } \\
\text { poorest, most powerless workers have } \\
\text { so much to gain' }\end{array}$} \\
\hline & Carol Goar & & & & & & \\
\hline
\end{tabular}




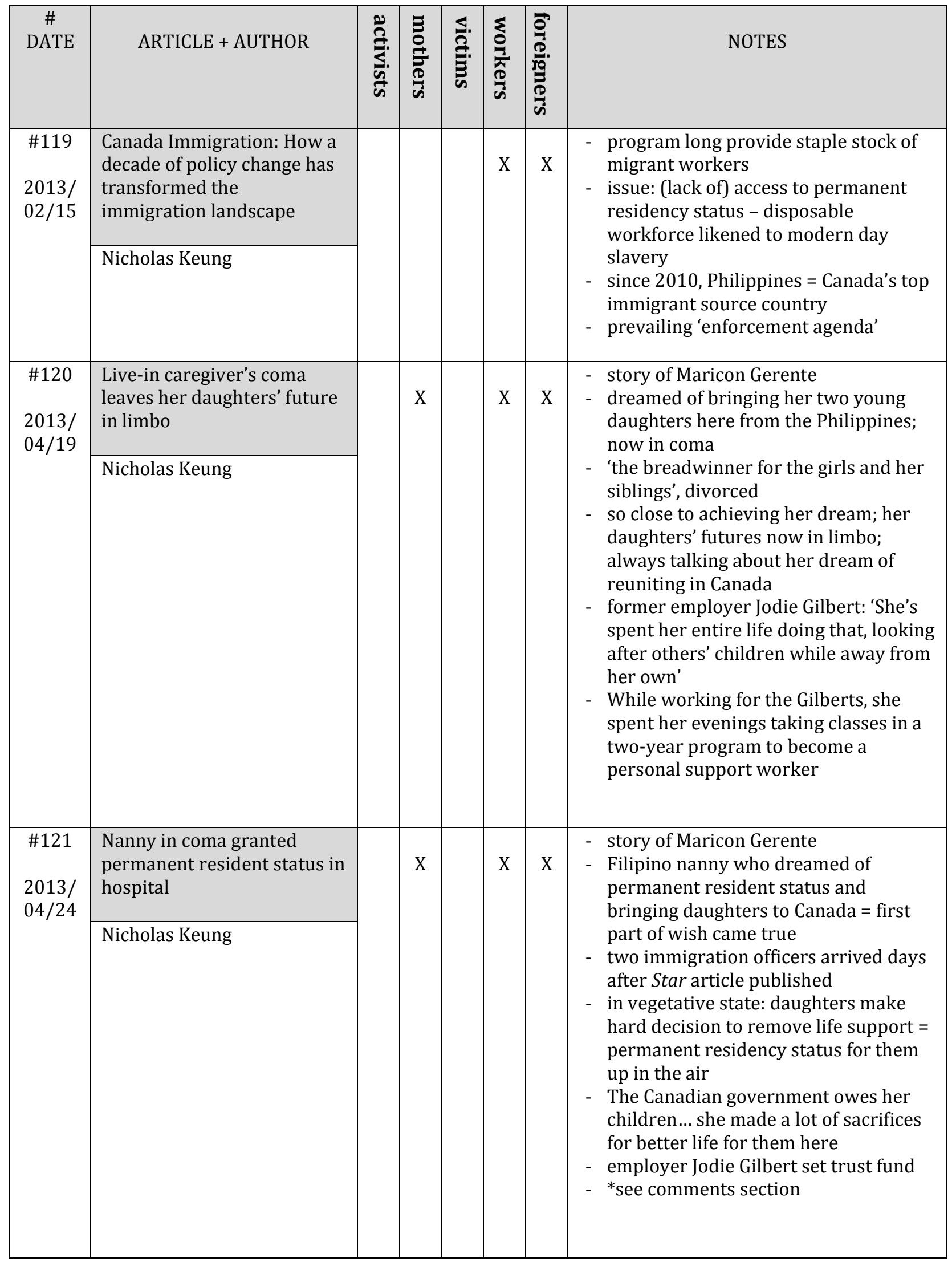




\begin{tabular}{|c|c|c|c|c|c|c|c|}
\hline $\begin{array}{c}\# \\
\text { DATE }\end{array}$ & ARTICLE + AUTHOR & 站. & 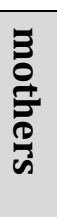 & $\stackrel{\leq}{\stackrel{S}{\Xi}}$ & 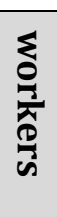 & 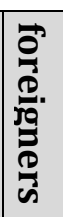 & NOTES \\
\hline \multirow{2}{*}{$\begin{array}{l}122 \\
2013 / \\
04 / 30\end{array}$} & $\begin{array}{l}\text { Reforms to foreign worker } \\
\text { program are 'cosmetic', } \\
\text { workers' advocates say }\end{array}$ & \multirow[t]{2}{*}{$\mathrm{X}$} & & \multirow[t]{2}{*}{$\mathrm{X}$} & \multirow[t]{2}{*}{$\mathrm{X}$} & \multirow[t]{2}{*}{$\mathrm{X}$} & \multirow{2}{*}{$\begin{array}{l}\text { - story of former caregiver Kay Manuel } \\
\text { - 'we are not stealing jobs, but filling } \\
\text { ones Canadians do not want due to } \\
\text { long hours, low pay, and live-in } \\
\text { requirement' } \\
\text { - Ottawa can enhance transparency by } \\
\text { publicizing bad employers }\end{array}$} \\
\hline & Nicholas Keung & & & & & & \\
\hline \multirow[t]{2}{*}{$\begin{array}{l}123 \\
2013 / \\
05 / 31\end{array}$} & $\begin{array}{l}\text { Filipino nanny in coma dies } \\
\text { at } 44 \text {; daughters granted } \\
\text { temporary residency }\end{array}$ & & \multirow[t]{2}{*}{$\mathrm{X}$} & & & \multirow[t]{2}{*}{$\mathrm{X}$} & \multirow{2}{*}{$\begin{array}{l}\text { - story of Maricon Gerente: death } \\
\text { - daughters plan to return to Canada } \\
\text { and apply for permanent residency on } \\
\text { humanitarian grounds } \\
\text { - Filipino nanny; dying wish to reunite } \\
\text { with daughters in Canada } \\
\text { - daughters arrived with help of } \\
\text { Gerente's former employer }\end{array}$} \\
\hline & Nicholas Keung & & & & & & \\
\hline \multirow{2}{*}{$\begin{array}{l}\# 124 \\
2013 / \\
06 / 01\end{array}$} & $\begin{array}{l}\text { Filipino students adjust to } \\
\text { new parents: their own }\end{array}$ & & \multirow[t]{2}{*}{$\mathrm{X}$} & & & \multirow[t]{2}{*}{$\mathrm{X}$} & \multirow{2}{*}{$\begin{array}{l}\text { - } 88 \text { students from Philippines at Forest } \\
\text { Hill Collegiate: many marks lag behind } \\
\text { those even of other newcomers } \\
\text { - } \text { parents eager to show separation and } \\
\text { sacrifice were worth it } \\
\text { - } \quad \text { strength of family bonds; creation of a } \\
\text { generation 'lonely lolas' in Philippines } \\
\text { - children overwhelmed with } \\
\text { expectations and cope by withdrawing } \\
\text { - call on Canada to allow LCP workers to } \\
\text { immigrate with their families } \\
\text { - colonial mentality: get out to get ahead } \\
\text { - torn traditional family asunder }\end{array}$} \\
\hline & Louise Brown & & & & & & \\
\hline \multirow[t]{2}{*}{$\begin{array}{l}\# 125 \\
2013 / \\
07 / 01\end{array}$} & $\begin{array}{l}\text { Immigration law will 'tear } \\
\text { families apart': Live-in } \\
\text { caregivers and refugees will } \\
\text { be the ones hardest hit by } \\
\text { new definition of 'dependent } \\
\text { child' as younger than } 19\end{array}$ & & \multirow[t]{2}{*}{$\mathrm{X}$} & & & \multirow[t]{2}{*}{$\mathrm{X}$} & \multirow{2}{*}{$\begin{array}{l}\text { - story of Lourdes Octaviano Tolentino: } \\
\text { correction made, new law does not } \\
\text { affect her } \\
\text { - by the time LCP worker can apply for } \\
\text { permanent residency, children may be } \\
\text { over the age limit } \\
\text { - 'I don't see a future if I cannot have my } \\
\text { son with me in Canada... kills my } \\
\text { dreams and hopes' } \\
\text { - government: change reflects } \\
\text { immigration goal for economic } \\
\text { prosperity; suggest come as } \\
\text { international students (tuition) } \\
\text { instead } \\
\text { - critics: change will split families, } \\
\text { Canada is a country that honours } \\
\text { family values }\end{array}$} \\
\hline & Nicholas Keung & & & & & & \\
\hline
\end{tabular}




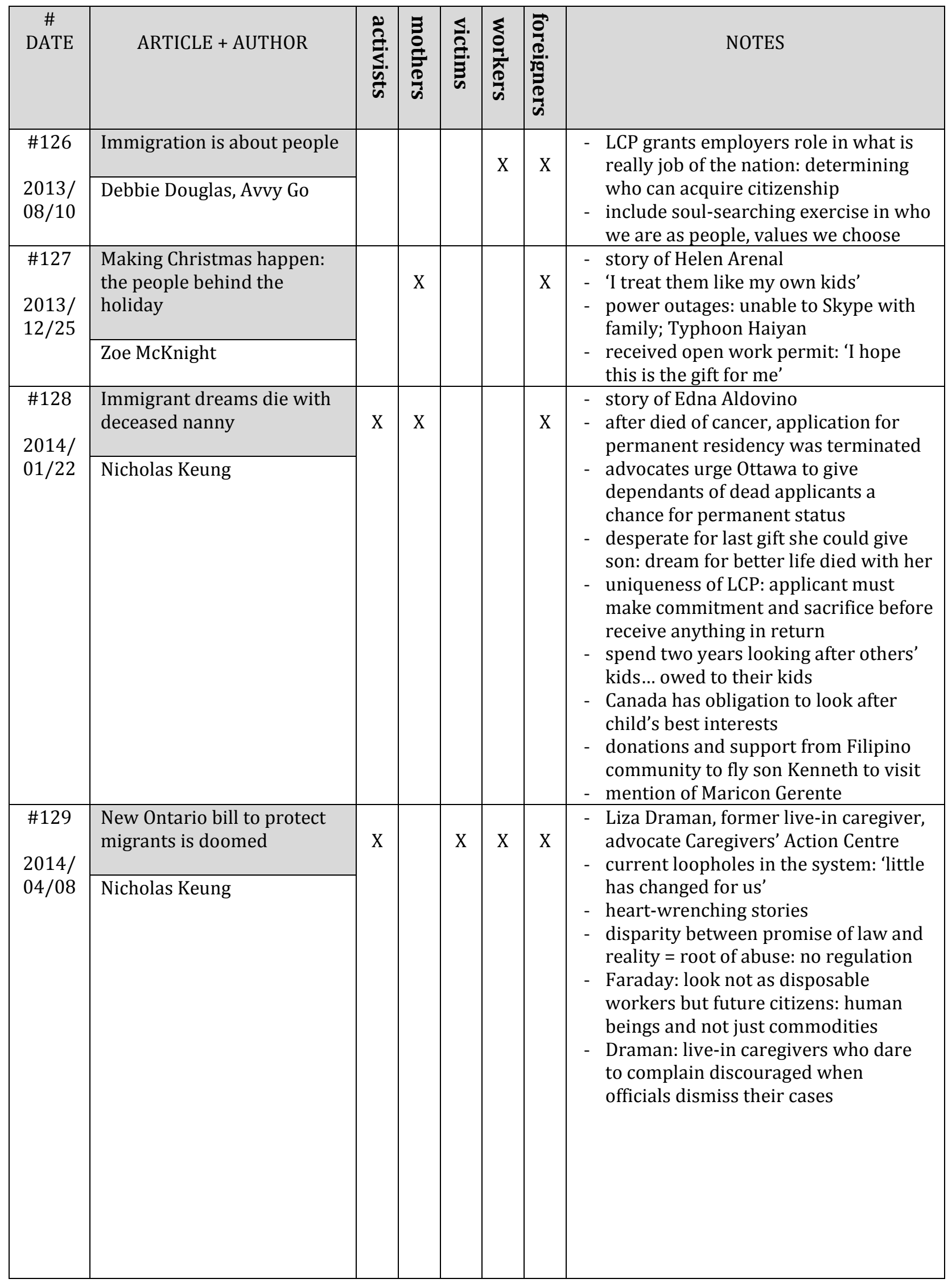




\begin{tabular}{|c|c|c|c|c|c|c|c|}
\hline $\begin{array}{c}\# \\
\text { DATE }\end{array}$ & ARTICLE + AUTHOR & 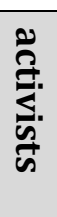 & 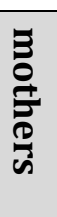 & 㿣. & $\frac{\sum}{O}$ & 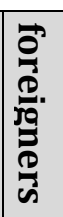 & NOTES \\
\hline \multirow{2}{*}{$\begin{array}{l}\# 130 \\
2014 / \\
05 / 01\end{array}$} & $\begin{array}{l}\text { Temporary foreign workers } \\
\text { a global phenomenon }\end{array}$ & & & & \multirow[t]{2}{*}{$\mathrm{X}$} & \multirow[t]{2}{*}{$\mathrm{X}$} & \multirow{2}{*}{$\begin{array}{l}\text { - vs. Globe column Margaret Wente } \\
\text { - 'are human... dreams and motivation' } \\
\text { - Wente: 'Filipina nannies don't 'move } \\
\text { up the income ladder' } \\
\text { - what's preventing people like nannies } \\
\text { from doing better? } \\
\text { - temporary foreign worker } \\
\text { phenomenon: part of extended } \\
\text { historical conflicts over power } \\
\text { between forces like capital and labour } \\
\text { in which most people didn't even } \\
\text { know they held membership }\end{array}$} \\
\hline & Rick Salutin & & & & & & \\
\hline \multirow{2}{*}{$\begin{array}{c}\# 131 \\
2014 / \\
05 / 19\end{array}$} & $\begin{array}{l}\text { Why Canada rejected these } \\
\text { Typhoon Haiyan victims }\end{array}$ & & \multirow[t]{2}{*}{$\mathrm{X}$} & \multirow[t]{2}{*}{$\mathrm{X}$} & & \multirow[t]{2}{*}{$\mathrm{X}$} & \multirow[b]{2}{*}{$\begin{array}{l}\text { - story of Sharon Creer } \\
\text { - Visa officer not satisfied Toronto } \\
\text { nanny's surviving relatives were } \\
\text { "significantly affected" by Philippines } \\
\text { typhoon: did not have enough money } \\
\text { to support proposed stay in Canada } \\
\text { - Canadian government had announced } \\
\text { it would fast-track visa applications- } \\
\text { government publicity stunt } \\
\text { - Creer, a composed 34-year-old with } \\
\text { kind eyes and strong Christian faith, } \\
\text { tends to keep her emotions in check, } \\
\text { but the past year has shaken her } \\
\text { positive core } \\
\text { - taking care of other people's children } \\
\text { while her own grew up without her } \\
\text { halfway around the world } \\
\text { - Leaving home to make a living is a way } \\
\text { of life in the Philippines } \\
\text { - 'It will be different in Canada, but we } \\
\text { will be together' } \\
\text { - *see comments section }\end{array}$} \\
\hline & Amy Dempsey & & & & & & \\
\hline \multirow[t]{2}{*}{$\begin{array}{c}\text { \#132 } \\
2014 / \\
05 / 27\end{array}$} & $\begin{array}{l}\text { Feds keep details on visas } \\
\text { for typhoon victims secret: } \\
\text { Ministry won't say how } \\
\text { many Filipinos applied for } \\
\text { fast-track status, or how } \\
\text { many were refused }\end{array}$ & & & \multirow[t]{2}{*}{$\mathrm{X}$} & & \multirow[t]{2}{*}{$\mathrm{X}$} & \multirow[t]{2}{*}{$\begin{array}{l}\text { - government: roughly 1,100 cases } \\
\text { approved - Filipinos in Toronto } \\
\text { surprised by high number } \\
\text { - despite urgent situation, some waiting } \\
\text { more than five months for response } \\
\text { - cynicism of government motivations }\end{array}$} \\
\hline & Amy Dempsey & & & & & & \\
\hline
\end{tabular}




\section{REFERENCES}

\section{List of Toronto Star Articles Cited}

Azam, S. (2001, August 28). Who Looks After the Nanny's Children? Toronto Star. Retrieved from http://ezproxy.lib.ryerson.ca/login?url=http://search.proquest.com/docview/438320875.

Bakshe, K. (2008, June 10). Nanny Earned Right to Stay; Re: Dying Nanny Told to Leave Country. Toronto Star. Retrieved from http://www.thestar.com/opinion/2008/06/10/nanny_earned_right_to_stay.print.html.

Brazao, D. (2008, September 22). Nanny Sent to Work as Underpaid Servant. Toronto Star. Retrieved from http://www.thestar.com/news/investigations/2008/09/22/nanny_sent_to_work_as_underp aid_servant.print.html.

Brazao, D. (2009a, April 27). Ontario’s ‘Nanny Hotline’ Goes Live. Toronto Star. Retrieved from http://www.thestar.com/life/health_wellness/2009/04/27/ontarios_nanny_hotline_goes_liv e.print.html.

Brazao, D. (2009b, May 5). Ruby Dhalla's Nanny Trouble. Toronto Star. Retrieved from http://www.thestar.com/news/investigations/2009/05/05/ruby_dhallas_nanny_trouble.pri nt.html.

Brazao, D. (2009c, October 21). Exploited Nannies Win Fee Battle. Toronto Star. Retrieved from http://www.thestar.com/news/investigations/2009/10/21/exploited_nannies_win_fee_battl e.print.html. 
Brazao, D. \& Cribb, R. (2009a, March 14). Nannies Trapped in Bogus Jobs. Toronto Star. Retrieved from http://www.thestar.com/news/investigations/2009/03/14/nannies_trapped_in_bogus_jobs. print.html.

Brazao, D. \& Cribb, R. (2009b, April 3). Years of Championing Caregivers' Cause Pays Off. Toronto Star. Retrieved from http://www.thestar.com/life/health_wellness/2009/04/03/years_of_championing_caregiver s_cause_pays_off.print.html.

Brown, L. (2013, June 1). Filipino Students Adjust to New Parents - Their Own. Toronto Star. Retrieved from http://www.thestar.com/gta/2013/06/01/filipino_students_adjust_to_new_parents_their_o wn.html.

Cohn, M. R. (2009, May 12). Nannygate and the Global Economy. Toronto Star. Retrieved from http://www.thestar.com/opinion/2009/05/12/nannygate_and_the_global_economy.print.html.

Crawford, T. (2009, February 28). Why It's Bad to Cheat the Nanny. Toronto Star. Retrieved from http://www.thestar.com/life/parent/2009/02/28/why_its_bad_to_cheat_the_nanny.print.html.

Cribb, R. (2009, April 6). Filipinos Celebrate Nannies' Triumph; Rally Turns into Party for Proposed Law to Protect Caregivers. Toronto Star. Retrieved from http://ezproxy.lib.ryerson.ca/login?url=http://search.proquest.com/docview/439576651.

Fabregas, R. (2010, October 8). Back to the Future for Caregivers. Toronto Star. Retrieved from http://www.thestar.com/opinion/editorialopinion/2010/10/08/back_to_the_future_for_car egivers.print.html. 
Flavelle, D. (1989, February 11). Finding the Perfect Nanny. Toronto Star. Retrieved from http://ezproxy.lib.ryerson.ca/login?url=http://search.proquest.com/docview/435872690.

Hall, J. (1992, April 20). Ottawa Defends Policy on Domestic Workers. Toronto Star. Retrieved from http://ezproxy.lib.ryerson.ca/login?url=http://search.proquest.com/docview/436612269.

Hynes, L. (2009, March 21). More Voices on Nanny Series. Toronto Star. Retrieved from http://www.thestar.com/opinion/2009/03/21/more_voices_on_nanny_series.print.html.

Kamel, D. (2008, August 26). Dying Nanny Wants Law Change. Toronto Star. Retrieved from http://www.thestar.com/news/gta/2008/08/26/dying_nanny_wants_law_change.print.html.

Keung, N. (2007, March 2). 'Falling Through the Cracks': Cancer Threatens Nanny's Life and Permanent Status. Toronto Star. Retrieved from http://search.proquest.com/docview/439167597/fulltext/55A32AF721194543PQ/13.

Keung, N. (2008a, July 19). Nanny Battling Terminal Cancer Gets Reprieve. Toronto Star. Retrieved from http://www.thestar.com/news/gta/2008/07/19/nanny_battling_terminal_cancer_gets_repri eve.print.html.

Keung, N. (2008b, December 28). Ill Nanny Inspires Push for Reform. Toronto Star. Retrieved from http://www.thestar.com/news/2008/12/28/ill_nanny_inspires_push_for_reform.print.html.

Keung, N. (2009a, March 8). Nanny Back in Hospital as Her Cancer Worsens. Toronto Star. Retrieved from http://www.thestar.com/news/gta/2009/03/08/nanny_back_in_hospital_as_her_cancer_wo rsens.print.html. 
Keung, N. (2009b, March 11). Juana Tejada, 39: Nanny Inspired Reforms for Caregivers. Toronto Star. Retrieved from http://www.thestar.com/news/gta/2009/03/11/juana_tejada_39_nanny_inspired_reforms_f or_caregivers.print.html.

Keung, N. (2011a, April 25). Labour Scholarship Empowers Canadian Migrant Workers. Toronto Star. Retrieved from http://www.thestar.com/news/investigations/2011/04/25/labour_scholarship_empowers_ canadian_migrant_workers.print.html.

Keung, N. (2011b, November 16). TV Drama Focuses on 'Canada's Most Celebrated Caregiver'. Toronto Star. Retrieved from http://www.thestar.com/news/gta/2011/11/16/tv drama focuses on canadas most celebr ated caregiver.print.html.

Keung, N. (2013a, February 15). Canadian Immigration: How a Decade of Policy Change Has Transformed the Immigration Landscape. Toronto Star. Retrieved from http://www.thestar.com/news/immigration/2013/02/15/canada_immigration_how_a_deca de_of_policy_change_has_transformed_the_immigration_landscape.print.html.

Keung, N. (2013b, May 31. Filipino Nanny in Coma Dies at 44; Daughters Granted Temporary Residency. Toronto Star. Retrieved from http://www.thestar.com/news/gta/2013/05/31/filipino_nanny_in_coma_dies_at_44_daught ers_granted_temporary_residency.print.html.

Keung, N. (2014, January 22). Immigrant Dreams Die with the Deceased Nannies. Toronto Star. Retrieved from 
http://www.thestar.com/news/immigration/01/22/immigrant_dreams_die_with_deceased_ nannies.print.html.

Monsebraaten, L. (2009, November 2). Nannies' Dreams Choked by Bureaucratic Red Tape. Toronto Star. Retrieved from http://www.thestar.com/news/investigations/2009/11/02/nannies_dreams_choked_by_bur eaucratic_red_tape.print.html.

Nangwaya, A. (2009, April 7). Correcting Flaws in Nanny System. Toronto Star. Retrieved from http://www.thestar.com/opinion/2009/04/07/correcting_flaws_in_nanny_system.print.html.

Oakland, R. (2002, July 21). Sending Money Home is Big Business. Toronto Star. Retrieved from http://ezproxy.lib.ryerson.ca/login?url=http://search.proquest.com/docview/438457251.

Ponting, J. (2009, March 21). More Voices on Nanny Series. Toronto Star. Retrieved from http://www.thestar.com/opinion/2009/03/21/more_voices_on_nanny_series.print.html.

Quarta, L. (1995, June 27). Foreign Nanny No Daycare Solution. Toronto Star. Retrieved from http://ezproxy.lib.ryerson.ca/login?url=http://search.proquest.com/docview/437269164.

Smith, D. (2012, January 6). Nanny Nation: From the Philippines, with Love. Toronto Star. Retrieved from http://www.thestar.com/news/insight/2012/01/06/nanny_nation_from_the_philippines_wi th_love.print.html.

Taylor L. C. (2009a, January 2). High Cost of Looking After Others' Kids. Toronto Star. Retrieved from http://www.thestar.com/life/health_wellness/2009/01/03/high_cost_of_looking_after_other s_kids.print.html. 
Taylor, L. C. (2009b, April 9). Job Bank Could End Rogue Fees for Nannies. Toronto Star. Retrieved from

http://ezproxy.lib.ryerson.ca/login?url=http://search.proquest.com/docview/439564296.

Taylor, L. C. \& Keung, N. (2008, October 24). New Criteria Alarm Immigrants; Radical Changes to Immigration Process are Dangerous, Say Some Educated Newcomers. Toronto Star. Retrieved from

http://ezproxy.lib.ryerson.ca/login?url=http://search.proquest.com/docview/439494640.

Tesher, E. (1996, October 16). Foreign Domestics Need Our Help. Toronto Star. Retrieved from http://search.proquest.com/docview/4375591317.

Tesher, E. (2002, April 25). Caregivers Have Made a Difference. Toronto Star. Retrieved from http://ezproxy.lib.ryerson.ca/login?url=http://search.proquest.com/docview/438429639.

Waldman, L. (2009, May 18). The Exploitation of Nannies Has a Long, Dreary History. Toronto Star. Retrieved from http://www.thestar.com/opinion/columnists/2009/05/18/the_exploitation_of_nannies_has_ a_long_dreary_history.print.html.

Walkom, T. (2009, May 16). The Real Moral of Nannygate. Toronto Star. Retrieved from http://www.thestar.com/news/insight/2009/05/16/the_real_moral_of_nannygate.print.html.

\section{Academic References}

Althusser, L. (1970). Ideology and Ideological State Apparatuses (Notes Toward an Investigation). In L. Althusser (Ed.), Lenin and Philosophy and Other Essays (B. Brewster, Trans.). London: New Left Books. (Original work published in 1970) 
Arat-Koç, S. (2001). Caregivers Break the Silence: A Participatory Action Research on the Abuse and Violence, including the Impact of Family Separation, Experienced by Women in the Live-In Caregiver Program. Toronto: INTERCEDE.

Baldoz, R. (2011). The Third Asiatic Invasion: Migration and Empire in Filipino America, 1898-1946. New York: New York University Press.

Barber, P. G. (2008). The Ideal Immigrant? Gendered Class Subjects in Philippine-Canada Migration. In Third World Quarterly, 29, 1265-1285.

Bauder, H. (2008). Foreign Farm Workers in Ontario (Canada): Exclusionary Discourse in the Newsprint Media. Journal of Peasant Studies, 35(1), 100-118.

Bonifacio, G. T. (2013). Pinay on the Prairies: Filipino Women and Transnational Identities. Vancouver: UBC Press.

Brickner, R. K. and Straehle, C. (2010). The Missing Link: Gender, Immigration Policy and the Live-in Caregiver Program in Canada. In Policy and Society, 29, 309-320.

Catungal, J. P. (2012). Scales of Violence from the Body to the Globe: Slain Filipino Youth in Canadian Cities. In R. S. Coloma, B. McElhinny, E. Tungohan, J. P. Catungal, L. M. Davidson (Eds.), Filipinos in Canada: Disturbing Invisibility (pp. 321-340). Toronto: University of Toronto Press.

Citizenship and Immigration Canada. (2013). Facts and Figures 2012 - Immigration Overview: Permanent and Temporary Residents. Retrieved from http://www.cic.gc.ca/english/resources/statistics/facts2012/permanent/03.asp. 
Citizenship and Immigration Canada. (2014). Live-in Caregivers. http://www.cic.gc.ca/ENGLISH/work/caregiver/index.asp.

Cohen, R. (2000). 'Mom is a Stranger': The Negative Impact of Immigration Policies on the Family Life of Filipina Domestic Workers. In Ethnic Studies, 32(3), 76-88.

Coloma, R. S., McElhinny, B., Tungohan, E., Catungal, J. P., \& Davidson, L. M. (2012). Filipinos in Canada: Disturbing Invisibility. Toronto: University of Toronto Press.

Connell, R. (2007). Southern Theory: The Global Dynamics of Knowledge in Social Science. Cambridge: Polity Press.

Cristaldi, F. \& Darden, J. T. (2011). The Impact of Immigration Policies on Transnational Filipino Immigrant Women: A Comparison of Their Social and Spatial Incorporation in Rome and Toronto. In Journal of Urban History, 37(5), 694-709.

Daenzer, P. M. (1997). An Affair Between Nations: International Relations and the Movement of Household Service Workers. In A.B. Bakan \& D. S. Stasiulis (Eds.), Not One of the Family: Foreign Domestic Workers in Canada (81-118). Toronto: University of Toronto Incorporated.

Davidson, L. M. (2012). (Res)entiment and Practices of Hope: The Labours of Filipina LiveIn Caregivers in Filipino Canadian Families. In R. S. Coloma, B. McElhinny, E. Tungohan, J. P. Catungal, L. M. Davidson (Eds.), Filipinos in Canada: Disturbing Invisibility (142-160). Roland Sintos Coloma et al, eds. Toronto: University of Toronto Press. 
Edejer, H. (2013). Politicizing Pigmentation and Privilege: Idealizations of Whiteness and Feminine Beauty in Postcolonial Contexts. Unpublished term paper.

Edejer, H. (2014). Literature Review of the Live-In Caregiver Program and Narratives of its Workers. Unpublished term paper.

Fairclough, N.L. \& Wodak, R. (1997). Critical Discourse Analysis. In T.A. van Dijk (Ed.), Discourse Studies: A Multidisciplinary Introduction, Vol. 2. Discourse as Social Interaction (258-284). London: SAGE Publications.

Fudge, J. (1997). Little Victories and Big Defeats: The Rise and Fall of Collective Bargaining Rights for Domestic Workers in Ontario. In A.B. Bakan \& D. S. Stasiulis (Eds.), Not One of the Family: Foreign Domestic Workers in Canada (119-146). Toronto: University of Toronto Incorporated.

Hall, S. (1997). Representation \& the Media [Lecture Transcript]. Retrieved from Media Education Foundation site: http://www.mediaed.org/assets/products/409/transcript_409.pdf.

Hall, S. (2007). The West and the Rest: Discourse and Power. In T. Das Gupta, C. E. James, R. C. A. Maaka, G.-E. Galabuzi, C. Andersen (Eds.), Race and Racialization: Essential Readings (56-60). Toronto: Canadian Scholars' Press Inc. (Original work published in 1996)

Hart, C. (2013). Argumentation Meets Adapted Cognition: Manipulation in Media Discourse on Immigration. In Journal of Pragmatics, 59, 200-209. 
Kelly, P. (2006). Filipinos in Canada: Economic Dimensions of Immigration and Settlement. In M. J. Doucet (Ed.), CERIS Working Paper No. 48. Toronto: Joint Centre of Excellence for Research on Immigration and Settlement.

Kelly, P. \& Lusis, T. (2006). Migration and the Transnational Habitus: Evidence from Canada and the Philippines." In Environment and Planning A, 38, 831-847.

Kelly, P., Park, S., de Leon, C., \& Priest, J. (2011). Profile of Live-In Caregiver Immigrants to Canada, 1993-2009. TIEDI Analytical Report 18. Toronto Immigrant Employment Data Initiative.

Lan, P.-C. (2003). Maid or Madam? Filipina Migrant Workers and the Continuity of Domestic Labour. In Gender and Society, 17(2), 187-208.

Lee, E. and Johnstone, M. (2013). Global Inequities: A Gender-Based Analysis of the Live-In Caregiver Program and the Kirogi Phenomenon in Canada. In Journal of Women and Social Work, 28(4), 401-414.

Lindio-McGovern, L. (2012). Circuits of the Commodification of Filipino Domestic Workers in the Labor Export Web of Globalization. In Globalization, Labor Export and Resistance (23-42). New York: Routledge.

Lutz, Helma. (2011). The New Maids: Transnational Women and the Care Economy. (D. Shannon, Trans.). New York: Zed Books. (Original work published 2011)

Macklin, A. (1994). On the Inside Looking In: Foreign Domestic Workers in Canada. In W. Giles \& S. Arat-Koç (Eds.), Maid in the Market: Women's Paid Domestic Labour (13-39). Halifax: Fernwood Publishing. 
Nakano Glenn, E. (1992). From Servitude to Service Work: The Historical Continuities of Women's Paid and Unpaid Reproductive Labour. Signs: Journal of Women and Culture and Society, 18(1), 1-44.

Neuman, W.L. (2004). Basics of Social Research: Qualitative and Quantitative Approaches. Boston, MA: Pearson.

Ogaya, C. (2004). Social Discourses on Filipino Women Migrants. In Feminist Review, 77, 180-182.

--- (2006). Towards an Analysis of Social Mobility of Transnational Migrant Women: The Case of Filipina Domestic Workers. In A. Agrawal, (Ed.), Women and Migration in Asia, Volume 4 Migrant Women at Work. Thousand Oaks: SAGE Publications.

Pagaduan, M. C. (2006). Leaving Home: Filipino Women Surviving Migration. In S. Arya \& A. Roy (Eds.), Women and Migration in Asia: Volume 2 Poverty, Gender and Migration.. Thousand Oaks: SAGE Publications Inc.

Parreñas, R. S. (2006). Caring for the Filipino Family: How Gender Differentiates the Economic Causes of Labour Migration. In A. Agrawal (Ed.), Women and Migration in Asia, Volume 4 Migrant Women at Work. Thousand Oaks: SAGE Publications, 2006.

---. (2001). Servants of Globalization: Women, Migration, and Domestic Work. Stanford: Stanford University Press.

Philippine Women Centre of B.C. (2000). Canada: The New Frontier for Filipino Mail-Order Brides. Ottawa, Status of Women Canada.

Pratt, G. (2009). Circulating Sadness: Witnessing Filipina Mothers' Stories of Family Separation. In Gender, Place and Culture, 16(1), 3-22. 
---. (2012). Families Apart: Migrant Mothers and the Conflicts of Labor and Love.

Minneapolis: University of Minnesota Press.

Schecter, T. (1998). Race, Class, Women and the State: The Case of Domestic Labour in

Canada. Montreal: Black Rose Books.

Spitzer, D. \& Torres, S. (2008). Gender-Based Barriers to Settlement and Integration for

Live-In-Caregivers: A Review of the Literature. In M. J. Doucet (Ed.), CERIS Working

Paper No. 71. Toronto: Joint Centre of Excellence for Research on Immigration and

Settlement.

Teelucksingh, C., \& Galabuzi, G.-E. (2005). Impact of Race and Immigrants Status on

Employment Opportunities and Outcomes in the Canadian Labour Market. In S. Enoch

(Ed.), CERIS Working Paper No. 22. Toronto: Joint Centre of Excellence for Research on Immigration and Settlement.

Tung, C. (2000). The Cost of Caring: The Social Reproductive Labour of Filipina Live-In Home Health Caregivers. In Frontiers: A Journal of Women's Studies, 21(1), 61-82.

Tungohan, E. (2012). Debunking Notions of Migrant 'Victimhood': A Critical Assessment of Temporary Labour Migration Programs and Filipina Migrant Activism in Canada. In R. S. Coloma, B. McElhinny, E. Tungohan, J. P. Catungal, L. M. Davidson (Eds.), Filipinos in Canada: Disturbing Invisibility, (161-180). Toronto: University of Toronto Press.

Ty, E. (2012). Filipino Canadians in the Twenty-First Century: The Politics of Recognition in a Transnational Affect Economy. In R. S. Coloma, B. McElhinny, E. Tungohan, J. P. Catungal, L. M. Davidson (Eds.), Filipinos in Canada: Disturbing Invisibility (46-67). Toronto: University of Toronto Press. 
Urbano, Ryan. (2012). Global Justice and the Plight of Filipino Domestic Migrant Workers. In Journal of Asian and African Studies, 47(6), 605-619.

Van Dijk, T. (1988). News Analysis: Case Studies of International and National News in the Press. New Jersey: Lawrence Erlbaum Associates, 1988.

Van Dijk, T. (2008). Discourse \& Power. New York: Palgrave Macmillan.

Velasco, P. M. (1997). 'We Can Still Fight Back': Organizing Domestic Workers in Toronto. In A.B. Bakan \& D. S. Stasiulis (Eds.), Not One of the Family: Foreign Domestic Workers in Canada, 157-164. Toronto: University of Toronto Incorporated, 1997. 